\title{
Los centros residenciales para personas mayores, especial referencia a Andalucía
}

\author{
Severiano Fernández Ramos \\ Profesor Titular de Derecho Administrativo \\ Universidad de Cádiz
}

SUMARIO: 1. INTRODUCCIÓN: DE LA SUBSIDIARIEDAD A LA RESPONSABILIDAD PÚBLICA. 1.1. La atención tradicional de las personas mayores: apoyo informal y principio de subsidiariedad. 1.2. El fenómeno del envejecimiento de la población y la crisis del apoyo informal. 2. LOS CENTROS RESIDENCIALES PARA PERSONAS MAYORES EN EL MARCO DEL SISTEMA DE SERVICIOS SOCIALES. 2.1. La legislación autonómica sobre servicios sociales para personas mayores. 2.2. El sector de centros residenciales para personas mayores. 2.2.1. $\mathrm{Ca}$ racterización y tipología de los centros residenciales para personas mayores. 2.2.2. Estructura del sector de los centros residenciales para mayores. 2.3. Régimen común a todos los centros residenciales para personas mayores. 2.3.1. Demora en la reglamentación y tolerancia en la adaptación a la misma. 2.3.2. Requisitos materiales y funcionales de los centros residenciales para personas mayores. 2.3.3. El reglamento de régimen interior de los centros. 2.3.4. Los derechos de los usuarios de los centros. 2.3.5. Régimen de autorización de los centros. 2.3.6. Gestión de la calidad. 2.4. Régimen de los centros públicos. 2.4.1. Aspectos generales. 2.4.2. Contribución de los usuarios a la financiación de los servicios. 2.4.3. Participación de los usuarios en el funcionamiento de los centros. 2.5. Régimen de los centros concertados. 2.5.1. Entidades e instrumentos para la concertación de servicios. 2.5.2. La acreditación como requisito previo. 2.5.3. Financiación de los centros concertados 2.5.4. Posición de los usuarios de centros concertados. 2.5.5. Relaciones Administración - centro concertado. 2.6. Los centros privados no concertados. 2.7. La insuficiente y desigual cobertura de los sistemas públicos de servicios sociales y sus consecuencias. 2.7.1. Las (interminables) listas de espera. 2.7.2. Los criterios de admisión: el muro de los baremos. 2.7.3. La aplicación de los baremos. 2.7.4. El caso especial de los ingresos de urgencia social. 2.7.5. Los problemas de movilidad en el conjunto del territorio español. 3. LA RESPONSABILIDAD SANCIONADORA EN MATERIA DE RESIDENCIAS PARA PERSONAS MAYORES. 3.1. La inspección administrativa de residencias para personas mayores. 3.2. El régimen sancionador. 3.3. La proliferación de centros clandestinos. 4. LAS RESIDENCIAS PARA PERSONAS MAYORES EN EL NUEVO SISTEMA DE ATENCIÓN A LA DEPENDENCIA. 4.1. Aspectos generales del Sistema para la Autonomía y Atención de la Dependencia 4.2. Determinaciones específicas sobre los centros residenciales para mayores. 4.3. La responsabilidad sancionadora en la Ley 39/2006 del Sistema para la Autonomía y Atención a Dependencia. BIBLIOGRAFIA Y DOCUMENTACIÓN. 


\section{INTRODUCGIÓN: DE LA SUBSIDIARIEDAD A LA RESPONSA- BILIDAD PÚBLICA}

\subsection{La atención tradicional de las personas mayores: apoyo informal y princi- pio de subsidiariedad}

Como es sobradamente conocido, en nuestro país la atención y cuidado de los más ancianos ha recaído tradicionalmente sobre la familia (y de manera especial sobre las mujeres). Ello ha sido posible gracias principalmente a dos circunstancias: de un lado, hasta fechas bien recientes el número de personas mayores de 80 años que precisaran de cuidados continuados era relativamente reducido; $y$, de otro lado, el modo de convivencia predominante era el de la familia extensa, un contexto en el que casi siempre existía la figura de la "madre de todos", esto es la mujer cuyo rol consistía fundamentalmente en una plena dedicación personal y vital a la atención de su casa y al cuidado de todos los miembros de la familia. De este modo, la función de atención y cuidados de personas mayores se ha venido satisfaciendo en su inmensa mayoría mediante el llamado "apoyo informal", constituido por familiares y allegados ${ }^{1}$.

En este contexto social, la Administración sólo entraba en escena de un modo subsidiario, esto es cuando ocurría una situación de necesidad grave: caso de ancianos indigentes o sin familia. Lo habitual era, por tanto, que los cuidados se prestasen dentro del marco familiar y sólo si éste era inexistente o fallaba, intervenían los sistemas formales de atención, previa prueba de escasez de medios económicos, requisito éste característico de la asistencia social ${ }^{2}$. A lo cual debe sumarse la acentuada dispersión no ya física sino conceptual de los recursos institucionales existentes en esta época ${ }^{3}$.

\footnotetext{
${ }^{1}$ Vid. Comisión de Sanidad y Asuntos Sociales del Senado, "Ponencia especial para el estudio de la problemática del envejecimiento de la población española", BOCG, Senado, Serie I, 17.12.1999, núm. 805. Todavía en relación con el año 2002 el Defensor del Pueblo señalaba: "La atención a los mayores sigue siendo, en nuestro país, un asunto esencialmente familiar y de forma significativa de las mujeres: el 32 por 100 de los mayores dependientes están al cuidado de una de sus hijas y un 6 por 100 al de los hijos, mientras el Estado sólo atiende al 7 por 100" (Informe a las Cortes Generales 2002, p. 378).

${ }^{2}$ Vid. M. ALONSO OLEA- J.L. TORTUERO PLAZA, Instituciones de Seguridad Social, 13aㅡ ed., Civitas, 1992, p. 568.

${ }^{3}$ Así, la Administración del Estado aún mantiene residencias para ancianos dependientes de la vetusta Dirección General de Beneficencia y del Auxilio Social, pero al mismo tiempo crea residencias desde la Seguridad Social, mediante el llamado "Servicio de Asistencia a Pensionistas",
} 


\subsection{El fenómeno del envejecimiento de la población y la crisis del apoyo in- formal}

Sin embargo, desde la década de los 80 es notorio el fenómeno del envejecimiento de la población y, sobre todo, una característica fundamental de la población anciana y que, según las proyecciones demográficas previstas, se irá agudizando con el paso del tiempo, es la que se ha llamado "envejecimiento del envejecimiento", o sobre-envejecimiento, esto es, el gran aumento que está experimentando el colectivo de población de 80 y más años (también denominado "cuarta edad"), cuyo ritmo de crecimiento será en el futuro muy superior al del grupo de 65 y más años en su conjunto ${ }^{4}$.

Sucede, no obstante, que el apoyo informal, como medio ordinario de atención de estas personas está en crisis, por varias razones. Primero, y sobre todo, por que cada vez existen menos mujeres en edad y disponibilidad de cuidar y más ancianos/as que precisan cuidados de larga duración, y esta brecha se incrementa con el paso de los años. Circunstancia a la que se suman las grandes transformaciones ocurridas en los modelos de familia ${ }^{5}$.

después denominado "Servicio social de la tercera edad", hasta su integración en 1979 en el INSERSO. Pero, además, la Ley de Régimen Local de 1955 -art. 245- declaraba, entre las obligaciones mínimas de las Provincias, la instalación y sostenimiento de un Hogar de Ancianos y desvalidos, añadiendo -art. 250.1- que las Diputaciones Provinciales estaban obligadas "a recluir en el Hogar de Ancianos y desvalidos a los indigentes nacidos en la Provincia o cuyo lugar de naturaleza no sea conocido", o que residan en la misma durante dos años al menos -art. 250.4-. Vid, sobre este confuso panorama institucional, J.L. BELTRÁN AGUIRRE, El régimen jurídico de la acción social pública, IVAP, Oñati, 1992, p. 100.

${ }^{4}$ El fenómeno demográfico se funda en dos datos notorios: el descenso de la fecundidad -en cifra muy por debajo del reemplazo generacional, 2,1 hijos por mujer-, y el aumento de la supervivencia de las personas de más edad, y la concurrencia de ambos factores ha dado pie a algunos a hablar de un futuro "hongo poblacional", en lugar de "pirámide poblacional" -Defensor del Pueblo Andaluz, Informe al Parlamento de Andalucía 1999, p. 802-. En España la población de 65 y más años en el año 2000 era de 6,6 millones de personas, un 16,6\% de la población total, pero tan solo seis años después, a 1 de enero de 2006, ascendió 7.477.761 de personas, representando el 16,8\% de la población total. Observatorio de Personas Mayores, Informe 2006, Las personas mayores en España, IMSERSO, 2006, p. 369. Asimismo, según un informe presentado por el Ministerio de Trabajo y Asuntos Sociales, en la II Asamblea Mundial sobre el Envejecimiento, celebrada en Madrid en el 2001, la edad media en que se inicia la dependencia y la necesidad de ayuda, se sitúa en nuestro país en torno a los setenta y dos años y, a partir de los setenta y cinco años casi la mitad de la población tiene problemas en algunas actividades diarias básicas, que para uno de cada cinco son graves.

${ }^{5}$ Entre otras, pérdida de su concepción como institución permanente (incremento del número de separaciones, divorcios y nuevos matrimonios); movilidad geográfica de los distintos 
En este contexto de la llamada "crisis de los cuidadores informales", el viejo principio de subsidiariedad de la Administración es manifiestamente inadecuado para la actual estructura social y las nuevas necesidades, pues será -está siendo ya- literalmente imposible para muchas familias asumir todo el cuidado a sus expensas, mucho menos si éste se encuentra a cargo de una sola persona. La familia de la persona mayor podrá continuar satisfaciendo sus necesidades de apoyo emocional o informativo, pero con frecuencia resultará imposible asumir a su exclusivo cargo el apoyo material. Por tanto, urge que desde los poderes públicos se articule una política de atención y protección de las personas mayores dependientes en la que sin pretender sustituir por completo a la familia, sí al menos se ofrezca servicios para apoyarla y complementarla ${ }^{6}$.

No es necesario recordar, además, que la población anciana, en general, dispone de los menores niveles de renta, pues una mayoría muy elevada se desenvuelve económicamente con los valores de las pensiones mínimas, e incluso, un amplio colectivo subsiste con las exiguas rentas de las pensiones no contributivas. La precariedad de las pensiones públicas conlleva que el envejecimiento represente, desde el punto de vista económico, un motivo de empobrecimiento de las personas que superan los sesenta y cinco años de $\operatorname{edad}^{7}$.

\section{LOS CENTROS RESIDENCIALES PARA PERSONAS MAYORES EN EL MARCO DEL SISTEMA DE SERVICIOS SOCIALES}

\subsection{La legislación autonómica sobre servicios sociales para personas mayores}

Curiosamente, la Constitución de 1978 se anticipó varias décadas al problema actualmente planteado a la sociedad española, al establecer -art. 50-:

miembros de la familia (por estudios o cambios de trabajo); permanencia de los hijos/as en la casa familiar hasta edades que llegan a superar los 30 años; $y$, sobre todo, la progresiva incorporación de la mujer al mundo del trabajo retribuido y al conjunto de las instituciones sociales. Ni que decir tiene que todo esto no tiene nada de novedoso, y que las instituciones vienen estudiando estos cambios sociales desde hace muchos años. Vid. Por ejemplo, el Informe extraordinario "Situación de los ancianos en Galicia”, de junio 1994, del Valedor do Pobo.

${ }^{6}$ Defensor del Pueblo, Informe a las Cortes Generales 2002, p. 378. Ya la Resolución sobre las ayudas a ancianos en la Comunidad Europea de 1986, aprobada por el PE, señalaba que los familiares deben ser apoyados en sus cuidados mediante una amplia oferta de asistencia a domicilio.

7 "La tercera edad resume, acentuándolas, todas las desigualdades sociales, ya que la vejez depende de lo que ha sido la vida activa, y las privaciones, las preocupaciones y la pobreza ayudan a envejecer". Vid. Defensor del Pueblo Andaluz, Informe al Parlamento de Andalucía 1996, p. 85. 
"Los poderes públicos garantizarán, mediante pensiones adecuadas y periódicamente actualizadas, la suficiencia económica a los ciudadanos durante la tercera edad. Asimismo, y con independencia de las obligaciones familiares, promoverán su bienestar mediante un sistema de servicios sociales que atenderán sus problemas específicos de salud, vivienda, cultura y ocio" 8 .

Ahora bien, según el bloque de la constitucionalidad (Constitución y Estatutos de Autonomía), las competencias en materia de servicios sociales, en sentido estricto, corresponden, en principio en exclusiva, a las Comunidades Autónomas ${ }^{9}$. No obstante, dado el carácter integral de las actuaciones públicas en materia de promoción y protección de las personas mayores, la Administración del Estado ha venido aprobando diversas iniciativas, auspiciadas desde instancias internacionales, entre las que deben destacarse el Plan Gerontológico Estatal 1992-2000 ${ }^{10}$ y el Plan de Acción para las Personas Mayores 2003-200711.

\footnotetext{
${ }^{8}$ Como ha señalado J. TORNOS MAS - Los servicios sociales de atención a la tercera edad. El caso de Cataluña, Tirant lo Blanch, Valencia, 2002, p. 18-, en la referencia de la Constitución a un "sistema" está implícita la exigencia de una estructura pública que garantice a las personas mayores la atención de sus problemas específicos.
}

${ }^{9}$ No obstante, debe señalarse que determinados centros para la tercera edad dependientes del entonces INSERSO fueron transferidos a las Comunidades Autónomas como parte de la competencia no ya exclusiva sino ejecutiva en materia de gestión de las prestaciones y servicios de la Seguridad Social. Sobre los servicios sociales como un sistema de protección social distinto a las Seguridad Social, y la delimitación de competencias entre Estado y Comunidades Autónomas, vid. A. GARCÉS SANAGUSTÍN, Las prestaciones económicas en el ámbito de la protección asistencial, Cedecs, Barcelona, 1996, pp. 20 y 22; J.L. BELTRÁN AGUIRRE, "Los servicios sociales”, RVAP núm. 57, 2000; J. PEMÁN GAVÍN, "Sobre el concepto constitucional de asistencia social", RAP núm. 161, 2003, pp. 239 y ss.; M. MORENO REBATO, Régimen jurídico de la Asistencia Social, MTAS, 2002; M. VAQUER CABALLERÍA, La acción social, Tirant lo Blanch, Valencia, 2002.

${ }^{10}$ El Plan Gerontológico Estatal 1992-2000 se puso en marcha como la primera iniciativa general para afrontar las consecuencias del envejecimiento en España. Entre sus objetivos, destacaba el lograr el acercamiento de los servicios sociosanitarios a los mayores, dentro de un marco sectorial, para lo cual se proponía diseñar un mapa de áreas en el que se integren y coordinen los referidos servicios.

${ }^{11}$ Aprobado por el Consejo de Ministros el 29 de agosto de 2003, de nuevo formula entre sus estrategias avanzar hacia una atención coordinada entre los servicios sociales y sanitarios, para lo cual se preveía un convenio marco entre los Ministerios de Sanidad y Asuntos Sociales en el que se concretaría la colaboración de ambos departamentos en programas sociosanitarios, iniciativa que tuvo cierto reflejo en la Ley 16/2003, de 28 de mayo, de Cohesión y Calidad del Sistema Nacional de Salud -art. 14-. 
En todo caso, desde 1982 a 1992 la práctica totalidad de las Comunidades Autónomas promulgó una Ley propia en materia de servicios sociales o de acción social (en Andalucía, la Ley 2/1988, de 4 de abril, de servicios sociales). Con pequeñas diferencias y salvo alguna excepción, cada una de estas Leyes pretende articular un sistema propio que se declara "público" de servicios sociales, integrado por los servicios sociales tanto de titularidad pública -autonómica y local- como de iniciativa social, y estructurado en dos niveles: un nivel primario, constituido por los servicios sociales básicos o comunitarios (servicios de información y orientación, ayuda a domicilio, programas de prevención...), cuya gestión se confía fundamentalmente a las Administraciones Locales (Ayuntamientos y, en su caso, Diputaciones Provinciales); y un nivel secundario, integrado por los llamados servicios sociales especializados, esto es dirigidos a colectivos con necesidades sociales específicas, entre los cuales se mencionan siempre a los ancianos o personas mayores, y cuya gestión sería responsabilidad de la Administración autonómica y, en su caso, de las Diputaciones Provinciales. En todo caso, debe destacarse la vocación común por implantar un sistema de responsabilidad pública, dentro del cual se encuadraría la atención a las personas mayores ${ }^{12}$.

Asimismo, algunas Comunidades Autónomas se dotaron posteriormente, ya a partir de la década de los 90 , de específicas leyes de atención y protección a las personas mayores ${ }^{13}$. Ahora bien, en general, estas leyes específicas no alteran la configuración general antes referida de los servicios sociales para personas mayores. Así, la Ley de Andalucía 6/1999, de 7 de julio, de atención y protección a las personas mayores, sigue estructurando los servicios sociales

\footnotetext{
${ }^{12}$ En cuanto a su contenido, la doctrina ha señalado que se trata de "leyes manifiesto", retóricas, semánticas: sus preceptos son mayoritariamente normas de acción, programáticas, que tienen por destinatario principal a la propia Administración autonómica, con una ausencia casi total de normas relacionales, únicas aptas para generar derechos subjetivos directamente accionables, los cuales son diferidos al nivel reglamentario. Vid., en general, A. GARCÉS SANAGUSTÍN, Las prestaciones económicas en el ámbito de la protección asistencial, Cedecs, Barcelona, 1996; J.M ${ }^{\mathrm{a}}$ ALONSO SECO- B. GONZALO GONZÁLEZ, La asistencia social y los servicios sociales en España, BOE, 2aㅡ ed., Madrid, 2000.

${ }^{13}$ Fue pionera la Ley del Principado de Asturias 7/1991, de 5 de abril, de asistencia y protección al anciano, a la que siguieron las siguientes: Ley de Extremadura 2/1994, de 28 de abril, de asistencia social geriátrica; Ley de Canarias 3/1996, de 11 de julio, de participación de las personas mayores y solidaridad entre generaciones; Ley de Andalucía 6/1999, de 7 de julio, de atención y protección a las personas mayores; Ley de Castilla y León 5/2003, de 3 de abril, de atención y promoción a las personas mayores. Vid. M. MORENO REBATO, "La protección de la tercera edad”, Documentación Administrativa, núm. 271, 2005, págs. 273 y ss.
} 
para personas mayores en servicios sociales comunitarios, cuyo objetivo básico es promover la integración y participación de las personas mayores en la sociedad, favoreciendo el mantenimiento en su medio habitual y evitando su marginación -art. 12-, y servicios sociales especializados, en cuanto instrumentos dirigidos específicamente para la atención a las personas mayores -art. 14-, y dentro de los cuales se incluyen a los centros residenciales ${ }^{14}$.

En todo caso, existe hoy en día un consenso absoluto sobre la prioridad del modelo comunitario. Las políticas sociales de atención a las personas mayores de los países desarrollados tienen por objetivo preferente "envejecer en casa”. Las posiciones que postulaban el aislamiento de las personas atendidas en aras de una correcta "atención medicalizada" se han visto definitivamente superadas por aquellas que preconizan la integración social y la normalización de los servicios. De este modo, el modelo comunitario defiende la atención de los problemas de las personas allí donde se producen, sin que tengan que sufrir el desarraigo que genera el abandono del entorno habitual de convivencia. En este sentido, los servicios de atención giran en trono al domicilio, y se incluye en su caso a la familia como destinataria de los mismos ${ }^{15}$.

Por tanto, el objetivo prioritario debe ser mantener al mayor en el entorno sociofamiliar en el que ha desarrollado su vida, de tal modo que el ingreso en una residencia se configura como una medida claramente subsidiaria ${ }^{16}$.

14 Por su parte, la Ley de Castilla y León 5/2003 - art. 29- opta por diferenciar tres tipos de actuación: la Tipo I tendría por finalidad la información, orientación y sensibilización; la Tipo II tendría por finalidad facilitar la permanencia en el entorno familiar, y la Tipo III ofrecer una atención integral y continuada a aquellas personas que no pueden permanecer en su domicilio habitual.

15 Defensor del Pueblo. La atención sociosanitaria en España: perspectiva gerontológica y otros aspectos conexos, p. 82. Ya el Informe del Senado sobre La situación de las residencias de la tercera edad en España y alternativas a las mismas desde la perspectiva actual, 1989, p. 12677, señalaba que la idea básica que debe presidir el orden de los servicios es la de evitar alterar, en lo posible, el marco habitual de vida de las personas, y los servicios han de crearse allí donde se encuentre la necesidad. Así, el Senado recomendó a las instituciones públicas a tomar como punto de partida para el establecimiento de sus actuaciones en cuanto a servicios de la tercera edad, el respeto a la independencia y responsabilidad del anciano orientando los servicios para preservar su autonomía y su inserción familiar y social, de tal modo que la asistencia a los ancianos dentro del hogar debe tener preferencia institucional como servicio básico.

${ }^{16}$ En consecuencia, las situaciones residenciales deben limitarse a quienes estén condicionados por situaciones de invalidez o alto riesgo de contraerla. Senado, Ponencia de la Comisión de Sanidad y Asuntos Sociales para el "estudio de la problemática del envejecimiento de la población española, 1999. Asimismo, las referencias normativas a esta prioridad son múltiples: Ley de Canarias 3/1996; Ley de Andalucía 6/1999 -art. 1.d)-; Ley de Castilla y León 5/2003 -art. 12.2-. 
Evidentemente este criterio comporta articular una serie de medidas orientadas a favorecer esa permanencia, en la medida de lo posible, en el contexto sociofamiliar, y en las que no podemos detenernos dado el objeto de este trabajo ${ }^{17}$. Con todo, debe señalarse que esta prioridad de los dispositivos comunitarios puede llevar a adoptar medidas más enérgicas que las planteadas hasta el momento en nuestro país, y que afecten directamente a la oferta de residencias ${ }^{18}$.

\subsection{El sector de centros residenciales para personas mayores}

\subsubsection{Caracterización y tipología de los centros residenciales para personas mayores}

La noción misma de centro residencial para personas mayores ha evolucionado en los últimos años, pues hasta hace bien poco se caracterizaba exclusivamente por su función de alojamiento permanente ${ }^{19}$, mientras que en la actualidad la noción gira en torno a la atención integral al usuario. Así, la Ley de Andalucía 6/1999 -art. 15- configura los centros residenciales como centros de alojamiento y de convivencia que tienen una función sustitutoria del hogar familiar, ya sea de forma temporal o permanente, donde se presta a la persona mayor una atención integrat ${ }^{20}$. Es evidente que esta nueva configuración comporta importantes exigencias en cuanto a los servicios que deben prestar estos centros en relación con lo que ha venido siendo el funcionamiento ordinario de los mismos ${ }^{21}$.

${ }^{17}$ Fomento de la autonomía personal de los mayores, mejora de las condiciones de habitabilidad y acceso de la vivienda, apoyo a las familias que conviven con sus mayores, con especial atención a la figura del cuidador efectivo de los mismos, servicios de ayuda a domicilio y teleasistencia, alojamientos alternativos temporales, reconversión de los clubes y hogares para la tercera edad en centros de día polivalentes...

${ }^{18}$ En Dinamarca, por ejemplo, se prohibió en 1988 la construcción de nuevas residencias, a través de la Ley sobre Viviendas para Personas Mayores y Discapacitados, que entró en vigor el 1/7/1987. En su lugar se llevó a cabo una política de vivienda que reforzaba la construcción de viviendas adaptadas a este colectivo, persiguiendo así el objetivo de mantener a las personas mayores en su entorno social y de reforzar una vida independiente.

19 Así, todavía la Ley de Asturias 7/1991, de 5 de abril, de asistencia y protección al anciano, considera establecimientos residenciales para ancianos aquellos destinados a servir de residencia permanente o habitual a esta población -art. 2-.

20 Por su parte, la Ley de Castilla y León 5/2003 -art. 31.1- añade "atención integral, continuada y 'profesional durante las veinticuatro horas del día”.

21 Así, el Diputado del Común de Canarias, "Diagnóstico de la situación de los centros para personas mayores en Canarias", 2001, señaló que, en consonancia con la escasez de personal, las 
Asimismo, tradicionalmente se ha distinguido entre residencias, o más exactamente, plazas residenciales para personas "asistidos" y "válidos", en función de que atiendan a personas con una discapacidad tan grave que precisen de la ayuda de otra persona para la realización de actividades de la vida diaria, de aquellos otros que atiendan a personas con cierta autonomía personal ${ }^{22}$. También es frecuente hablar de residencias "mixtas", en las que se combina un número de plazas para personas mayores con autonomía y otro para "asistidas". De hecho, las residencias para "válidos", a medida que una parte de los residentes van perdiendo autonomía, acaban funcionando como residencias "mixtas" 23 .

$\mathrm{Al}$ margen de lo censurable de la terminología ${ }^{24}$, debe destacarse que durante los años 80 y primeros de los 90 el objetivo prioritario se centró en la construcción de residencias de tamaño medio o grande, ubicadas en zonas periféricas de los centros urbanos, dirigidas fundamentalmente a personas mayores con un aceptable nivel de autonomía funcional, no aptas para personas afectadas de dependencia grave, pero con importantes problemas socioeconómicos ${ }^{25}$. En la actualidad es evidente que se trata de una política errónea, pues en los servicios institucionales, tanto por razones de principio referidas a la prioridad del modelo comunitario antes señalada, como por razones prácticas debido a la escasez y coste elevado de estos recursos, se impone la reconversión de las plazas para personas "válidas" en plazas de asistidos, pues al menos en el ámbito público la atención residencial debe restringirse a aquellas personas en situación de dependencia ${ }^{26}$. En este sentido, puede observarse

actividades en las residencias suelen ser limitadas, y se nota una gran ausencia de actividades de rehabilitación, de animación sicogeriátrica, de terapia ocupacional, etc., mientras que la actividad de ocio más practicada en las residencias consiste en ver la televisión o salir de excursión.

${ }^{22}$ Ley de Canarias 3/1996 -arts. 25 y 26-.

${ }^{23}$ Vid. Valedor do Pobo, en su Informe extraordinario "Situación de los ancianos en Galicia", junio 1994, p. 416; Diputado del Común, "Diagnóstico de la situación de los centros para personas mayores en Canarias", 2001, p. 62.

${ }^{24}$ Algunas normas introducen diferencias nominativas. Así, por ejemplo, la Ley de Extremadura 2/1994 habla de "centros residenciales para ancianos con autonomía" -art. 16-.

${ }^{25}$ Vid. D. CASADO, "Notas sobre el futuro de los servicios sociales: nuevas necesidades, actividades y garantías”, Documentación Administrativa, núm. 217-2722, 2005, p. 200.

26 Así lo sugirió ya el Defensor del Pueblo del Estado en su informe especial de 1990; o el Defensor del Pueblo Andaluz en su Informe correspondiente al año 1992; y también el Informe del 
que desde la Administración del Estado se está subvencionado a entidades sin ánimo de lucro de ámbito estatal programas de adecuación de plazas para personas dependientes en centros gerontológicos de estancia permanente ${ }^{27}$.

\subsubsection{Estructura del sector de los centros residenciales para mayores}

Aun cuando las Leyes autonómicas de servicios sociales pretendieron constituir un sistema de responsabilidad pública, en el sentido de que la Administración, autonómica y local, acapararan el protagonismo en la prestación de los servicios sociales, y, asimismo, se intentó desplazar a la iniciativa social "sin ánimo de lucro" a un papel estrictamente secundario y subordinado de mero "colaborador" de la Administración, omitiendo la menor referencia a la iniciativa social "con ánimo de lucro", la realidad ha ido por otros derroteros.

Como en cualquier otro servicio asistencial, la oferta de centros residenciales para personas mayores es diversa (lo que no quiera decir suficiente), pues existen tanto centros de titularidad pública -autonómicos y de Diputaciones provinciales, principalmente-, como de titularidad privada, y, dentro de éstos, de titularidad de entidades religiosas, de entidades sin ánimo de lucro -como Cruz Roja Española- y, en fin, de entidades lucrativas. Más aún, la tendencia es la del progresivo dominio del sector privado (la relación es 1/3 sector público, 2/3 sector privado), si bien debe señalarse que buena parte de estos centros de titularidad privada conciertan todas o parte de sus plazas con la Administración ${ }^{28}$.

Senado, BOCG, Senado, Serie I, 22 de junio de 1989, núm. 326, La situación de las residencias de la tercera edad en España y alternativas a las mismas desde la perspectiva actual, 1989, p. 12682. Igualmente, la Ponencia de la Comisión de Sanidad y Asuntos Sociales del Senado, para el "Estudio de la problemática del envejecimiento de la población española”, BOCG, Senado, Serie I, núm. 805, de 17 de diciembre de 1999; o el Valedor do Pobo, en su Informe extraordinario "Situación de los ancianos en Galicia”, junio 1994, p. 486. También se prevé este criterio en algunas normas: Ley de Canarias 3/1996 -art. 11-; Ley de Castilla-La Mancha 5/1995 de Solidaridad -art. 25-. De forma tajante, la Defensora del Pueblo de Navarra, Informe especial al Parlamento de Navarra "La atención a la dependencia de las personas mayores en Navarra", marzo de 2005, p. 203, señala: "Las plazas de válidos no debían de existir y, si las hubiera, no deberían recibir aportación de dinero público".

27 Vid. Resolución de 21 de diciembre de 2006, de la Secretaría de Estado de Servicios Sociales, Familias y Discapacidad, por la que dispone la publicación de las subvenciones concedidas al amparo de lo dispuesto en la Orden TAS/892/2006, de 23 de marzo. BOE núm. 22, de 25 de enero de 2007 .

28 En 1995 se estimaba que los centros residenciales privados para la tercera edad existentes en España constituyen el 77,2 \% del total, de modo que sólo el 22,8\% restante es de titularidad pública -Guía Directorio de centros para personas mayores, INSERSO de 1995-. Once años después, se- 
Por esta razón, con independencia de su titularidad pública o privada, el régimen jurídico de los centros pivota sobre la distinción entre centros integrados en el sistema o red pública autonómica de servicios sociales (centros públicos y privados concertados) y centros privados ajenos a dicha red pública (centros privados no concertados). No obstante, la realidad es más compleja, pues es muy frecuente que un mismo centro privado tenga una parte de sus plazas concertadas y el resto de oferta libre. Por ello, a efectos de determinar el grado de cobertura del sistema público, es preferible hablar de "plazas" con cobertura pública más que de centros. Con todo existe, o debería existir, un régimen común a todos los centros públicos y privados, al que nos referimos a continuación.

\subsection{Régimen común a todos los centros residenciales para personas mayores}

\subsubsection{Demora en la reglamentación y tolerancia en la adaptación a la misma.}

Parece incuestionable que todos los centros, con independencia de su adhesión al sistema público, deben cumplir unos requisitos materiales y funcionales mínimos ${ }^{29}$, con independencia de la adhesión de un centro residencial al sistema público. Para la determinación de las condiciones y requisitos que han de reunir los centros, como es lógico, las Leyes autonómicas se remiten al desarrollo reglamentario ${ }^{30}$. En Andalucía, aun cuando la Ley 2/1988, de 4 de abril, de Servicios Sociales de Andalucía dispuso en su artículo 13 que todos

gún el documento "Las personas mayores en España 2006”, el número total de plazas residenciales a enero 2006 era de 298.870 , y un $56 \%$ de ellas privadas. Están distribuidas en 4.888 centros de los que 3.886 pertenecen al sector privado. El $52 \%$ de las plazas son para personas dependientes. Las diferencias entre comunidades son, además, muy acusadas. Castilla-La Mancha, Extremadura y País Vasco son las Comunidades con más plazas públicas o concertadas en residencias. Por el contrario, Castilla y León y Navarra son las que más apuestan por las plazas privadas (dos de cada tres plazas en estas comunidades son de gestión privada).

${ }^{29}$ La necesidad de que las Comunidades Autónomas aprueben esta normativa sobre residencias privadas fue ya una recomendación formal del Informe del Senado, La situación de las residencias de la tercera edad en España y alternativas a las mismas desde la perspectiva actual, 1989, p. 12682. Pero lo cierto es que si se tiene presente que nadie cuestiona la competencia de la autoridades para reglamentar las condiciones que deben cumplir los establecimientos de alojamiento turístico, con mayor razón en el caso de las residencias para personas mayores, al tratarse de un colectivo con mayor grado de indefensión.

${ }^{30}$ Ley de Asturias 7/1991 -art. 4-; Ley de Extremadura 2/1994 -art. 17-; Ley de Canarias 3/1996 -art. 19-; Ley de Castilla y León 5/2003 -art. 31-. 
los centros dedicados a la prestación de servicios sociales deberán ajustarse a las condiciones que se establezcan reglamentariamente, lo cierto es que hasta 1996 no se aprobó la normativa de mínimos materiales, funcionales y de recursos humanos para los Centros de atención especializada para Personas Mayores, y que si bien fue suplida mediante acuerdos particulares en relación con los centros concertados, dejó sin punto de referencia normativo al resto de los centros ${ }^{31}$.

Este inexcusable silencio fue causa de una enorme inseguridad jurídica, que sufrieron, por una parte, las Entidades promotoras de residencias para mayores, al ignorar el nivel de prestaciones y de calidad exigibles por las autoridades administrativas (bajo el riesgo de que una futura ordenación de los factores técnicos y funcionales les obligara a realizar las oportunas adaptaciones, con el consiguiente coste económico), y, de otra parte, los propios usuarios de tales centros, que tampoco han podido reclamar, al amparo de una norma, un mínimo grado asistencial a ofrecer por su residencia. La indefensión que esta situación ha generado es patente y no tiene mayor explicación que la inexcusable pasividad de la Administración.

Debido justamente a la intervención del Defensor del Pueblo andaluz, fue aprobado el Decreto 87/1996, de 20 de febrero, por el que se regula la autorización, registro, acreditación e inspección de Entidades y Centros de Servicios Sociales de Andalucía, que contempla a los centros residenciales para personas mayores ${ }^{32}$. No obstante, debe señalarse que se han contemplado todo tipo de prórrogas para los centros ya en funcionamiento a la entrada en vigor del Decreto 87/1996, que suscitan dudas sobre el grado de adaptación real de mismos a las exigencias contenidas en la normativa ${ }^{33}$.

\footnotetext{
${ }^{31}$ Esta inactividad normativa de la Administración fue denunciada por el Defensor del Pueblo andaluz, "Investigación sobre las Residencias de Ancianos Ilegales", Informe al Parlamento de Andalucía 1995, p. 922: "Ahora bien, si las condiciones mínimas de calidad exigibles a un centro concertado únicamente se han podido establecer mediante acuerdos particulares, los requisitos materiales, funcionales y de recursos humanos que ha de cumplir un centro para poder obtener su autorización ni siquiera han quedado determinados, por lo que no existe en la actualidad ningún punto de referencia normativo al respecto".
}

32 El Decreto 87/1996 fue modificado por Decreto 102/2000, de 15 de marzo, y desarrollado por la Orden de 28 de julio de 2000, por la que se regulan los requisitos materiales y funcionales de los Servicios y Centros de Servicios Sociales de Andalucía y se aprueba el modelo de solicitud de las autorizaciones administrativas.

33 El Decreto 87/1996, de 20 de febrero, en su Disposición Transitoria Primera, establece que los centros en funcionamiento que "no reúnan los referidos requisitos (para la autorización) que- 
2.3.2. Requisitos materiales y funcionales de los centros residenciales para personas mayores

De entrada, para facilitar la aplicación de las normas sobre requisitos materiales y funcionales a todos los establecimientos, incluidos los privados que no conciertan sus servicios con la Administración, es fundamental que por Ley quede perfectamente delimitada la actividad sujeta a esta normativa, con independencia de su denominación formal, algo que no sucede siempre, abriéndose vías de escape a la aplicación de las normas del sector -alegándose, por ejemplo, que el centro es cuestión es un mero hostal- ${ }^{34}$.

Asimismo, además de requisitos materiales -acceso y recorridos interiores, instalaciones, dependencias, aspectos higiénico-sanitarios, medidas anti-incendios...-, el centro debe cumplir unos requisitos funcionales, que per-

dan obligados a adecuarse a las condiciones materiales y funcionales que se establezcan en el plazo máximo de 3 años a partir de la entrada en vigor de las normas que fijen dichas condiciones". No obstante, cuando se cumplió dicho plazo, se aprobó el Decreto 102/2000, de 15 de marzo, el cual mediante la Disposición Transitoria Primera, dispuso que los centros en funcionamiento con anterioridad a la entrada en vigor del Decreto 87/1996, y que tuvieran pendientes de resolución sus solicitudes de autorización o inscripción quedaron habilitados para continuar su funcionamiento, determinación de dudosa licitud de cara al principio de igualdad en aplicación de la ley. $\mathrm{Y}$, de modo similar, los plazos para adaptarse a los requisitos de la acreditación por parte de los centros con plazas concertadas se prorrogaron en varias ocasiones: el plazo máximo de dos años previsto en la Orden de 30 de agosto de 1996, se amplió por las Órdenes de 9 de marzo de 1998 (hasta finales de 1999) y 22 de marzo de 1999 (hasta finales de 2000). La cuestión puede volverse aún más vidriosa si se tiene presente que las exigencias establecidas en el precedente Decreto 94/1989 habían sido también objeto de sucesivas prórrogas: Decreto 161/1991, de 30 de Julio (BOJA nº 68, de 3 de Agosto) y Orden de 1 de Abril de 1992 (BOJA no 31, de 11 de Abril), de la Consejería de Asuntos Sociales. Así, en su informe de 1995 el Defensor del Pueblo de Andalucía constató que existen Residencias que gozan de la correspondiente autorización administrativa, sin que por el contrario se encuentren acomodadas al Decreto 94/1989, de 3 de Mayo, y que se encuentran en una situación de "transitoriedad indefinida", pues desarrollan su actividad al amparo de la permisividad que al respecto muestra la Administración. Con todo, puede señalarse que situaciones similares de prórroga de adaptación se han dado en otras Comunidades Autónomas, como es el caso en Castilla y León del Decreto 295/1994, de 22 de diciembre, por el cual se ampliaron los plazos de adaptación inicialmente previstos en el Decreto 109/1993, en algunos casos hasta 1997.

${ }^{34}$ En este sentido, la Ley de Extremadura 2/1994 entiende "por establecimiento residencial o centro dedicado a la atención a las personas mayores, el conjunto de inmuebles y servicios destinados al alojamiento, sea transitorio o permanente, a la atención alimenticia y a todas aquellas atenciones asistenciales dirigidas a diez o más personas de las comprendidas" en el ámbito de la Ley -art. 14.1-. 
miten deslindar este equipamiento de un establecimiento turístico. Estas condiciones funcionales -cuya supervisión es más ardua que las exigencias materiales, para las que basta una visita de inspección- se traducen fundamentalmente en el programa o proyecto de intervención, que contenga una serie de prestaciones: sanitarias (atención médica y enfermería, fisioterapia, terapia ocupacional- y psicosociales -atención psicológica, intervención con familias, animación socio-cultural, entrenamiento en habilidades básicas-.

\subsubsection{El reglamento de régimen interior de los centros}

Las Administraciones han venido aprobando disposiciones en las que se ordena la elaboración y aprobación en las residencias públicas de reglamentos de régimen interior ${ }^{35}$. Pero en algunas Comunidades Autónomas se ha dado el paso de extender a los centros privados la obligatoriedad de disponer de un reglamento de régimen interior regulador de su organización y funcionamiento, normas de convivencia, órganos de participación y derechos y deberes de los residentes del centro. Asimismo, el reglamento de régimen interior y sus eventuales modificaciones deberán ser "visados" 36 o "aprobados" por la Administración ${ }^{37}$. Lo cierto es que la existencia y publicidad de un Reglamento de régimen interno constituye un instrumento de seguridad jurídica, y a la postre, posibilita el control jurisdiccional sobre aspectos relacionados con los derechos y deberes de los usuarios -régimen de visitas, salidas al exterior...-, que de otro modo quedarían confiados a la discrecionalidad de la dirección del centro. Asimismo, sólo a través de estas normas se garantiza la par-

${ }^{35}$ Por Orden de 16 de mayo de 1985, modificada ligeramente por Orden de 4 de junio de 1993, se aprobó el Estatuto Básico por el que se rigen los centros y residencias de ancianos dependientes del antiguo Instituto Nacional de Servicios Sociales. En Andalucía, por Orden de 21 de junio de 2006, se aprueba el Reglamento de Régimen Interior de los Centros Residenciales de Personas Mayores de titularidad de la Junta de Andalucía (BOJA núm. 135, de 14 de julio de 2006), y que sustituye a reglamentaciones anteriores.

${ }^{36}$ Ley de Asturias 7/1991 -art. 6.1-. La regulación más completa y correcta es la de la Ley de Asturias 7/1991: "La Administración de servicios sociales podrá formular reparos cuando advierta que sus preceptos no se ajustan a la legalidad vigente". Asimismo, la norma contempla para este procedimiento un supuesto de silencio estimatorio. Por lo demás, una vez visado el reglamento, ese debe exponerse en el tablón de anuncios del centro y un ejemplar del mismo se entregará al usuario en el momento de su ingreso en el establecimiento -art. 6.4-. De modo idéntico, la Ley de Extremadura 2/1994 -art. 19.3-.

${ }^{37}$ Ley de Extremadura 2/1994 -art. 19.1-; Ley de Canarias 3/1996 -art. 20-; Ley de Andalucía 6/1999 -art. 8-. 
ticipación democrática de los usuarios en el funcionamiento de los centros ${ }^{38}$. Relacionado con esto sería la obligación de todo establecimiento de disponer de un sistema de quejas y sugerencias ${ }^{39}$.

Por último, debería exigirse a todos los centros la designación de un Director o Directora con la titulación adecuada ${ }^{40}$.

\subsubsection{Los derechos de los usuarios de los centros}

Por encima de lo dispuesto en los reglamentos de régimen interior, las leyes autonómicas sobre servicios sociales, tanto generales -las más recientescomo específicas sobre personas mayores ${ }^{41}$, están incluyendo catálogos de derechos de los usuarios de centros residenciales de servicios sociales, sobre los que planea cada vez con mayor fuerza el alcance de los derechos fundamentales, empezando por el derecho a la libertad personal que impone la voluntariedad del ingreso y de la permanencia en el centro y a mantener relaciones interpersonales, y siguiendo con otros derechos también fundamentales, como los derechos a la integridad física y moral, a la igualdad de trato, a la intimidad personal o, en fin, a la dignidad de la persona, derechos todos ellos que

\footnotetext{
${ }^{38}$ El Defensor de Pueblo ha insistido en diversas ocasiones en la necesidad de que los centros de servicios sociales cuenten con un reglamento de régimen interior propio. Vid. Informe a las Cortes Generales 1994, pp. 851 y 926. Como certeramente ha señalado la Defensora del Pueblo de Navarra, Informe especial al Parlamento de Navarra "La atención a la dependencia de las personas mayores en Navarra", marzo de 2005, es patente que la carencia de reglamento de régimen interior, es decir, de unas reglas de juego puede tener graves consecuencias para los residentes: "Cuando no hay un marco normativo claro, las pautas relacionales entre usuarios y profesionales tienden, de forma natural, a concepciones ligadas al pasado institucional en el que los residentes no eran sujetos de derecho sino puramente beneficiarios asilados que debían aceptar lo que la Institución decidiera sobre el servicio, de modo que el deseable equilibrio de poderes entre residentes y los profesionales, basculaba siempre del lado de éstos últimos”.
}

${ }^{39}$ Ley de Extremadura 2/1994 -art. 20-.

${ }^{40}$ Así el Decreto del Gobierno de Canarias 63/2000, de 25 de abril, por el que se regula la ordenación, autorización, registro, inspección y régimen de infracciones y sanciones de centros para personas mayores y sus normas de régimen interno, establece que todos los centros residenciales contarán con un/a Director/a que deberá tener titulación universitaria o bien experiencia acreditada durante tres años, ejerciendo funciones de dirección.

${ }^{41}$ Ley de Asturias 7/1991 -art. 15.2-; Ley de Extremadura 2/1994 -art. 28-; Ley de Andalucía 6/1999 -art. 20-. 
presentan, en mayor o menor medida, problemas de afección en la praxis diaria $^{42}$. Asimismo, un aspecto importante es la salvaguarda de un mínimo de libertad en su vida íntima para la realización afectivo-sexual de los internos $^{43}$. Otros derechos son de contenido prestacional, como el derecho a recibir una atención individualizada ${ }^{44}$. En todo caso, las normas autonómi-

42 La libertad deambulatoria está a veces seriamente comprometida, pues no es infrecuente que, a instancia de los familiares, se les prohíba a los ancianos salir al exterior de la Residencia y recibir visitas, de forma que todo su mundo queda reducido a las dependencias que componen el Centro, y sin que esta restricción esté avalada por la autoridad judicial. Y esta limitación se intenta justificar por la minusvalía que sufran los usuarios cuando tal situación lo único que explica es que no se les permitiese salir solos. Por ello, no basta con reconocer el derecho, tal como declaran las Leyes anteriores, sino que es preciso también obligar al centro o servicio a que pongan los medios para hacer efectivo ese derecho de acceso al exterior, p. ej. en compañía de los cuidadores. Asimismo, en muchos centros existen salas de aislamiento y medios mecánicos de contención, sin que la utilización de uno u otro medio, además de no estar sometida a una actuación protocolizada por escrito, se comunique a la autoridad judicial. De modo similar, la intimidad de las personas determina que cada individuo tenga derecho a preservar del conocimiento e intervención ajenos datos y acciones que sólo a él incumbe, teniendo los restantes sujetos el deber de abstenerse de toda irrupción dentro de ese ámbito. Pues bien, muchos internos en Residencias carecen de esa esfera mínima de privacidad, de una parte, por la masificación existente en las mismas, y, de otra, porque el control que se ejerce por los representantes de tales Centros es tan intenso que nada escapa a su conocimiento, lo que limita sobremanera la capacidad de iniciativa y de relación de los residentes. Defensor del Pueblo Andaluz, Informe al Parlamento de Andalucía 1995, pp. 64 y 65. Vid también H. SOTELO IGLESIAS, "Algunas consideraciones acerca de los derechos de las personas ancianas en Residencias", Ararteko, "El año internacional de las personas mayores", Los derechos no caducan con la edad: el año internacional de las personas mayores. San Sebastián, 1999, pp. 83 y ss.

43 El Valedor do Pobo, en su Informe extraordinario "Situación de los ancianos en Galicia", junio 1994, p. 262, señalaba que estos derechos son conculcados en las residencias de mayores: "Unas veces son los prejuicios de la sociedad los que se han contagiado a diseñadores, reglamentos y dirección de las residencias. Otras son los propios hijos o familiares, que imparten órdenes a la dirección”. Puede aquí recordarse que el Plan de Acción para las Personas Mayores 2003-2007 contempló, entre sus objetivos, la promoción de Comités asistenciales de Bioética en los Centros residenciales gerontológicos de mayor entidad.

44 En este sentido, algunas normas establecen que los centros residenciales deben elaborar programaciones individuales de desarrollo psíquico-social ajustadas a la edad y características de cada usuario, con objeto de impulsar su autonomía personal y su integración social. Resolución del Instituto Andaluz de Servicios Sociales de 24 de octubre de 1996, por la que se aprueba el modelo tipo de pliego de condiciones reguladoras de la concertación de plazas en centros residenciales para personas mayores. 
cas sobre derechos de los usuarios deberían descender a un mayor detalle del que es común ${ }^{45}$.

\subsubsection{Régimen de autorización de los centros}

Siguiendo aparentemente el criterio de la legislación sanitaria ${ }^{46}$, en la legislación autonómica sobre servicios sociales es común diferenciar dos niveles de exigencia de requisitos de los Centros asistenciales: autorización y acreditación ${ }^{47}$. En Andalucía, el citado Decreto 87/1996, de 20 de febrero, adoptó ese sistema dual ${ }^{48}$.

En lo que se refiere a la autorización, ésta se configura al modo clásico como técnica de intervención administrativa, si bien en este ámbito se trata de un intervencionismo muy intenso ${ }^{49}$. En todo caso, la falta de autorización su-

45 Así, por ejemplo, en Canarias, el Decreto 63/2000 establece que el régimen de visitas será abierto, e incluirá la posibilidad de acceder, con el debido orden, a las habitaciones de los usuarios. "El régimen de entradas y salidas será libre, fomentándose la integración de los usuarios en el entorno normal de la comunidad". Otra cuestión es la generalización de habitaciones dobles. Como ha señalado, el Diputado del Común de Canarias, "Diagnóstico de la situación de los centros para personas mayores en Canarias”, 2001, el respeto a la intimidad exige, y lo hará con más intensidad en el futuro, la generalización de habitaciones individuales. Vid., sobre esta temática, Centro de documentación y estudios, SIIS, Los derechos de los residentes y las especificidades del medio residencial ¿̨cómo compaginarlos?, San Sebastián, 2001.

${ }^{46}$ La Ley General de Sanidad -art. 90.5- dispuso que los centros sanitarios susceptibles de ser concertados por las Administraciones públicas sanitarias deberán ser previamente homologados por aquéllas, de acuerdo con un protocolo definido por la Administración competente.

47 Ley Foral 20/1985, de 25 de octubre, de Conciertos en materia de Servicios Sociales; Decreto del Consejo de Gobierno de la Comunidad Valenciana 40/1990; Decreto del Consejo de Gobierno de Castilla-La Mancha 60/1991; Decreto del Consejo de Gobierno de Castilla y León 109/1993, de 20 de mayo. En el ámbito específico de la tercera edad, Ley de Asturias 7/1991 -art. 9-; Ley de Extremadura 2/1994 -art. 22-.

48 Asimismo, el régimen del Decreto 87/1996 fue precedido por el establecido en el por el Decreto 94/1989, de 3 de Mayo (BOJA nº 39, de 19 de Mayo), por el que se fijaban las normas de registro y acreditación de Entidades y Centros. Esta norma contemplaba un Consejo de Acreditación de dudoso funcionamiento en la realidad.

49 Están sujetos a autorización administrativa los actos de creación o construcción, puesta en funcionamiento y modificación sustancial, bien estructural o funcional de centros y servicios y de traslado. Los actos de cambio de titularidad y los de cese del servicio o cierre del centro requeri- 
pone, según el artículo 17 del Decreto 87/1996, la no inscripción en el Registro de Entidades o su exclusión, así como la exclusión de ayudas, subvenciones o conciertos financiados con fondos de la Comunidad Autónoma, la imposibilidad de acreditación o, incluso, la imposición de sanciones administrativas. Así, legalmente, el funcionamiento de un centro desprovisto de autorización determina el carácter clandestino del mismo, y es un hecho constitutivo de infracción ${ }^{50}$.

Pero, sobre todo, importa destacar, como señalara el Defensor del Pueblo andaluz, que dado que los usuarios de estos servicios (ya sean públicos o privados) constituyen un colectivo con un cierto grado de desvalimiento y autoprotección para la defensa de sus derechos y denunciar casos de abuso y de lesión sobre su persona o sus bienes, la autorización administrativa, no es un mera formalidad administrativa, sino que cumple la función de garantizar a los usuarios que accedan a un centro que van a disfrutar de unas prestaciones y unos servicios mínimos, establecidos reglamentariamente, como una base irreductible de bienestar que en cualquier caso tienen asegurado; en suma, un elemento de protección de estos colectivos ${ }^{51}$. Y, en este sentido, tanto las Leyes autonómicas específicas para personas mayores disponen que la apertura y el funcionamiento de los centros de alojamiento o estancia estarán sujetos a la autorización de la Administración autonómica, así como sometidos a la inspección y control de la misma ${ }^{52}$.

rán únicamente la comunicación previa a la Consejería competente con una antelación mínima de tres meses -art. 5 Decreto-. Asimismo, se establecen dos tipos de autorizaciones -art. 10-. Los actos de creación o construcción y modificación sustancial, bien estructural o funcional, de centros y servicios se someten al régimen de autorización previa, que tiene por objeto comprobar la adecuación del proyecto a las condiciones mínimas materiales. En cambio, los actos de puesta en funcionamiento de un servicio o centro están sometidos al régimen de autorización de funcionamiento, que comprueba el cumplimiento de los requisitos mínimos funcionales, y que se solicitará una vez obtenida la autorización previa y, en su caso, la licencia de obra -art. 12-, y que requiere, en todo caso, una visita previa de inspección.

${ }^{50}$ Tanto el Decreto 87/1996 -art. 33.4- como la posterior Ley de Andalucía 6/1999 -art. 53consideraron esta falta como infracción muy grave.

${ }^{51}$ Defensor del Pueblo andaluz, "Investigación sobre las Residencias de Ancianos Ilegales", Informe al Parlamento de Andalucía 1995, p. 929.

${ }^{52}$ Ley de Asturias 7/1991 -arts. 5, 8 y 22-; Ley de Extremadura 2/1994 -arts. 18, 21 y 30-; Ley de Canarias 3/1996 -art. 21-. 


\subsubsection{Gestión de la calidad}

En general, hasta fechas bien recientes, no se ha prestado la suficiente atención a la incorporación a este sector de las modernos instrumentos de gestión de la calidad, que introducen la autoevaluación y evaluación externa de los servicios. De este modo, el empleo de estas medidas tiene por finalidad obtener ventajas en el mercado de cara a los usuarios o recibir voto de confianza por parte de las entidades que aportan la financiación ${ }^{53}$. Sin embargo, es evidente que la promoción de la cultura de la calidad es un buen instrumento para garantizar la atención de los usuarios y el respeto a sus derechos, así como un complemento para la actuación de los servicios de inspección ${ }^{54}$.

A este respecto, en algunas Comunidades Autónomas se están dando pasos en orden a la implantación de los sistemas de calidad en los centros públicos y concertados, en el marco de las actuales exigencias de calidad de los servicios públicos ${ }^{55}$. Pero la Ley de Comunidad de Madrid 11/2002, de 18 de diciembre, de Ordenación de la Actividad de los Centros y Servicios de Acción Social y de Mejora de la Calidad en la Prestación de los Servicios Sociales, ha dado un paso más allá. En efecto, esta Ley obliga a los centros residenciales autorizados con cien o más usuarios, a tener certificado de evaluación de calidad emitido por Organismo acreditado a tal efecto, y que debe contemplar, en todo caso, los siguientes parámetros; satisfacción del usuario, profesionalización de la gestión, formación continua del personal y mejora continua de los procesos, así como las condiciones de accesibilidad y supresión de barreras arquitectónicas. Por su parte, los centros y servicios con menos de 100 usuarios

53 Como sería el certificado de calidad ISO 9001:2000.

${ }^{54}$ Así, el II Congreso Estatal de Personas Mayores, organizado por el Consejo Estatal de las Personas Mayores y celebrado en Madrid en junio de 2001, expresó la necesidad de establecer sistemas que garanticen la calidad y seguridad de los servicios.

${ }^{55}$ Es el caso en Cataluña del Decreto 284/1996, modificado por el Decreto 176/2000. También es el criterio de la Ley de La Rioja 3/2007, de 1 de marzo, de Calidad de los Servicios Sociales, la cual establece para los centros para personas dependientes propios una serie de programas y protocolos, inspirados en la mencionada normativa catalana -art. 19.2-. O, en Andalucía, de la Orden de 5 de julio de 2007 para los centros para discapacitados. No obstante, debe observarse que el Decreto catalán 284/1996, exige a todos los establecimientos de Servicios Sociales documentación directamente relacionada con la gestión de calidad; tales como programa anual de actividades, hojas de reclamaciones, contrato asistencial, expediente asistencial, libro registro de asistidos, protocolos de actuación y otros registros. 
deben realizar una "evaluación interna de la calidad de los servicios prestados de acuerdo con los requisitos que se definan reglamentariamente" -art. 12_ ${ }^{56}$.

\subsection{Régimen de los centros públicos}

\subsubsection{Aspectos generales}

Se incluyen aquí tanto los centros residenciales de titularidad pública gestionados directamente por una Administración pública, en sentido formal, ya sea territorial o instrumental, como aquellos otros gestionados por entidades con personalidad jurídico-privada dependientes de una Administración, como es el caso cada vez más frecuente de la utilización de fundaciones, y que también forman parte del sector público. También pueden incluirse en este apartado los casos, no muy frecuentes, de centros de titularidad pública pero cuya gestión ha sido objeto de concesión a un gestor privado ${ }^{57}$.

En los casos de centros de titularidad pública es evidente que las potestades de conformación de la Administración son más intensas, por ejemplo, a la hora de determinar aspectos tales como la ubicación, configuración y régimen de funcionamiento de los centros, pues en última instancia se trataría del ejercicio de una potestad autoorganizatoria.

Así, en cuanto a la configuración misma del centro, y con independencia de la existencia de sistemas alternativos al institucional, hoy en día es claro que el diseño de la residencia debe cumplir unas exigencias que minimicen los efectos de la institucionalización: así parece aconsejable huir de las macroresidencias, y sustituirlas por una red de centros de tamaño moderado -con un núm. de plazas próximo a $50-^{58}$, o incluso miniresidencias -de hasta 20 plazas-, en las cuales el trato es más personalizado y es más factible su alcance lo-

\footnotetext{
${ }^{56}$ Dichos requisitos podrán referirse a la elaboración de cartas de servicio, definición de protocolos específicos de actuación, certificación de procesos concretos, sistemas de información, definición de estándares e indicadores y planes de formación.

${ }^{57}$ En Andalucía, del Informe especial de la Cámara de Cuentas referido al año 2002, se infiere que en tal fecha existían cuatro residencias de titularidad pública en régimen de concesión situadas en Almería, Córdoba, Huelva y Málaga.

${ }^{58}$ El Plan Sectorial de Personas Mayores de Canarias (2001-2003) consideró óptima la residencia que se sitúa entre 40 y 60 plazas.
} 
cal o comarcal y su emplazamiento próximo al lugar de origen de los usuarios, facilitando el mantenimiento de sus lazos sociales ${ }^{59}$.

Asimismo, respecto a su emplazamiento, debe tenderse a minimizar el desarraigo y, por tanto, a posibilitar a que el anciano permanezca lo más próximo posible del marco en el que ha desarrollado sus actividades -barrio, pueblo, comarca...-, de tal modo que los recursos de alojamiento y estancia para personas mayores deben estar ubicados lo más próximos posible a las zonas de mayor actividad socio-comunitaria ${ }^{60}$.

Pero, al mismo tiempo, es evidente, que la responsabilidad de la Administración, en el más amplio sentido, es mayor, pues a la responsabilidad genérica de la Administración competente en materia de inspección de centros de servicios sociales en cada Comunidad Autónoma, puede sumarse una responsabilidad adicional de la Administración titular del centro o que concierte las plazas, en el caso de que sea distinta a la anterior (por ejemplo, una Administración local). Por ello, aun podría formularse otra distinción, en función de que la Administración gestora del centro sea la misma competente en materia de control e inspección de los centros (típicamente la Administración autonómica del territorio correspondiente), o bien otra Administración distinta (característicamente una Administración local). Esta distinción no es relevante a efectos de responsabilidad patrimonial, pero sí lo es en otro orden, pues los criterios organizativos más modernos propugnan una disociación entre las funciones de prestación de servicios y de regulador y supervisor de los mismos. Esto quiere decir que es conveniente que los centros de titularidad autonómica sean gestionados por una entidad autónoma (organismo autónomo, agencia...), diversa de la Administración responsable del control e inspección de los mismos.

\footnotetext{
${ }^{59}$ Senado, La situación de las residencias de la tercera edad en España y alternativas a las mismas desde la perspectiva actual, 1989, p. 12680.

${ }^{60}$ Ley de Andalucía 6/1999 -art. 14.2-. Por su parte, la Ley de Canarias 3/1996 añade que, además, el centro debe estar bien comunicado con los Servicios de Salud -art. 18-. Senado, La situación de las residencias de la tercera edad en España y alternativas a las mismas desde la perspectiva actual, 1989, p. 12677. Sin embargo, el Diputado del Común de Canarias, "Diagnóstico de la situación de los centros para personas mayores en Canarias", 2001, observó que un 35\% de las residencias visitadas tiene limitaciones de transporte, lo que dificulta la integración socio-comunitaria de los residentes. Igualmente, el Valedor do Pobo, en su Informe extraordinario "Situación de los ancianos en Galicia”, junio 1994, p. 485, señalaba que conviene que, en cuanto sea posible, los servicios sociales para ancianos - residencias, centros de día, clubes...- estén próximos a los usuarios.
} 


\subsubsection{Contribución de los usuarios a la financiación de los servicios}

A diferencia de lo que sucede en el sector sanitario donde rige la gratuidad de los servicios, en el campo de los servicios sociales se acepta desde hace tiempo la corresponsabilidad sociedad-Administración en la asunción del gasto, pues ni los poderes públicos pueden hacer frente en solitario a esta carga prestacional ni, por otra parte, parece razonable, desde el punto de vista de la racionalidad del gasto, que asuman el que generan personas que por su situación económica -y/o patrimonial- puedan soportarlo. De este modo, se establece que la prestación por parte de la Administración de los servicios residenciales no tiene carácter gratuito, sin perjuicio de que las personas que carezcan de recursos suficientes para abonar el importe de las mismas tengan derecho a la exención total o bonificación de un parte del coste efectivo de las plazas que ocupen ${ }^{61}$.

Ahora bien, dado el elevado coste de los servicios residenciales al mismo tiempo que el nivel de las rentas de las personas mayores es moderado o escaso, la cuestión de su financiación ha llevado a las autoridades a plantear diversas medidas. Una de las medidas consiste en computar tanto las rentas y bienes de la persona mayor como los de aquéllos obligados a prestarle alimentos $^{62}$. Sin embargo, se ha denunciado la situación en que se encuentran muchos ancianos con los que sus propios familiares rompen sus vínculos y rechazan asumir cualquier tipo de responsabilidad sobre ellos, descargando sus obligaciones personales y patrimoniales en la Administración. Así, se da la circunstancia de que los Servicios Sociales se ven obligados a ingresar en sus Centros a ancianos que se encuentran desasistidos por parte de unos familiares que disfrutan de una saneada economía, sin que ni siquiera puedan repetir frente a éstos los gastos que ello ocasiona, dado el carácter personalísimo del derecho de alimentos -art. 142 y ss. del Código civil-, que no es transmisible, y que únicamente puede ser ejercitado con el consentimiento del anciano ${ }^{63}$.

\footnotetext{
${ }^{61}$ Ley de Extremadura 2/1994 -art. 23.1-; Ley de Canarias 3/1996 -art. 23-, Ley de Andalucía 6/1999 -art. 22.1-.

${ }^{62}$ Ley de Andalucía 6/1999 -art. 22.1-. Lo cierto es que ya el Real Decreto 1273/1981, de 22 de mayo, estableció: "Los asistidos o, en su caso, los familiares obligados a la prestación de alimentos entre parientes conforme a lo dispuesto en el vigente ordenamiento jurídico, cooperarán a la financiación de los costos de estancia que se causen como consecuencia de la actividad asistencial en las prestaciones de asistencia, alimentación, rehabilitación, educación, formación y otras" -art. 1-.
}

63 Defensor del Pueblo Andaluz, Informe al Parlamento 1996, p. 802. 
Para afrontar a esta situación, se ha implantado el llamado contrato de "reconocimiento de deuda", pensado para personas que, sin tener recursos corrientes, sean titulares de un patrimonio susceptible de ser afectado a los gastos derivados de su internamiento ${ }^{64}$. Mediante este reconocimiento de deuda sobre bienes no líquidos se garantiza el pago de la contraprestación, e imposibilitan a los usuarios de los centros la transmisión inter vivos de sus bienes, y obligan incluso a sus herederos respecto de los bienes recibidos en herencia, todo ello "en razón de reciprocidad con la solidaridad social que con ellas se ejerce" 65 . Con tal objeto, se establece que en los casos de ingreso en centros o servicios del sistema público los usuarios vendrán obligados a declarar la situación patrimonial. Así, los usuarios que no abonen con su aportación económica mensual la totalidad del precio generan una deuda por la diferencia resultante, y para asegurar el cobro de la deuda se les exigirá la constitución de las garantías reales o personales precisas ${ }^{66}$. No obstante, la ejecución de este tipo de medidas plantea problemas prácticos que es preciso afrontar ${ }^{67}$.

Asimismo, conforme a los principios de solidaridad y redistribución, las aportaciones de los usuarios en centros residenciales se determinan de acuerdo con su capacidad económica. Para ello, por lo común, se fija una cantidad en función de un porcentaje de sus ingresos ${ }^{68}$, lo cual en ocasio-

${ }^{64}$ Ley de Galicia 4/1993 de Servicios Sociales -art. 79-; Ley de Asturias 7/1991 -art. 14.2-; Ley de Extremadura 2/1994-art. 23.1-; Ley de Canarias 3/1996 -art. 24-; Ley de Castilla-La Mancha 5/1995, de solidaridad -art. 31.2-; Ley de Andalucía 6/1999 -art. 22.3-. Vid., J.L. FUENTES NOGALES, "Reconocimiento de deuda", Ararteko, "El año internacional de las personas mayores", Los derechos no caducan con la edad: el año internacional de las personas mayores., San Sebastián, 1999, pp. 125 y ss.

65 Ley de Asturias 7/1991 -art. 14-; Ley de Extremadura 2/1994 -art. 23.1-; Ley de Canarias 3/1996 -art. 24-.

${ }^{66}$ Ley de Andalucía 6/1999 -art. 22.2-.

${ }^{67}$ Así, la Ley Foral de Navarra 17/2000, de 29 de diciembre, reguladora de la aportación económica de los usuarios a la financiación de los servicios por estancia en centros para la tercera edad, establece que la imposibilidad demostrada de constituir garantías no debe ser motivo, en ningún caso, de denegación de la prestación del servicio. Asimismo, cuando se haya constituido garantía sobre la vivienda y fuera preciso ejecutarla para el cobro de la deuda, esta se suspenderá mientras la vivienda sea necesaria para el uso propio por abandono de la residencia, cuando constituya el domicilio único del cónyuge, de los hijos que no formen parte de otra unidad familiar, o de otras personas cuya necesidad de la misma sea valorada por la Administración -art. 17-.

68 Así, la Ley Foral de Navarra 17/2000 establece que la aportación económica en ningún caso podrá alcanzar el 100 por 1000 de la renta del usuario -art. 7-. 
nes, si tal aportación no se mide correctamente, puede dar lugar a situaciones de agravio ${ }^{69}$.

Finalmente, es evidente que en caso de centros integrados en el sistema público de servicios sociales, la contribución financiera de los usuarios tiene la naturaleza de precio público, de modo que la Hacienda Pública ostenta para su cobro de las prerrogativas legalmente establecidas para los ingresos de Derecho Público ${ }^{70}$.

\subsubsection{Participación de los usuarios en el funcionamiento de los centros}

Generalizando un criterio ya previsto en la Ley estatal 13/1982, de 7 de abril, de Integración social de los minusválidos ${ }^{71}$, las Leyes autonómicas en materia de servicios sociales suelen proclamar la participación de los ciudadanos en los propios centros de servicios sociales, mediante las fórmulas que reglamentariamente se determinen ${ }^{72}$. Y en tal sentido, las autoridades han venido aprobando disposiciones en las que se ordena la elaboración y aprobación en las residencias públicas de reglamentos de régimen interior, con concre-

69 El Valedor do Pobo, en su Informe extraordinario "Situación de los ancianos en Galicia", junio 1994, p. 422, señalaba el agravio comparativo, frecuentemente denunciado, consistente en que, a la mayoría de los usuarios que pagan a la residencia el $75 \%$ de su pensión les viene quedando para sus gastos particulares menor cantidad de dinero que a los que pagan el $50 \%$, y eso, pese a que su pensión es un poco mayor. Por ello, se sugirieron fórmulas más equitativas, mediante una escala de precios más variada, que garantice a la vez dos aspectos: que el que tiene más ingresos pague más, pero sin que le quede para sus gastos particulares menor cantidad de dinero que al que paga menos.

${ }^{70}$ Expresamente, Ley de Castilla y León 5/2003 -art. 41-.

71 Según esta Ley -art. 4.3-, en los centros financiados, en todo o en parte, con cargo a fondos públicos, existirán órganos de control del origen y aplicación de los recursos financieros, con la participación de los interesados o subsidiariamente sus representantes legales, de la dirección y del personal al servicio de los centros, sin perjuicio de las facultades que correspondan a los poderes públicos. Igualmente, en 1990 el Defensor del Pueblo del Estado, en Informe especial sobre las residencias públicas y privadas de la tercera edad, manifestó: "En todas las Residencias públicas de la tercera edad habría de garantizarse la participación de los residentes, mediante la implantación de los correspondientes órganos de representación y participación”.

72 Sobre la parvedad y falta de concreción de los cauces participativos en las Leyes autonómicas sobre servicios sociales, vid. J.L. BELTRÁN AGUIRRE, "Los principios organizativos de la Administración social: Descentralización, participación, coordinación y cooperación”, Documentación administrativa núm. 271-272, 2005, p. 223. 
ción de derechos y deberes de los usuarios, y la constitución de órganos de participación de los usuarios de representación y participación de los usuarios en la marcha del centro (típicamente, Asamblea general y Junta o Consejo de Gobierno). Sin embargo, en la práctica, estos órganos a veces no llegan a constituirse o, lo que es más frecuente, su funcionamiento es harto irregular ${ }^{73}$.

Por último, en los centros públicos se está incorporando la práctica de la suscripción por parte del usuario y de la Administración de un contrato, con denominaciones diversas -de asistencia, de hospedaje o de alojamiento-, en el cual se especifican los derechos y deberes de ambas partes ${ }^{74}$. En todo caso, debe subrayarse que este instrumento no tiene el alcance del contrato que se celebra entre un cliente y un centro privado, pues la posición jurídica del usuario -como se ha dicho- ya está predeterminada en las leyes y normas reglamentarias, de modo que su empleo presenta más bien una virtualidad de carácter pedagógico y, sobre todo, para hacer efectivo el mencionado principio de atención individualizada, así como otros aspectos ${ }^{75}$.

\footnotetext{
${ }^{73}$ Vid. Valedor do Pobo, Informe extraordinario "Situación de los ancianos en Galicia", junio 1994, p. 401 y ss. En igual sentido, el Diputado del Común de Canarias, "Diagnóstico de la situación de los centros para personas mayores en Canarias", 2001, dirá que la mayoría de las residencias carecen de un órgano de representación de los usuarios o de los familiares, y los cauces de presentación de las quejas son inexistentes. Por su parte, la Defensora del Pueblo de Navarra, Informe especial al Parlamento de Navarra "La atención a la dependencia de las personas mayores en Navarra", marzo de 2005, p. 204, ha señalado: "La normativa de nuestra Comunidad promueve una cierta participación, aún con una concepción limitada y paternalista, pero hemos podido comprobar que no se cumple. No se le da valor por ninguno de los estamentos de las residencias: dirección, personal, ni los propios residentes”. Por ello esta Comisionado parlamentario propuso el establecimiento de órganos específicos de los usuarios que sean independientes de la dirección del centro, y donde los interesados puedan discutir libremente sus propuestas y planteamientos al margen del Consejo de Participación (p. 363).

${ }^{74}$ Ley de Asturias 7/1991 -art. 14.3-; Ley de Extremadura 2/1994 -art. 25.2-; Ley de Castilla-La Mancha 5/1995, de solidaridad -art. 31-.

${ }^{75}$ Como la determinación de las garantías que deban prestar los usuarios que tengan bienes, o las prescripciones cautelares que eviten la ocultación de los bienes (Ley de Asturias 7/1991 -art. 14.3-). Vid. J.M. ALONSO SECO, "El 'status' jurídico-administrativo del interno en centros de la red pública asistencial: derechos y obligaciones”, Documentación Administrativa, núm. 271, 2005, pp. $437-438$.
} 


\subsection{Régimen de los centros concertados}

\subsubsection{Entidades e instrumentos para la concertación de servicios}

La práctica totalidad de las leyes autonómicas sobre servicios sociales contemplan la posibilidad de prestar servicios sociales públicos mediante conciertos con la iniciativa privada ${ }^{76}$. De hecho, la política generalizada en el conjunto de las Comunidades Autónomas parece claramente orientada a animar a la iniciativa privada (no lucrativa y lucrativa, como se verá) a crear residencias de ancianos ofreciéndoles la posibilidad de un convenio o contrato, y desviar así de la Administración de la Comunidad la responsabilidad de implantarlas y gestionarlas directamente ${ }^{77}$.

En Andalucía, inicialmente, la Ley 2/1988, de 26 de diciembre, de Servicios Sociales, únicamente contempló la colaboración en el Sistema Público de Servicios Sociales de las entidades privadas sin ánimo de lucro -art. 25-. Este criterio tuvo que ser rectificado por la Ley 15/2001, de 26 de diciembre, por la que se aprueban medidas fiscales, presupuestarias, de control y administrativas, la cual eliminó la expresión "sin ánimo de lucro"78. Pero lo cierto es que, con fundamento en disposiciones reglamentarias, ya la Administración autonómica, empujada por la falta de recursos sociales, venía instando la colaboración de entidades con ánimo de lucro.

\footnotetext{
${ }^{76}$ Ley de Asturias 7/1991, de asistencia y protección del anciano; Ley 2/1994 de Extremadura de asistencia social geriátrica. El caso más significativo fue el de Navarra, que llegó a aprobar la Ley Foral 20/1985, de 25 de octubre de Conciertos en materia de Servicios Sociales, ahora parcialmente derogada, como apuesta en favor del concierto como forma indirecta de gestión de los servicios que se prestan en centros residenciales. La situación es, asimismo, similar en relación con el servicio de ayuda a domicilio. Vid. Tribunal de Cuentas, Informe de fiscalización de la gestión contractual realizada por las diputaciones provinciales, ejercicio 2002, respecto de los servicios de asistencia domiciliaria, núm. 662, de 2005.

77 Vid. J.M. ALONSO SECO- B. GONZALO GONZÁLEZ, La asistencia social y los servicios sociales en España, BOE, Madrid, 2000, pág. 178. Por su parte, Mª̊A. MARTÍNEZ ROMÁN- E. GUILLÉN SADABA -"La reorientación de los servicios sociales en los 80", en El Derecho y los servicios sociales, GARCÍA VILLALUENGA (Coord), Comares, 1997, p. 20- observan una oscilación exagerada entre los dos polos, el público y el privado, pasando de un énfasis inicial en lo público (entendiendo que responsabilidad pública equivalía a servicios sociales únicamente públicos), a la situación actual de privatización, en la que parece que todo tiene que hacerse a través se servicios privados, con el riesgo de disminución en la calidad de los servicios públicos. Sobre el papel del Estado y de la iniciativa privada en los servicios sociales para mayores, vid. Valedor do Pobo, en su Informe extraordinario "Situación de los ancianos en Galicia", junio 1994, pp. 513 y ss.
} 
Así, por Orden de 30 de agosto de 1996, de concertación de plazas con centros de atención especializada (BOJA núm. 113, de 1 de octubre de 1996), se contemplaron tres "modalidades de concertación de plazas" (se utiliza el término concertación en sentido amplio, como se verá a continuación): convenios con Entidades Locales, convenios con entidades privadas sin ánimo de lucro y contratos de gestión de servicio público, bajo la modalidad de concierto, cuando se trate de entidades privadas con ánimo de lucro ${ }^{79}$. De este modo, desde 1996 se admitía la colaboración con entidades con ánimo de lucro ${ }^{80}$.

El empleo de la figura del convenio no plantea problemas en las relaciones interadministrativas -art. 3.1.c ) Real Decreto Legislativo 2/2000, por el que se aprueba el Texto Refundido de la Ley de Contratos de las Administraciones Públicas (TRLCAP)-. En cambio, sí suscita dudas en el caso de las entidades privadas aún sin ánimo de lucro -art. 3.1.d) TRLCAP-, sobre todo, si se tiene presente que, en la práctica, la Administración hace un uso excesivo de la figura del convenio, que indudablemente le permite mayores márgenes

${ }^{78}$ Este criterio ya había sido explicitado en otras Comunidades Autónomas. Así, la Ley de Galicia 4/1993 de servicios sociales -art. 3-, introduce dos principios: por un lado, el llamado principio de "reconocimiento y apoyo a la iniciativa social", entendiendo por tal a la iniciativa privada sin ánimo de lucro, y, por otro lado, el llamado principio de "reconocimiento de la iniciativa privada con ánimo de lucro", a la que se reconoce expresamente que podrá concurrir a la prestación de los servicios sociales. En este sentido, la Ley catalana 4/1994, de Administración institucional, de descentralización, de desconcentración y de coordinación del sistema catalán de servicios sociales -art. 26.2-, habilitó a las Administraciones Públicas a concertar la gestión de servicios "con entidades privadas, preferentemente de iniciativa social", con lo cual no excluyó a las entidades lucrativas.

${ }^{79}$ Curiosamente, la Orden de 30 de agosto de 1996 fue objeto de una inmediata modificación, por Orden de 17 de octubre de 1996, es decir a los escasos días de su publicación (BOJA núm. 126, de 2 de noviembre de 1996). Asimismo, la Orden fue nuevamente modificada por Orden de 23 de diciembre de 2002 (BOJA núm. 6, de 10 de enero de 2003), con objeto de actualizar el coste real de las plazas. De otro lado, mediante Resolución de 24 de octubre de 1996 del IASS se aprobaron los modelos tipo de convenio y contrato, así como los modelos tipo de pliegos de condiciones (BOJA núm. 132, de 16 de noviembre de 1996).

${ }^{80}$ En el 2002 del total de 127 residencias concertadas por la Administración de la Junta de Andalucía, 112 eran gestionadas por entidades sin ánimo de lucro, mientras que 15 lo eran por entidades lucrativas. Datos extraídos del Informe de la Cámara de Cuentas de Andalucía sobre las residencias de mayores concertadas, correspondiente al ejercicio 2002.

${ }^{81}$ Con todo, la Cámara de Cuentas de Andalucía observó en el citado informe que en determinados supuestos se han suscrito convenios con entidades con ánimo de lucro, cuando correspondería la celebración de contratos de gestión de servicio público. 
de discrecionalidad ${ }^{81}$. Por el contrario, no existe razón alguna para reservar la figura contractual del concierto para las entidades con ánimo de lucro. Así, debe recordarse que el Real Decreto Legislativo 2/2000 -art. 156.c)-, por el que se aprueba el TRLCAP, al enumerar las modalidades de contratación de los servicios públicos, contempla: "Concierto con persona natural o jurídica que venga realizando prestaciones análogas a las que constituyen el servicio público de que se trate" ${ }^{2}$.

Cuestión distinta, y sorprendente, es la práctica detectada en alguna Comunidad según la cual las entidades lucrativas perciben mayor cantidad por sus servicios que las entidades sin ánimo de lucro ${ }^{83}$.

82 Vid., sobre todo ello, F.J. VILLAR ROJAS, "Formas de gestión de los servicios sociales: en particular, la vinculación de gestores privados al sistema público mediante conciertos y convenios", Documentación Administrativa, núm. 271, 2005, pp. 403 y ss., quien defiende que la condición sin ánimo de lucro de la entidad adjudicataria no permite excluir la concurrencia pública, sino que, en igualdad de condiciones en el concurso, la adjudicación favorezca a la entidad que carezca de ánimo lucrativo.

${ }^{83}$ Así lo ha puesto de manifiesto la Defensora del Pueblo de Navarra, Informe especial al Parlamento de Navarra "La atención a la dependencia de las personas mayores en Navarra", marzo de 2005, p. 122: "El Instituto Navarro de Bienestar Social concede mayores cuantías por plaza concertada a entidades de carácter lucrativo que a entidades sin ánimo de lucro. (...) A esto hay que añadir que no se establecen criterios objetivos sobre la calidad del servicio (por ejemplo: ratio de personal, cualificación, servicios ofrecidos, equipamiento material e infraestructural, etc.) que sirvan de base para fijar las cuantías de los conciertos. El simple hecho de ser una entidad con ánimo de lucro garantiza percibir una mayor cuantía en caso de que se conceda el concierto". 
Residencias concertadas en Andalucía (2002)

\begin{tabular}{|l|c|c|c|}
\hline PROVINCIA & $\begin{array}{c}\text { GESTIONADAS } \\
\text { POR ENTIDADES } \\
\text { SIN ÁNIMO } \\
\text { LUCRO }\end{array}$ & $\begin{array}{c}\text { GESTIONADAS } \\
\text { POR ENTIDADES } \\
\text { SIN ÁNIMO } \\
\text { LUCRO }\end{array}$ & TOTALES \\
\hline Almería & 8 & 2 & 10 \\
\hline Cádiz & 18 & 2 & 20 \\
\hline Córdoba & 14 & 4 & 18 \\
\hline Granada & 11 & 2 & 13 \\
\hline Huelva & 8 & - & 8 \\
\hline Jaén & 17 & 1 & 18 \\
\hline Málaga & 8 & - & 8 \\
\hline Sevilla & 25 & 2 & 27 \\
\hline Servicios centrales & 2 & 2 & 127 \\
\hline TOTAL & 112 & 15 & 4 \\
\hline
\end{tabular}

Fuente: Cámara de Cuentas de Andalucía

\subsubsection{La acreditación como requisito previo}

Como se señaló más arriba, algunas Comunidades Autónomas han ordenado un sistema dual de control administrativo, integrado por la autorización -ya tratada- y la acreditación ${ }^{84}$. En Andalucía, el Decreto 87/1996 establece que la acreditación tiene por finalidad garantizar que los centros a quienes se otorga reúnen los requisitos mínimos de calidad que se establezcan reglamentariamente ${ }^{85}$. Aun cuando esta disposición establece que pueden ser ob-

${ }^{84}$ La reciente Ley Foral de Navarra 15/2006, de 14 de diciembre, de Servicios Sociales, en lugar de acreditación, habla de "homologación administrativa" -art. 76-, pero la figura es la misma. Lo verdaderamente novedoso es que esta Ley exige también a los servicios de titularidad pública, independientemente de que sean gestionados directamente o por medio de una entidad de iniciativa privada, que deberán estar homologados -art. 80-.

85 De modo similar, el Decreto de Castilla y León 109/1993, de 20 de mayo, define a la acreditación como el acto por el cual la Administración Social reconoce mediante resolución, que el centro o servicio registrado reúne una especial garantía de calidad e idoneidad para los usuarios. 
jeto de acreditación los Servicios y Centros de Servicios Sociales dependientes de entidades "públicas y privadas" que pretendan concertar con la Administración o bien obtener el reconocimiento de la calidad de sus servicios, no se ordena claramente la sujeción a los requisitos de calidad de los centros de titularidad de la propia Administración autonómica, pues la norma parece referirse a los centros públicos de titularidad local ${ }^{86}$.

Los requisitos que se consideran atienden a aspectos tales como condiciones físicas y arquitectónicas, recursos humanos, atención ofrecida, sistema de participación, sistema contable, sistema de información a las Administraciones Públicas, etc. La acreditación se otorga por un plazo máximo de cuatro años, pudiendo ser suspendida o cancelada durante su vigencia y comporta -art. 30- una serie de obligaciones adicionales -como remisión anual de la memoria de actividades del centro y del balance económico del año anterior y de los presupuestos del año en curso, variaciones de las plantillas ${ }^{87}$.

Por tanto, los requisitos para obtener la autorización pueden calificarse de requisitos mínimos para que un centro pueda funcionar, con independencia de su integración en el sistema público, es decir, para que el centro sea "legal”. En cambio, los requisitos para la acreditación constituyen un plus de ca-

\footnotetext{
${ }^{86}$ Sobre la necesidad de someter a las exigencias legales tanto a los centros privados como públicos, vid. Centro de documentación y estudios, SIIS, Sistemas de autorización y acreditación de servicios residenciales para ancianos, San Sebastián, 1991.

${ }^{87}$ Por Orden de 1 de julio de 1997 (BOJA núm. 81, de 15 de julio de 1997) se reguló la acreditación de los centros de atención especializada a las personas mayores y personas con discapacidad. El objeto de esta disposición consistió en desarrollar las condiciones materiales y funcionales de calidad que deben exigirse para la acreditación de los centros de atención a las personas mayores (y con discapacidad). Tras diversos estudios de costes, la Orden fue modificada por Orden de 3 de julio de 2006 (BOJA núm. 142, de 25 de julio de 2006). Debe señalarse que, con anterioridad de dicha Orden de 1997, sorprendentemente no estaban determinados los requisitos para la acreditación, de modo que la Administración aplicaba por analogía una Resolución de 30 de Julio de 1993, del Instituto Andaluz de Servicios Sociales, por las que se determinan las condiciones técnicas que deben reunir los Centros de Atención Especializada para Personas con Minusvalías, para poder suscribir conciertos de plazas con dicho Instituto, con la consiguiente inseguridad jurídica e indefensión para los usuarios de los centros concertados. De nuevo, Andalucía no es un caso aislado en este sorprendente fenómeno de inactividad normativa. Así, el Procurador del Común de Castilla y León, Informe especial sobre "La atención residencial de la tercera edad en Castilla y León", Boletín Oficial de las Cortes de Castilla y León, núm. 223, 16 de mayo de 1998, p. 209, tuvo también que solicitar a la Administración autonómica a que procediera a la regulación de los requisitos específicos necesarios para la obtención de la acreditación de los centros y servicios de carácter social.
} 
lidad para que el centro pueda adherirse al sistema público de servicios sociales. Así, según el Decreto 87/1996, la acreditación (sólo) podrá ser solicitada a partir del momento en el que se haya obtenido la autorización -art. 28-. Podría decirse, en otros términos, que la acreditación representa una homologación de los Centros con un nivel de prestación de servicios lo suficientemente alto para que la Administración pueda emplearlos como colaboradores del sistema de Servicios Sociales ${ }^{88}$.

\subsubsection{Financiación de los centros concertados}

En Andalucía, el modelo de financiación de los centros concertados se basa en las aportaciones de los residentes ( $75 \%$ de sus ingresos líquidos anuales, excluidas las pagas extraordinarias, prorrateado por días sin superar el coste por plaza y día) y de la Administración autonómica (el resto del coste de la plaza con un máximo del $80 \%$ de éste). En el supuesto de que el centro perciba asignaciones o subvenciones públicas para el mantenimiento del mismo deberá deducirse del coste de cada plaza la cantidad prorrateada que corresponda a la misma. Las modificaciones normativas han tenido especial trascendencia en lo que concierne al coste de las plazas reservadas, siendo éstas las plazas concertadas y no ocupadas, bien porque se esté tramitando su ocupación o bien porque su titular se encuentre ausente "por permiso, fines de semana, vacaciones o internado en centro hospitalario" 89 .

${ }^{88}$ Defensor del Pueblo Andaluz, "Investigación sobre las Residencias de Ancianos Ilegales", Informe al Parlamento de Andalucía 1995, p. 932. Así, esta institución señaló: "la acreditación supone la exigencia de unas condiciones de calidad en la prestación de los servicios por parte de los Centros que supera el standard de calidad obligatorio para la concesión de la autorización".

${ }^{89}$ Con anterioridad a la Orden de 30 de agosto de 1996, el coste de la plaza reservada se había fijado en el $60 \%$ del coste de la plaza ocupada. Con la Orden de 30 de agosto de 1996, se limita el periodo financiado por la Administración para tramitar la ocupación a un máximo de 30 días y se establece su coste en el 50\% del de la plaza ocupada. Con la Orden de 5 de abril de 2000, se considera plaza reservada cuando "su titular se encuentre ausente por permiso no superior a 45 días naturales, fin de semana o internamiento en centro hospitalario". No obstante, a efectos económicos, la plaza reservada será considerada como ocupada "cuando su titular se encuentre ausente los fines de semana inferiores a cuatro días o cuando se encuentre internado en Centros hospitalarios". El coste también resulta modificado, fijándose nuevamente en el $60 \%$. En caso de no ocupación se mantiene el límite de 30 días. Pero lo cierto es que, según el informe de la Cámara de Cuentas de Andalucía, en las facturaciones presentadas por los centros no se tienen en cuenta las plazas reservadas por motivos distintos a que se esté tramitando su ocupación, es decir, por permiso, fin de semana o internamiento hospitalario. "Este último motivo sería lógico que apareciera con cierta frecuencia dada la edad de los resi- 


\subsubsection{Posición de los usuarios de centros concertados}

Asimismo, debe observarse que la designación de los beneficiarios de las plazas corresponde a la Administración, y el régimen aplicable a los centros debe garantizar a los beneficiarios ingresados en plazas concertadas "los mismos derechos establecidos para centros públicos dependientes de la Administración", sin que en ningún caso pueda existir discriminación alguna entre los beneficiarios ocupantes de plazas concertadas con la Administración y los demás residentes ${ }^{90}$.

A este respecto, es generalizado el criterio según el cual los centros concertados deben contar con un sistema de participación democrática de los usuarios o representantes legales en su funcionamiento ${ }^{91}$, si bien en la práctica el grado de cumplimiento efectivo de esta directriz es dudoso ${ }^{92}$.

dentes, la consideración en muchos de los casos de residente asistido y que la práctica totalidad de las vacantes que se producen tienen por causa el fallecimiento del residente. Ello supone que se estén facturando como ocupadas plazas reservadas". Pero, además, es una práctica que afecta también a la aportación de los residentes.

90 Orden de 30 de agosto de 1996 -arts. 10 y 11-. Como se señaló, por Orden de 21 de junio de 2006, se aprueba el Reglamento de Régimen Interior de los Centros Residenciales de Personas Mayores de titularidad de la Junta de Andalucía, el cual es aplicable a los centros residenciales para personas mayores de titularidad de la Junta de Andalucía. Obsérvese que la Orden de 30 de agosto de 1996 es un tanto ambigua, pues no establece que la normativa de las residencias públicas se aplique directamente a las concertadas, sino que los usuarios "tendrán los mismos derechos". Por ello, es acertada la sugerencia de J.M. ALONSO SECO, "El 'status' jurídico-administrativo del interno en centros de la red pública asistencial: derechos y obligaciones", Documentación Administrativa, núm. 271, 2005, p. 438, en el sentido de que los pliegos de condiciones de los conciertos especifiquen los derechos y deberes que asisten a los usuarios de centros concertados.

${ }^{91}$ Así se prevé en el modelo de pliego de condiciones previsto en la Resolución de 24 de octubre de 1996.

${ }^{92}$ El Justicia de Aragón señalaba en su informe especial "Calidad de vida de las personas mayores. Un supuesto especial: el maltrato", Zaragoza, 2004, p. 33: "La existencia de órganos de participación y representación de los usuarios de estos centros viene condicionado en gran medida por la capacidad de la residencia y el tipo de personas a las que atiende, especialmente en los centros privados. Es comentario común en este tipo de establecimientos que si los residentes son personas válidas suelen llevar una vida independiente sin tener, en ocasiones, mucha relación entre ellos; y si son personas asistidas, la limitación de sus capacidades suele ser un obstáculo serio para la constitución de este tipo de representaciones". 


\subsubsection{Relaciones Administración-centro concertado}

Por último, en los centros concertados a las potestades generales de inspección se suman unas facultades adicionales de supervisión derivadas del convenio o contrato suscrito entre la Administración y el centro concerta$\mathrm{do}^{93}$. Estas facultades tienen por objeto inmediato fiscalizar el fin de los fondos públicos que se destinan a sufragar la estancia de los usuarios, lo que en un sistema de concierto de plazas supone que la fiscalización no sólo alcanza a los aspectos o condiciones generales de la instalación o servicio -como sucede con los centros autorizados-, sino también a la calidad misma de los servicios que recibe, individualmente, cada usuario, dado que los usuarios designados por la Administración son usuarios de un servicio público ${ }^{94}$. Con todo, también aquí se ha observado una cierta pasividad por la Administración competente ${ }^{95}$.

${ }^{93}$ Así, la obligación de los centros acreditados de remitir anualmente la memoria de actividades del centro, y de comunicar las variaciones en la plantilla de personal y, sobre todo, la sujeción de los centros acreditados al sistema de control de calidad fijado por la Administración -art. 7 Orden de 1 de julio de 1997-. Por su parte, la Orden de 30 de agosto de 1996 no refleja adecuadamente esta especial posición de la Administración, pues se limita a establecer que la Administración podrá efectuar inspecciones y visitar el centro en cualquier momento para constatar que las instalaciones, la dotación de personal, así como la prestación de servicios, se ajustan a lo estipulado en el concierto y a la normativa autonómica -art. 12-.

${ }^{94}$ Así, la Ley General de Sanidad -art. 94- establece que la Administración ejercerá funciones de inspección sobre aspectos sanitarios, administrativos y económicos relativos a cada enfermo atendido por cuenta de la Administración Pública en los centros privados concertados. Esta especial posición de la Administración es aún más expresiva en algunas normas. Así, Ley 4/1997, de 9 de julio, de Prevención y Asistencia en materia de drogas en Andalucía, establece que la totalidad de los centros y servicios de atención de drogodependientes gestionados por entidades que suscriban conciertos o convenios o se beneficien de ayudas de la Administración autonómica tendrá, en cuanto al desarrollo de programas de intervención, una dependencia funcional del órgano administrativo al que se adscriba el plan autonómico sobre drogas -art. 33.4-.

${ }^{95}$ Según el mencionado informe de la Cámara de Cuentas de Andalucía de residencias para mayores concertadas, relativo al ejercicio de 2002, los planes de inspección no habían contemplado la fiscalización del mantenimiento de los requisitos relativos a la acreditación de los Centros concertados. Es decir, en las visitas de inspección, con independencia de que el centro estuviera o no acreditado, sólo se ha revisado el cumplimiento de los requisitos mínimos materiales y funcionales, aquellos que son exigidos a efectos de la mera autorización del centro. Finalmente, el plan general de inspección para el año 2005 sí contempló la verificación de los requisitos propios de la acreditación, como las condiciones físicas y arquitectónicas, los recursos humanos y organización de personal y la atención ofrecida e índole de la prestación. 


\subsection{Los centros privados no concertados}

Durante una primera etapa de la política autonómica en materia de servicios sociales, la Administración pareció ignorar la actuación de la iniciativa privada lucrativa en este campo y, en particular, en el sector de los centros residenciales para personas mayores. Ya se ha señalado cómo en Andalucía la Ley 2/1988 únicamente contemplaba la colaboración con la iniciativa privada sin ánimo de lucro. Pero esta inactividad tuvo otras manifestaciones más llamativas. Así, también se ha señalado cómo hasta 1996 no se aprobó una norma que estableciera los requisitos materiales y funcionales a cumplir por los centros privados no concertados, y, relacionado con esto, la actividad de inspección sobre centros no concertados ha sido durante mucho tiempo prácticamente inexistente. Restringir la política de fomento a las entidades sin ánimo de lucro puede ser más o menos atendible ${ }^{96}$, pero desde luego es inexcusable la inactividad normativa y de control sobre las entidades lucrativas, pues la pasividad de la Administración competente ha dejado a los usuarios de estos centros privados en manos exclusivamente de la genérica política de defensa de los consumidores y usuarios.

En este sentido, el Defensor del Pueblo ha llamado la atención acerca de la necesidad de ejercer un control sobre las condiciones de contratación que, en ocasiones, imponen las entidades privadas a los solicitantes de asistencia, y que pueden resultar abusivas o contrarias a sus derechos ${ }^{97}$. A este respecto, debe subrayarse la sujeción de los centros privados -como los públicos-, a la legislación de consumidores y usuarios, que protege -entre otras cosas- los legítimos intereses económicos de los usuarios, en particular frente a la inclusión de cláusulas abusivas en los contratos (art. 2 Ley 26/1984, de 19 de julio, General para la Defensa de los Consumidores y Usuarios). En este sentido, la Ley de Andalucía 6/1999 dispuso que las Administraciones Públicas garanti-

\footnotetext{
${ }^{96}$ Basta recordar la activa política de fomento que lleva a cabo la Administración autonómica en los más dispares sectores económicos, como el turismo o el comercio, con independencia del carácter lucrativo o no de sus beneficiarios.

${ }^{97}$ Defensor del Pueblo, Informe a las Cortes Generales 2001, p. 363: "Así, desde esta Institución, se instó a la actuación de la Comunidad de Madrid, al tener conocimiento del contenido de la cláusula existente en el documento de liquidación de contrato de residencia, suscrito con una entidad geriátrica, en el que se señalaba expresamente la renuncia a formular denuncia por cualquier concepto, ante los organismos de la Administración central o autonómica. Esta cláusula, aún siendo nula y careciendo de validez alguna, resulta improcedente al intentar comprometer con ella al usuario o sus familiares (0010374)".
} 
zarán el respeto de los derechos que corresponden a las personas mayores como consumidores y usuarios, especialmente en relación a las ofertas comerciales dirigidas específicamente a este sector de la población -art. $48{ }^{98}$.

En esta línea, aun cuando rige la regla general de la libertad de precios, en algunas Comunidades Autónomas se establece que los precios deben ser puestos en conocimiento de la Administración, con objeto de que se pueda transmitir a toda la red de servicios sociales de la Comunidad Autónoma ${ }^{99}$. Además, alguna Ley sectorial añade que la Administración procurará disponer semestralmente la publicación de los precios en el boletín oficial de la Comunidad Autónoma ${ }^{100}$.

De otra parte, debe señalarse que, en algún caso, se prevé expresamente la posibilidad de que la Administración pueda excepcionalmente hacer uso de servicios no vinculados o no incluidos en $\operatorname{conciertos}^{101}$, y lo cierto es que las circunstancias pueden obligar a acudir a este recurso -por ejemplo, en caso de clausura de un centro clandestino -. Para estos casos excepcionales, sería conveniente articular legalmente un deber de colaboración de los agentes privados.

Por último, puede consignarse la posibilidad existente en algunas Comunidades Autónomas de que los ciudadanos puedan obtener, de modo subsidiario al recurso público, prestaciones económicas de la Administración para contribuir a la financiación de centros privados no concertados, es decir ajenos a la red pública ${ }^{102}$. No obstante, salvo alguna Comunidad en la cual el im-

98 Vid. L. ORTEGA ÁLVAREZ, "Servicios públicos y usuarios de de servicios”, Documentación Administrativa, núm. 271-272, 2005, p. 167.

${ }^{99}$ Ley de Galicia 4/1993 de servicios sociales -art. 31-. La Ley de Asturias 7/1991, de asistencia y protección al anciano, establece que la información sobre precios debe realizarse anualmente durante el mes de enero, y cualquier modificación de los precios que pretenda introducirse a lo largo del año deberá ser, asimismo, notificada, al menos con un mes de antelación a su implantación, a los usuarios y a la Administración -art. 11-. En los mismos términos, Ley de Extremadura 2/1994 -art. 23.3-.

${ }^{100}$ Ley de Asturias 7/1991 -art. 12-.

${ }^{101}$ Ley de Castilla y León 5/2003 -art. 36.3-.

102 Así, en Andalucía, cada año la Consejería competente en la materia viene ofertando ayudas individuales para la asistencia a centros residenciales para personas mayores. Así, la Orden de la Consejería para la Igualdad y el Bienestar Social de 1 de febrero de 2006, por la que se regu- 
porte de esta prestación se encuentra determinado en la Ley ${ }^{103}$, en general, se trata de ayudas de carácter discrecional y eventual. Así, el Defensor del Pueblo Andaluz ha señalado que el carácter discrecional de las subvenciones, cuya concesión se hace depender de la existencia de disponibilidad presupuestaria, y el carácter temporal de las mismas, las convierten en un recurso igualmente ineficaz e inseguro en el tiempo ${ }^{104}$.

\subsection{La insuficiente y desigual cobertura de los sistemas públicos de servicios sociales y sus consecuencias}

\subsubsection{Las (interminables) listas de espera}

El nivel de cobertura pública de plazas en centros residenciales ha sido y sigue siendo muy deficiente. El Plan Gerontológico Estatal de 1993 fijó, para un primer tramo, un objetivo de cobertura del 3,5\% por cada cien personas mayores de 65 años, que a su vez ya era modesto, para en el siguiente tramo llegar al 5\%, que es la media de plazas disponibles en el conjunto de la UE, y la tasa de cobertura recomendada por la OMS. Y si bien es cierto que desde el Plan Gerontológico de 1993 se ha hecho un aceptable esfuerzo en el desarrollo de equipamientos residenciales, este incremento de plazas ofertadas apenas ha supuesto una aumento en la ratio de cobertura -apenas 1 punto-, debido a que la expansión en la creación de este recurso ha corrido paralela al aumento del número de personas mayores de 65 años ${ }^{105}$.

Asimismo, el crecimiento operado en estos años, además de insuficiente, se ha realizado de manera desordenada, con grandes desequilibrios territo-

lan y convocan subvenciones en el ámbito de la Consejería para el 2006 (BOJA núm. 31) establece que este tipo de subvenciones tiene por objeto complementar la financiación de la atención residencial de personas mayores en situación de dependencia. Entre los requisitos para obtener esta ayuda se encuentra haber solicitado el ingreso, y no haber rechazado plaza, en su caso, en centro residencial que dependa de la Administración de la Junta de Andalucía -art. 95-.

${ }^{103}$ La ordenación más completa es la contenida en la Ley Foral de Navarra 17/2000, de 29 de diciembre, reguladora de la aportación económica de los usuarios a la financiación de los servicios por estancia en centros para la tercera edad.

104 Defensor del Pueblo Andaluz, Informe al Parlamento de Andalucía 2006, p. 673.

105 Ciertamente este Plan tuvo la virtud de contribuir de manera decisiva a un cambio conceptual en la consideración de las necesidades de las personas mayores, pero las previsiones contenidas en el mismo estuvieron muy lejos de cumplirse. Defensor del Pueblo, La atención sociosanitaria en España: perspectiva gerontológica y otros aspectos conexos, 1999, pp. 128-130. 
riales, que se traduce en una falta de equidad en el acceso a un recurso de tanta importancia como las residencias ${ }^{106}$. Además, se siguen apreciando un importante desajuste entre el tipo de plazas residenciales públicas y la demanda existente, pues aún es elevado el porcentaje de plazas para personas con autonomía en detrimento de las personas dependientes ${ }^{107}$.

Ciertamente se aprecia un incremento en los últimos años, pero es mínimo, mientras que la demanda es explosiva.

Evolución del índice de cobertura en España

\begin{tabular}{|c|c|c|c|}
\hline AÑO & $\begin{array}{c}\text { Plazas públicas más } \\
\text { concertadas }\end{array}$ & Plazas privadas & Total \\
\hline 1999 & 1,15 & 1,79 & 2,95 \\
\hline 2003 & 1,46 & 2,00 & 3,46 \\
\hline 2006 & 1,76 & 2,23 & 3,99 \\
\hline
\end{tabular}

Fuente: IMSERSO, Observatorio de personas mayores, Guía 2004 de residencias para personas mayores e Informe 2006

${ }^{106}$ En Andalucía en concreto, el Plan de Servicios Sociales de Andalucía 1993-1996, en su objetivo 4.1.4.10, se planteó ampliar progresivamente el número de plazas residenciales de ancianos hasta incrementar la cobertura a una ratio de 3.5 plazas por 100 personas mayores. Acceder a la cobertura propuesta por el Plan representaría disponer en torno a 32.000 plazas de residencias de ancianos, sin embargo las plazas públicas o financiadas con fondos públicos están alrededor de las 9.000 .

${ }^{107}$ La Defensora del Pueblo de Navarra, Informe especial al Parlamento de Navarra "La atención a la dependencia de las personas mayores en Navarra”, marzo de 2005, p. 128, señalaba que a pesar de que el número de plazas existente para válidos y asistidos es muy parecido, el número de personas esperando a plaza asistida es 2,20 veces superior al de plaza de válido. 
Índice de cobertura por Comunidades Autónomas

\begin{tabular}{|l|c|c|c|}
\hline $\begin{array}{l}\text { Comunidad } \\
\text { autonóma }\end{array}$ & $\begin{array}{c}\text { Tasa plazas } \\
\text { públicas y } \\
\text { concertadas }\end{array}$ & $\begin{array}{c}\text { Tasa plazas } \\
\text { privadas }\end{array}$ & TOTAL \\
\hline Andalucía & 1,14 & 1,57 & 2,71 \\
\hline Aragón & 2,20 & 3,42 & 5,62 \\
\hline Asturias & 1,53 & 2,52 & 4,05 \\
\hline Baleares & 1,45 & 1,42 & 2,87 \\
\hline Canarias & 1,50 & 1,71 & 3,21 \\
\hline Cantabria & 2,20 & 2,09 & 4,29 \\
\hline Castilla y León & 2,08 & 4,21 & 6,29 \\
\hline Castilla La Mancha & 2,44 & 3,26 & 5,70 \\
\hline Cataluña & 1,85 & 2,63 & 4,48 \\
\hline C. Madrid & 2,11 & 2,90 & 5,01 \\
\hline C. Murcia & 0,90 & 1,21 & 2,11 \\
\hline C. Valenciana & 1,93 & 1,00 & 2,93 \\
\hline Extremadura & 2,37 & 1,98 & 4,35 \\
\hline Galicia & 1,06 & 1,32 & 2,38 \\
\hline Navarra & 1,71 & 3,47 & 5,19 \\
\hline País Vasco & 2,37 & 1,50 & 3,87 \\
\hline La Rioja & 1,88 & 2,91 & 4,79 \\
\hline MEDIA & 1,76 & 2,23 & 4,00 \\
\hline
\end{tabular}

Fuente: IMSERSO, Las personas mayores en España 2006. No se incluyen en esta relación las plazas en viviendas tuteladas y otros sistemas alternativos de alojamiento. 
Plazas públicas más privadas en Andalucía

\begin{tabular}{|l|c|c|c|}
\hline PROVINCIA & $\begin{array}{c}\text { Mayores de } \\
65 \text { años }\end{array}$ & № total plazas & $\begin{array}{c}\text { Tasa } \\
\text { cobertura }\end{array}$ \\
\hline Almería & 71.218 & 1254 & 1,76 \\
\hline Cádiz & 134.656 & 2805 & 2,08 \\
\hline Córdoba & 128.656 & 2292 & 1,78 \\
\hline Granada & 132.234 & 1607 & 1,21 \\
\hline Huelva & 69.623 & 1106 & 1,58 \\
\hline Jaén & 112.605 & 2024 & 1,79 \\
\hline Málaga & 179.830 & 3643 & 2,02 \\
\hline Sevilla & 217.318 & 2593 & 1,19 \\
\hline
\end{tabular}

Fuente: IMSERSO y CESIC 2004

La falta de cobertura por parte de la Administración de plazas residenciales ha sido denunciada reiteradamente por los comisionados parlamentarios. El Defensor del Pueblo del Estado ya en un Informe especial de 1990 instó a las Administraciones Públicas a acentuar los esfuerzos para cubrir esta carencia, mediante la creación de plazas en centros propios o la cooperación con el sector privado, a través de la aplicación de medidas como la acción concertada y la técnica subvencional ${ }^{108}$.

En Andalucía, como puede verse en la tabla comparativa del conjunto de las Comunidades Autónomas, la situación es especialmente deficitaria. Sin embargo, como ha señalado el Defensor del Pueblo Andaluz, transcurridos más dos décadas desde que la Comunidad Autónoma tiene atribuidas competencias en esta materia, el problema de la carencia de centros residenciales para la tercera edad no puede achacarse a una coyuntura económica o social, pues ejercicios presupuestarios han existido para enderezar la situación ${ }^{109}$. Más

\footnotetext{
108 Igualmente, el Informe del Senado, La situación de las residencias de la tercera edad en España y alternativas a las mismas desde la perspectiva actual, 1989, p. 12682, urgió a las Administraciones Públicas competentes en la materia a que coordinaran sus esfuerzos en la creación de las plazas necesarias para lograr cubrir lo que la UE considera óptimas.

109 Defensor del Pueblo Andaluz, Informe al Parlamento de Andalucía 1999, p. 809. Asimismo, en el Informe al Parlamento de Andalucía 2003, se puede leer: "En lo que a recursos sociales o sociosanitarios se refiere es un tema ya recurrente aludir a la insuficiencia de las plazas residenciales y
} 
aún, los poderes públicos no sólo no se han dotado de los recursos necesarios para atender esta emergente realidad, sino que ni siquiera se han invertido los recursos que estaban comprometidos para esta finalidad ${ }^{110}$.

Un claro exponente de esta situación son las continuas quejas a los comisionados parlamentarios de ciudadanos que no ven satisfechas sus demandas de ingreso en un centro residencial, a pesar de encontrarse en situaciones a veces dramáticas, viéndose relegados a las interminables "listas de espera" -hasta tres años se necesitan para ingresar en algunas residencias de asistidos ${ }^{111}$. Así, el Defensor del Pueblo dirá en relación con su actividad correspondiente al 2002:

"No es infrecuente que los afectados se dirijan al Defensor del Pueblo, tras permanecer dos o tres años en lista de espera para acceder a un centro residencial, describiendo situaciones de notable deterioro que pese a las sucesivas revisiones, con incremento de la puntuación en el correspondiente baremo, no reciben respuesta favorable por carencia de plazas"112.

en Centros de Día, así como de las alternativas teleasistencia y ayuda a domicilio, recursos todos ellos cuya necesidad se impone progresivamente conforme se acentúa el grado de dependencia de los mayores por su edad y patologías asociadas a esta circunstancia que se agravan cuando hay carencia de recursos económicos y/o de apoyo familiar". Pero la queja vuelve a reiterarse en el Informe al Parlamento al Parlamento de Andalucía 2004, p. 870, en el que se solicita a la Administración que se incremente sustancialmente el número de plazas al objeto de equilibrar en la medida de lo posible la demanda asistencial. En todo caso, la situación es general en el conjunto de España. Así, el Arateko señaló, en la ponencia "La Protección de los Derechos de las Personas Mayores" presentada por en las XIV Jornadas de Coordinación de Defensores del Pueblo, que los recursos de plazas residenciales, ayuda a domicilio, viviendas tuteladas, centros de día, etc. aún están por debajo de los propios objetivos del Plan Gerontológico.

${ }^{110}$ Defensor del Pueblo Andaluz, Informe al Parlamento de Andalucía 1997.

111 Como las que describe el Defensor del Pueblo Andaluz, Informe al Parlamento de Andalucía 1999, pp. 806 y ss, en las que la Administración se limita a contestar que hay una lista de espera de 1290 solicitudes. No obstante, se observan diferencias notables en el cómputo de las listas de espera. Así, el Defensor del Pueblo Andaluz, en su Informe al Parlamento de Andalucía 2001, pp. 840 y ss., evaluó en 130.000 los ancianos en listas de espera para ingresar en residencia y sólo se oferta una plaza de residencia para cada 8 mayores dependientes. Por su parte, según datos del Servicio de Mayores de la Junta de Andalucía, a principios de 2002 la lista de espera era de un total de 7.232 personas, mientras que la finalización del año la lista de reserva había ya ascendido a 7.874 personas. Lo cierto es que, a diferencia de lo que sucede con las listas de espera del sistema sanitario donde existe una prescripción profesional que determina la necesidad del recurso asistencial, las listas de espera del recurso residencial son exclusivamente en función de las solicitudes de demanda del mismo.

112 Defensor del Pueblo, Informe a las Cortes Generales 2002, p. 376. Igualmente, Defensor del Pueblo, Informe a las Cortes Generales, 2000, BOCG, 8.10.2001, Serie A, núm. 201, p. 134. 
Con frecuencia, se trata de casos en los que se acredita sobradamente la situación de necesidad del interesado, de modo que la denegación del recurso obedece exclusivamente a la limitación de medios. Pero, como ha señalado el Defensor del Pueblo Andaluz, "la obtención de una puntuación significativamente elevada por parte del interesado, lejos de resultar meramente indicativa de esa natural limitación de medios, lo que revela es una absoluta insuficiencia de los instrumentos que la Administración pone al servicio de la satisfacción del derecho a la protección social de los ciudadanos, hasta el punto de que situaciones que se manifiestan gravísimas en virtud de la puntuación obtenida, permanecen desasistidas"113.

En su informe correspondiente al año 2005, el Defensor del Pueblo señalaba lo siguiente:

"En los escritos dirigidos a esta Institución se plantean diversas cuestiones, entre las que destacan, por su número y gravedad de la situación, las demandas de atención residencial. La notable diferencia entre el número de solicitudes y las plazas disponibles, aun cuando el incremento del número de éstas es constante, conlleva que cada vez la puntuación necesaria, para el acceso a las residencias públicas, sea mayor. Estos datos producen en algunos ciudadanos un efecto disuasivo, hasta el punto de que se dirigen al Defensor del Pueblo antes de haber iniciado la tramitación ante la Administración competente"114.

Pero esta insuficiencia de plazas no siempre obedece a la falta de infraestructuras. Así, se han denunciado casos de plantas vacías en residencias públicas por falta de personal necesario para atenderlas ${ }^{115}$.

113 Defensor del Pueblo Andaluz, Informe al Parlamento de Andalucía 1999, p. 812. Varios años después, en el Informe al Parlamento de Andalucía 2006, p. 672, la institución vuelve a enfrentarse a situaciones similares: "nos encontramos con una anciana octogenaria, enferma, totalmente dependiente y con escasísimos recursos económicos, de la que no se cuestiona su necesidad de estar ingresada en una Residencia donde la puedan atender adecuadamente y que lleva en lista de espera casi cuatro años (p. 673).

${ }^{114}$ Defensor del Pueblo, Informe a las Cortes Generales 2005, p. 504. Las referencias pueden multiplicarse. Así, en el Informe a las Cortes Generales 2001, p. 362, se dirá: "A pesar del interés demostrado por las administraciones interesadas en este asunto, las quejas que continuamente se dirigen al Defensor del Pueblo, continúan mostrando un panorama desalentador, en cuanto a las carencias que sufren los ciudadanos. Entre otros aspectos, se hace mención a que la notoria insuficiencia de recursos y de estructuras para estas personas, conlleva que la carga asistencial recaiga en las familias, que encuentran serias dificultades para prestar la atención que sus familiares precisan”.

115 Defensor del Pueblo Andaluz, Informe al Parlamento de Andalucía 1995, p. 918. 
Ni que decir tiene que la situación se agrava más aún si cabe cuando a la dependencia se añade alguna otra circunstancia como una demencia senil o el mal de Alzheimer ${ }^{116}$.

\subsubsection{Los criterios de admisión: el muro de los baremos}

La diferentes Comunidades Autónomas, en ejercicio de sus competencias, han aprobado sus propios baremos de acceso, incluyendo items similares -salud, dependencia, situación sociofamiliar, económica, condiciones de la vivienda, reagrupamiento familiar-, pero concediendo prioridad y peso diferente a cada uno de ellos ${ }^{117}$. La variedad es notable, sobre todo, en la valoración de la situación económica: algunas reglamentaciones establecen un tope de ingresos para acceder al servicio públicos, otras no; los instrumentos de evaluación de los ingresos son diferentes -cómputo de personas con discapacidades, que vivan solas, del patrimonio inmueble....- ${ }^{118}$.

116 Defensor del Pueblo Andaluz, Informe al Parlamento de Andalucía 1997, pp. 775, 786, 871 y 876. En general, el aumento progresivo del número de ancianos, las propias condiciones psicofísicas derivadas de la edad, las condiciones de las viviendas, la baja renta per cápita de los ancianos andaluces y los propios cambios sociales, hacen que un alto porcentaje de ancianos van a necesitar ayuda y cuidados personales.

117 Así, la Ley de Asturias 7/1991 dispuso que la prioridad en las admisiones vendrá determinada por la valoración conjunta de las circunstancias personales y familiares del solicitante, recursos económicos, condiciones de habitabilidad de las viviendas, abandono o soledad, así como por sus condiciones físicas, psíquicas y sociales, de acuerdo con los criterios y conforme al procedimiento que reglamentariamente se determine -art. 13-. En términos casi idénticos, la Ley de Extremadura 2/1994 -art. 24-. De modo similar, la Ley de Canarias 3/1996 establece que la prioridad en las admisiones y el tipo de recurso que habrá de prestar servicios a cada usuario, vendrán determinados por la valoración de las circunstancias personales y familiares, situación de abandono o soledad, condiciones físicas, psíquicas y sociales y recursos económicos del solicitante, de conformidad con el procedimiento y los criterios que reglamentariamente se determinen -art. 22-. No obstante, en algunas Comunidades ha seguido vigente hasta hace bien poco la Orden del Ministerio de Trabajo y Seguridad Social de 8 de enero de 1986, por la que se aprobaron los baremos de admisiones, traslados y permutas en los centros residenciales para la tercera edad del antiguo INSERSO de la Seguridad Social, como es el caso de Castilla y León, en virtud de la Disposición Transitoria Segunda del Decreto 2/1998, de 8 de enero, por el que se aprobó el Reglamento General de la Gerencia de Servicios Sociales (modificado por Decreto 82/2007, de 19 de julio).

118 En Andalucía el Decreto 28/1990, de 6 de febrero, por el que se establecen los requisitos para ingreso y traslado en residencias para la tercera edad, determina que la valoración de los correspondientes expedientes se hará de conformidad con los baremos vigentes, siendo aún de apli- 
Pero, en todo caso, como una clara consecuencia de la escasez de recursos sociales públicos - de titularidad pública y concertados-, las Administraciones competentes aprueban unos baremos extraordinariamente rigurosos (el llamado "muro de los baremos"). En efecto, los baremos suelen establecer requisitos tan rigurosos para poder acceder a los servicios públicos que el destino final de las solicitudes suele ser una interminable lista de espera.

Así, el Defensor del Pueblo Andaluz ha declarado: "La rigidez de los criterios establecidos viene condicionada por dos elementos determinantes: la escasez de plazas y el enorme volumen de la demanda". De este modo, debe subrayarse la radical diferencia que se produce en el modo de acceso cuando los ciudadanos se colocan frente al sistema de servicios sociales que cuando lo hacen ante cualquiera otro de nuestros sistemas de protección consolidados (educación, sanidad, pensiones). En el primer caso, la posición que se adopta es la de "solicitante de una ayuda", que la Administración discrecionalmente autorizará o denegará, mientras que, en cualquiera de los otros sistemas, el papel que se juega es el de ciudadanos que ejercen un derecho ${ }^{119}$.

La existencia de requisitos de acceso que nada o poco tienen que ver con la circunstancia objetiva de "necesitar ayuda para las actividades de la vida diaria” se plantea en dos direcciones seriamente cuestionables:

- Por una parte, suele penalizarse la existencia de un familiar que esté asumiendo el cuidado del anciano, lo que resulta verdaderamente paradójico e injusto para las familias, que observan atónitas cómo a su generosidad y entrega se responde por la Administración con una puntuación negativa en el baremo, es decir, los propios poderes públicos incentivan conductas de abandono.

cación en esta Comunidad Autónoma la Orden del Ministerio de Trabajo y Seguridad Social de 8 de enero de 1986. No obstante, hay dos salvedades: de un lado, en la variable "Otras circunstancias" se incluye la de residencia en la Comunidad Autónoma de Andalucía con un montante de 40 puntos, y, de otro lado, también fue modificada la variable relativa a la situación económica, tomando en consideración la totalidad de ingresos del solicitante y su cónyuge o pareja.

${ }^{119}$ Así, el Defensor del Pueblo, en el Informe La atención sociosanitaria en España: perspectiva gerontológica y otros aspectos conexos, 1999, p. 132, declaraba: "Urge, pues, reconocer que las necesidades de atención continua que requieren las personas mayores dependientes es de naturaleza equiparable a tener una pensión o recibir atención sanitaria”. 
- Por otra parte, porque alcanzar un determinado (y escaso) nivel de renta suele ser motivo de exclusión. De este modo, las clases medias se encuentran ante una nueva paradoja. Se les deniega el servicio público por sobrepasar el nivel de renta establecido en los baremos (son consideradas ricas), y cuando acuden en busca de un servicio privado, no pueden pagarlo (son y se sienten pobres) ${ }^{120}$. Ni que decir que la perversión del sistema de acceso a los servicios sociales resulta tan flagrante que cada vez es más habitual que muchas familias decidan falsear su auténtica situación -fingen la existencia de mala relación familiar, ocultan o falsean el nivel de renta...-. La tendencia debería ser la pérdida del peso del factor económico en la asignación del recurso -sobre todo si se tiene en cuenta que no es gratuito-, primando la situación de dependencia o fragilidad de la persona. Y la eliminación de los topes de ingresos para acceder al sistema de servicios sociales ${ }^{121}$.

En este sentido, en relación con una solicitud del servicio de ayuda a domicilio, el Defensor del Pueblo Andaluz señaló que, en ningún momento, la falta de recursos económicos describe a los colectivos destinatarios del servicio de ayuda a domicilio, sino que es la autonomía del individuo para realizar las actividades de la vida diaria la que debe tenerse en cuenta, y valorar para decidir la concesión de la ayuda a domicilio, y no circunstancias independientes a ella, como lo es la situación económica de los solicitantes. Lo que sí puede determinar la capacidad económica es la contribución del usuario en la financiación del servicio, siempre que quede garantizado que las familias con rentas inferiores acceden de forma gratuita. De este modo, se cumpliría el carácter universal de este servicio ${ }^{122}$. Y llevado a sus últimas consecuencias, este criterio la necesidad de asistencia del afectado, debería llevar a reservar el re-

${ }^{120}$ En este sentido, en la investigación del Justicia de Aragón, se puso de manifiesto que existe un considerable número de personas pertenecientes a una clase media que no tienen acceso a residencia pública ni a ningún tipo de ayuda por parte de la Administración, ni pueden optar por una residencia privada con un mínimo de condiciones (Informe especial "Calidad de vida de las personas mayores. Un supuesto especial: el maltrato”, Zaragoza, 2004, p. 31).

${ }^{121}$ Defensor del Pueblo, La atención sociosanitaria en España: perspectiva gerontológica y otros aspectos conexos, 2000, p. 145.

${ }^{122}$ Defensor del Pueblo de Andalucía, Informe al Parlamento de Andalucía 1998, p. 894. En este sentido, la Defensora del Pueblo de Navarra, Informe especial al Parlamento de Navarra "La atención a la dependencia de las personas mayores en Navarra", marzo de 2005, p. 132, señaló: "Los baremos que se utilizan y, principalmente, la finalidad de éstos nos indican que la gestión de las 
curso institucional a las personas dependientes, reconduciendo el apoyo de los llamados ancianos válidos a otros recursos sociales ${ }^{123}$.

En esta línea de revisión de los criterios en la asignación del recurso residencial se sitúa la Orden de la Junta de Andalucía de 22 de diciembre de 2006, con la finalidad de priorizar la institucionalización de los solicitantes que lo precisen por su situación de dependencia y no sea posible su cuidado en el propio entorno ${ }^{124}$.

Por su parte, el Defensor del Pueblo del Estado ha señalado la situación especial que se plantea cuando es un único hijo el que ha de responsabilizarse de sus padres dependientes, por la gran dedicación que éste debe otorgar a los mismos para atender adecuadamente a sus necesidades. Esta circunstancia no suele reflejarse entre las prioridades, sin tener en cuenta la dificultad añadida de no poder compartir dichas responsabilidades con otros familiares $^{125}$. Asimismo, también se ha cuestionado desde esta institución la circunstancia de que si el solicitante debido a la lista de espera ingresa en una residencia privada, pierde puntuación para el acceso al recurso público ${ }^{126}$.

listas de espera no está orientada a dar prioridad a las personas con menos capacidad de autovalimiento, ya que el baremo económico es el decisivo para poder acceder a una plaza. La valoración de la dependencia se utiliza únicamente para saber a qué tipo de plaza accede cada usuario, sin garantizar un acceso preferente. Estos datos nos indican que, con la organización actual del acceso a los recursos, no se garantiza que tengan prioridad las personas más necesitadas, entendiendo por necesidad la dependencia tanto física como psíquica".

${ }^{123}$ Justicia de Aragón, Informe especial "Calidad de vida de las personas mayores. Un supuesto especial: el maltrato", p. 31.

${ }^{124}$ Hasta esta disposición, la valoración de la situación médica, tanto física como psíquica, del solicitante estaba sujeta a una limitación máxima en la puntuación. Pero las exigencias de la demanda real, así como la próxima aplicación del sistema de atención a la dependencia, han obligado a eliminar las mencionadas limitaciones, de tal modo que en la variable de la situación médica se tendrán en cuenta todas las minusvalías o limitaciones que se acrediten, siendo la puntación total de esta variable la que se obtenga de la suma de los items que la integran. BOJA núm. 196, de 9 de octubre de 2006.

125 Defensor del Pueblo, Informe a las Cortes Generales 2000, BOCG, 8.10.2001, Serie A, núm. 201, p. 135 .

${ }^{126}$ Defensor del Pueblo, Informe a las Cortes Generales 2004, p. 721: "Este sería el caso del baremo que recoge la Orden de 13 de julio de 1998, sobre tramitación de solicitudes y adjudicación de plazas en las residencias de mayores que integran la red publica de la Comunidad de Madrid. Con la aplicación del baremo hoy vigente, la solicitud de un ciudadano de setenta y ocho años que vivía solo, y cuyas limitaciones físicas le impedían continuar en su domicilio, había pasado de 86 puntos, concedidos en un primer momento, a 77 puntos tras ingresar en una residencia privada para recibir la atención que necesitaba debido a su deterioro". 
Más aún, con motivo de algunas quejas formuladas por enfermos alzheimer que no habían alcanzado la edad de 60 años motivo por el cual se les denegó el acceso a una plaza residencial pública, el Defensor del Pueblo de Andalucía ha sugerido que se promueva el desarrollo reglamentario del art. 2.2 de la Ley de Personas Mayores de Andalucía de 1999 en orden a facilitar los beneficios de la misma a los mayores de 55 años, atendiendo entre otros factores al grado de dependencia derivado del alzheimer u otras enfermedades discapacitantes ${ }^{127}$.

\subsubsection{La aplicación de los baremos}

Con independencia del carácter más o menos acertado o arbitrario de los factores del baremo y de su cuantificación, se plantea el problema de su aplicación. Aquí puede anotarse la práctica de introducir criterios de valoración, que pueden ser muy razonables, pero que no están incluidos en el baremo ${ }^{128}$. También se ha observado, en relación con la aplicación del baremo sanitario, la ausencia de protocolos internos en la actuación de los técnicos, que ofrezcan mayores garantías a los ciudadanos y mayor coherencia al sistema ${ }^{129}$.

Pero, sobre todo, el principal problema que se da es la insuficiente motivación de las resoluciones de denegación, inadmisión o relegación a lista de espera. En efecto, existe una práctica generalizada según la cual únicamente se comunica que el expediente no alcanza la puntuación necesaria, o se indi-

127 Defensor del Pueblo de Andalucía, Informe al Parlamento de Andalucía, 2004, pp. 863 y 870. Las primeras Leyes autonómicas reservaron estos servicios a las personas mayores de 65 años, pensionistas mayores de 60 años, y pensionistas mayores de 50 años con incapacidad física o psíquica (Ley de Asturias 7/1991 -art. 3.1-; Ley de Extremadura 2/1994 -art. 1.2-). Por su parte, la Ley de Canarias 3/1996 unificó las dos primeras categorías, al referirse de modo genérico a personas mayores de 60 años. En cambio, la Ley de Andalucía 6/1999 -art. 2- optó simplemente por suprimir el segundo puesto (el de los pensionistas mayores de 60 años), y elevó la posibilidad de extender los beneficios a los mayores de 55 años, criterio seguido parcialmente por la Ley de Castilla y León 5/2003 -art. 2-.

128 Así la Cámara de Cuentas de Andalucía ha detectado la práctica de determinados informes sociales de incluir el concepto de "claudicación o agotamiento" de los familiares con los que convive el solicitante. O la consideración de situación de precario cuando el solicitante está siendo atendido por familiares que no tienen la obligación legal de hacerlo. Informe de Fiscalización de residencias de mayores concertadas con el IASS, correspondiente al ejercicio 2002.

129 Defensora del Pueblo de Navarra, Informe especial al Parlamento de Navarra "La atención a la dependencia de las personas mayores en Navarra”, marzo de 2005, p. 131. 
can los puntos obtenidos sin explicitar los necesarios o bien simplemente se comunica la imposibilidad momentánea de satisfacer su pretensión ${ }^{130}$. Frente, a ello debe postularse la transparencia en el proceso de valoración, de modo que la motivación de la resolución debe contener la puntuación total obtenida conforme a la valoración efectuada, especificándose, en todo caso, los puntos obtenidos por cada uno de los factores objeto de valoración, así como debe informarse sobre la puntuación mínima precisa u obtenida por las últimas personas incorporadas a la prestación de que se trate, a fin de que los interesados puedan conocer sus posibilidades de acceder a la prestación en cuestión, así como, en caso de disconformidad con la puntuación adjudicada, de alegar lo que consideren conveniente en defensa de sus intereses ${ }^{131}$.

Y a los razonamientos estrictamente jurídicos se sobrepone una realidad innegable: los solicitantes de este tipo de prestaciones son personas que en mayor o menor medida se encuentran aquejados de una serie de dolencias, discapacidades físicas, dificultades sociales... que dificultan su capacidad de desenvolvimiento en las tareas diarias, razón por la cual la Administración debe extremar sus medidas a fin de intentar allanar en lo posible las dificultades que puedan surgir en la gestión de las relaciones entabladas por aquéllos ${ }^{132}$.

Por todo ello, hay que entender que la propia escasez de los recursos públicos impone que la transparencia presida el proceso de valoración, de tal modo que la motivación de la resolución debe contener la puntuación total obtenida conforme a la valoración efectuada, especificándose, en todo caso, los puntos obtenidos por cada uno de los factores objeto de valoración, así como debe informarse sobre la puntuación mínima precisa u obtenida por las últimas personas incorporadas a la prestación de que se trate ${ }^{133}$.

${ }^{130}$ Informe del Defensor del Pueblo correspondiente a 1994, p. 852; Informe del Defensor del Pueblo correspondiente a 1996, p. 358.

${ }^{131}$ Defensor del Pueblo, Informe correspondiente a 1994, p. 852; Informe correspondiente a 1996, pp. 99 y 358; Defensor del Pueblo Andaluz, Informe al Parlamento de Andalucía 1995.

132 No se trata, sin más, de realizar una excepción a modo de concesión graciable a algunos individuos, sino de conjugar a un tiempo un principio de justicia social con la inmanente vocación de la Administración de servicio a los ciudadanos. Defensor del Pueblo Andaluz, Informe al Parlamento de Andalucía 1995.

133 Defensor del Pueblo, Informe a las Cortes Generales 1994, p. 852; Informe a las Cortes Generales 1996, pp. 99 y 358; Informe a las Cortes Generales 2003, p. 799. 
En estos casos, el margen de actuación de los comisionados parlamentarios es muy limitado. Así el Defensor del Pueblo del Estado viene reiterando la imposibilidad de intervenir al objeto de que sea adjudicada una plaza a un solicitante determinado, ya que, al producirse los ingresos por el orden de puntuación derivado de los baremos aplicables, cualquier intervención podría ir en contra del mejor derecho de terceras personas ${ }^{134}$. Por ello, la actuación de la institución se dirige fundamentalmente a obtener par los interesados una respuesta expresa en la que se deje constancia de la puntuación obtenida, y a que se facilite, en su caso, información sobre las expectativas reales de ingreso, a fin de dotar al proceso de la máxima transparencia ${ }^{135}$. Así, el Defensor del Pueblo del Estado viene insistiendo en el deber de la Administración de dictar resolución expresa en todos los procedimientos que se inicien, así como de notificarla ${ }^{136}$.

Asimismo, en aras de la indicada transparencia, son interesantes algunas disposiciones autonómicas en las que se obliga a que, en los diez primeros días de cada mes, se exponga en los tablones de la Consejería la relación de plazas adjudicadas el mes anterior, con expresa indicación de la puntuación y de las residencias en que se hayan producido ingresos ${ }^{137}$. Y, en este sentido, se ha defendido la necesidad de que la Administración mantenga, de oficio, periódicamente informados a los interesados sobre el estado de tramitación de sus peticiones, y de las posibilidades de ver satisfechas sus pretensiones ${ }^{138}$.

${ }^{134}$ Defensor del Pueblo, Informe a las Cortes Generales 1994, pp. 850 y ss. y 926; Defensor del Pueblo Informe a las Cortes Generales 1995, pp. 317-318; Informe a las Cortes Generales 2004, p. 721.

135 Defensor del Pueblo, Informe a las Cortes Generales 1999, p. 767; Defensor del Pueblo, Informe a Cortes Generales, 2000, BOCG, 8.10.2001, Serie A, núm. 201, p. 134; Informe a las Cortes Generales 2003, p. 799.

${ }^{136}$ Defensor del Pueblo, Informe a las Cortes Generales 1999, p. 768.

137 Orden 1377/1998, de 13 de julio, sobre tramitación de solicitudes y adjudicación de plazas en las residencias de mayores que integran la red pública de la Comunidad de Madrid. No obstante, tras una actuación del Defensor del Pueblo, la propia Consejería admitió que no se están exponiendo las relaciones, de manera sistemática, si bien dicha información "se ha proporcionado a los interesados cuando así lo han solicitado" (Informe a las Cortes Generales 2006, p. 719).

${ }^{138}$ Defensor del Pueblo, Informe a las Cortes Generales 1994, p. 854, donde se plantea la conveniencia de implantar un sistema de información periódica a los solicitantes de plazas. 


\subsubsection{El caso especial de los ingresos de urgencia social}

En general, los sistemas autonómicos contemplan la atención en situaciones de urgencia ${ }^{139}$. En Andalucía, según el art. 15 del Decreto 28/1990, de 6 de febrero, sobre ingresos y traslados a residencias de tercera edad: «Previa resolución del Director Gerente del Instituto Andaluz de Servicios Sociales, los casos de urgencia social por extrema necesidad, debidamente acreditada, serán ingresadas en los Centros que corresponda inmediatamente, aunque no figuran en las listas de reserva de plazas». Sin embargo, a mediados de la década de los 90, el Defensor del Pueblo Andaluz llegó a declarar que el sistema de servicios sociales en materia de protección al anciano técnicamente ha quebrado: "Hasta tal punto esto es así, que la Administración no dispone de capacidad siquiera para atender la demanda de "ingresos de urgencia social por extrema necesidad", que viene referida a ancianos abandonados, desvalidos y carentes de apoyo familiar" 140 .

Y aunque desde entonces la situación ha mejorado notablemente todavía se producen casos de Resoluciones de Ingreso Urgente de discapacitados y mayores con graves y continuos trastornos de conducta sin que tal medida suponga su ejecutoriedad inmediata, o al menos en un breve espacio de tiempo, sino que más bien al contrario, se prolongan en un tiempo excesivo teniendo en cuenta la urgencia que motiva dichas resoluciones ${ }^{141}$. Así, en relación con el año 2004, según la Administración autonómica, los tiempos medios de espera fueron los siguientes ${ }^{142}$ :

${ }^{139}$ Así, la Ley de Castilla y León 5/2003 establece que cuando la persona mayor se encuentre en situación de urgencia en la que pueda existir riesgo para su integridad, las Administraciones dispondrán los mecanismos adecuados que permitan dar respuesta inmediata a la misma con carácter provisional -art. 34-. Partidario también de plazas de emergencia para la atención inmediata de situaciones de asistencia urgente se expresó el Defensor del Pueblo de Castilla-La Mancha, "Personas mayores desatendidas: una realidad", 2005.

${ }^{140}$ Defensor del Pueblo Andaluz, Informe al Parlamento de Andalucía 1997, p. 785.

${ }^{141}$ Defensor del Pueblo Andaluz, Informe al Parlamento de Andalucía 2005, p. 729. "No se alcanza a comprender como todo el esfuerzo de calidad se centra por la Administración en tramitar con la máxima celeridad el expediente administrativo de ingreso residencial para luego, una vez dictada la correspondiente resolución (que no olvidemos declara de urgencia social el ingreso) abandonarse en dilaciones y demoras sin fin a la hora de llevarlas a efecto, que durante este lapso de tiempo suponen de hecho el abandono y desasistencia del afectado/a" (pág. 732).

142 Defensor del Pueblo Andaluz, Informe al Parlamento de Andalucía 2005, p. 730. 


\begin{tabular}{|ll|}
\hline $0-1$ mes & $20,54 \%$ \\
\hline $1-2$ meses & $36,21 \%$ \\
\hline $2-3$ meses & $18,37 \%$ \\
\hline $3-4$ meses & $10,63 \%$ \\
\hline+4 meses & $14,23 \%$ \\
\hline
\end{tabular}

Fuente: Cámara de Cuentas de Andalucía

A este respecto, debe señalarse que el Decreto 23/2004, de 3 de Febrero, sobre protección jurídica de las personas mayores dispone que "cuando la atención requerida por la persona mayor (por causa de desasistencia o maltrato) no admita demora, la concesión de los servicios de atención domiciliaria o de ingreso en un Centro residencial se efectuará en el plazo máximo de diez días" -art. 9-.

Pero, sobre todo, lo más notable de esta práctica consiste en el uso excesivo de ingreso por el procedimiento de urgencia social. Según los datos de la propia Administración, en el 2004 el número de resoluciones para ingreso por el procedimiento de urgencia social fue de 1125 sobre un total de menos de 9.000 plazas entre propias y concertadas para válidos y asistidos en Andalucía. Como declaró el Defensor del Pueblo Andaluz, esta situación "conduce a la práctica inviabilidad del acceso ordinario por vía de baremo incluso para aquellas personas mayores que obtienen altas puntuaciones en las listas de reserva, tal y como esta Institución viene constatando en las múltiples quejas que por este motivo se nos presentan" ${ }^{143}$.

\subsubsection{Los problemas de movilidad en el conjunto del territorio español}

La fragmentación formal de los servicios sociales en diecisiete sistemas autónomos y aparentemente estancos, ha determinado un problema adicional cuando -como es cada vez más frecuente- los ciudadanos afectados desean acceder a un centro situado en una Comunidad Autónoma diferente de su residencia, principalmente por razones familiares, sobre todo para estar cerca de sus hijos. Además, en caso de varios hijos, es frecuente, el deseo de repartir su tiempo residiendo con cada uno de ellos en distintos períodos del año. Así,

143 Defensor del Pueblo Andaluz, Informe al Parlamento de Andalucía 2005, p. 732. 
desde el año 1997, a partir de las transferencias de las funciones y servicios del antiguo Instituto Nacional de Servicios Sociales a las comunidades autónomas, el Defensor del Pueblo ha venido recibiendo un considerable número de quejas de ciudadanos que, necesitando ingresar en una residencia de tercera edad, encuentran graves dificultades para, en unos casos, retornar a la Comunidad autónoma de la que son originarios y, en otros, acceder a centros próximos a las localidades de residencia de sus familiares más allegados ${ }^{144}$.

En estos casos, el Defensor del Pueblo estatal ha puesto de manifiesto las dificultades para acceder a una residencia se incrementan, pues en las disposiciones sobre la materia de gran parte de las Comunidades Autónomas se contempla, como requisito para acceder a estos servicios, el acreditar un perí-

${ }^{144}$ Defensor del Pueblo, Informe a las Cortes Generales 2002, p. 376. Así, en el Informe a las Cortes Generales correspondiente al año 2005, señalaba el Defensor del Pueblo lo siguiente: "Por otra parte, siguen siendo significativas las solicitudes de traslado a centros de tercera edad, de distinta Comunidad autónoma a la de residencia habitual del solicitante. En este sentido, un ciudadano exponía que, en el año 1992, solicitó al entonces Instituto Nacional de Servicios Sociales una plaza en residencia asistida para su mujer, con una minusvalía del 90 por 100 . Al no existir en ese momento plazas libres en la Comunidad de Madrid, se le concedió plaza en Torremolinos (Málaga), de carácter temporal, hasta que hubiera plaza en esta Comunidad. Desde entonces la mujer del reclamante ha pasado por diversas residencias, procurando su acercamiento a Madrid, lugar donde reside toda su familia, incluido su marido. En el informe remitido por la Consejería de Familia y Asuntos Sociales, se hace referencia al marco jurídico vigente, subrayando que toda las comunidades autónomas carecen de previsión, en sus distintas reglamentaciones de ingreso en los centros, acerca de las posibilidades de traslado o permutas interautonómicas. Subraya, además, las dificultades de articulación de esa posibilidad, teórica y práctica, dadas las diferencias existentes en cuanto a requisitos y criterio de acceso, precios públicos, tipología de centros, etcétera" (Informe a las Cortes Generales 2005, p. 504). No menos significativo era el caso consignado en el Informe anterior: "A pesar del tiempo transcurrido desde la efectividad de las transferencias, se constata que el problema expuesto sigue sin respuesta adecuada, dando lugar a situaciones como la planteada, ante esta Institución, por un residente en Alcalá de Henares, en cuyo escrito sustancialmente exponía que su madre, de noventa y dos años, ocupa plaza en una residencia pública de Segovia, desde el 8 de enero de 1998, solicitando, el 15 de diciembre de 2003, su posible traslado a una residencia de Alcalá de Henares, por ser la localidad donde residen dos de sus tres hijos que se ocupan y mantienen una relación continua con ella. A la solicitud del interesado se respondió desde la Consejería de Familia y Asuntos Sociales de la Comunidad de Madrid, informando de la imposibilidad de realizar el traslado, ya que los únicos que se llevan a cabo son los que tienen lugar entre los centros que forman parte de la red pública de dicha Comunidad. Señalaba asimismo que, cuando la madre ingresó en la residencia de Segovia, en 1998, le era de aplicación la normativa vigente de la Comunidad Autónoma de Castilla y León, que no contempla la posibilidad de traslado a la Comunidad de Madrid" (Informe a las Cortes Generales 2004, p.723). 
odo previo de residencia en el respectivo territorio ${ }^{145}$. Al parecer, en febrero de 2000, la comisión de prioridades del Plan Gerontológico trató esta cuestión, sin que se obtuviera una respuesta favorable de las Comunidades Autónomas, que intentan resolver cada caso de forma individualizada, mediante permutas y acuerdos de financiación, así como contemplando la posibilidad de exención del requisito en supuestos concretos como el reagrupamiento familiar $^{146}$. Frente a ello, se ha sugerido la búsqueda de soluciones generales, que permitan la supresión del requisito de la residencia previa ${ }^{147}$.

\subsection{La ausencia de un derecho subjetivo garantizado a una plaza residencial pública}

Aun cuando las Leyes autonómicas de servicios sociales suelen declarar de modo enfático la superación definitiva de la graciabilidad inherente a las etapas previas de Beneficencia y asistencia social, y reconocer derechos subjetivos a los ciudadanos como contrapartida al carácter público de los sistemas de servicios sociales -caso de la exposición de motivos de la Ley de Aragón-, el hecho es que la generalidad de las Leyes autonómicas -con alguna excepción re-

145 Así, por ejemplo, la Ley de Asturias 7/1991, de 5 de abril, de asistencia y protección al anciano, establece que las personas ancianas deberán, con carácter general y salvo supuestos excepcionales, residir en la Comunidad desde al menos dos años anteriores a la presentación de la solicitud de ingreso -art. 3.2-. De modo similar, la Ley de Extremadura 2/1994-art. 15.1-, que únicamente exceptúa del cumplimiento del requisito de residencia previa a aquellos que les sea de aplicación la Ley de Extremeñidad. Por su parte, el Defensor del Pueblo, en el Informe a las Cortes Generales correspondiente al año 2003, dejaba constancia de la denegación de una solicitud de ingreso en residencia en la Comunidad Valenciana, porque la interesada había cambiado recientemente de domicilio. Debido a este cambio, carecía de derecho en la Comunidad autónoma de procedencia, por no estar domiciliada en ella y, no se admitía su solicitud en su nuevo domicilio por falta de antigüedad (0313478).

${ }^{146}$ No sucedió así en el caso que relata el Defensor del Pueblo, Informe a las Cortes Generales 2002, p. 377: "No recibió la misma respuesta favorable la solicitud de otro ciudadano, hijo único y residente en la Comunidad de Madrid, que solicitó la exención del requisito de domicilio por reagrupamiento familiar para sus padres, al impedirle sus recursos económicos y sus obligaciones laborales, el poder desplazarse a visitarlos con cierta frecuencia. En este caso, la Consejería de Servicios Sociales entendió que los solicitantes tenían cubiertas sus necesidades de atención al haber ingresado en una residencia pública de la Junta de Extremadura, lugar de residencia previa de los solicitantes".

${ }^{147}$ Defensor del Pueblo, Informe a las Cortes Generales 2000, BOCG, 8.10.2001, Serie A, núm. 201, pp. 134-135. Igualmente, Informe a las Cortes Generales 2002, p. 377. 
ciente- no contienen reconocimiento de derechos subjetivos plenos, sino que se limitan a contener un reenvío global a la potestad reglamentaria, sin ningún condicionamiento material, lo que constituye una auténtica deslegalización de la posición del ciudadano ante la Administración ${ }^{148}$. Por su parte, las normas reglamentarias en aquellos casos que abordan la cuestión condicionan el acceso al recurso social a una serie de circunstancias de fuerte componente discrecional (prioridades, objetivos, valoraciones...) y, en última instancia, a la existencia de recursos disponibles ${ }^{149}$.

En ese sentido, aunque el Defensor del Pueblo Andaluz ha defendido en ocasiones la vigencia de un derecho a obtener prestaciones sociales -entre ellas centros residenciales sustitutivos del hogar- en supuestos de necesidad, afirmando su carácter individual desde la perspectiva del ciudadano y su naturaleza de servicio público desde la perspectiva de la Administración. Sin embargo, se ha visto obligado a reconocer de inmediato que este derecho quiebra si en definitiva la Administración carece de los recursos para hacerlo efectivo $^{150}$. De hecho, la propia institución parece rectificar la opinión anterior:

"ni en la legislación estatal ni en la andaluza de servicios sociales se ha introducido como derecho subjetivo no ya el derecho a obtener en un plazo determinado plaza residencial sino ni siquiera a establecer un catálogo de derechos sociales básicos (que no cabe atribuir a las prestaciones sociales básicas de los Servicios Sociales Comunitarios), y ello a pesar de que existe una antigua y extendida aspiración social sobre la necesidad de que exista una Carta de Derechos de contenido social, donde se defina el catálogo de derechos que deban considerarse esenciales por el legislador para garantizar su ejercicio a toda la ciudadanía.

148 Por ello la doctrina (BELTRÁN AGUIRRE, op. cit., pág. 334) señala que las declaraciones que incorporan las Leyes sobre titularidad de derechos tienen un gran componente retórico y muy escasa eficacia jurídica para posibilitar la exigencia del ciudadano frente a la Administración. Muy crítico con este estado de cosas, D. CASADO ("Notas sobre el futuro de los servicios sociales: nuevas necesidades, actividades y garantías", Documentación Administrativa, núm. 217-2722, 2005, p. 189), ha señalado la contradicción del intenso celo competencial de las Comunidades Autónomas en materia de servicios sociales con su tibieza y aun negligencia para garantizar el acceso a los mismos a los ciudadanos.

149 Vid. T. FONT i LLOVET, "Los derechos de los usuarios en los servicios sociales de atención a la tercera edad", Los servicios sociales de atención a la tercera edad. El caso de Cataluña, Tirant lo Blanch, 2002, p. 337 y ss.; J. TORNOS MAS, "Efectividad de los derechos y exigibilidad de los servicios sociales", Documentación Administrativa, núm. 271, 2005, pp. 374 y ss., donde habla de un "derecho debilitado".

${ }^{150}$ Defensor del Pueblo Andaluz, Informe al Parlamento de Andalucía 1999, p. 807. 
Desde esta Institución y en el ejercicio de sus funciones garantistas, se ha venido reiterando la necesidad de pasar de las formulaciones teóricas de derechos a realidades prácticas que sustenten la materialidad y accesibilidad de los ciudadanos a su contenido esencial.

En Andalucía con un criterio plausible, se ha impulsado una importante actividad legislativa de desarrollo de muchos derechos de contenido social, generando expectativas que luego no se corresponden con su efectividad, bien por falta de desarrollo reglamentario o, incluso habiéndose producido éste, por insuficiencia presupuestaria para afrontarlos"151.

A lo sumo podrá hablarse de un derecho subjetivo tras la resolución de adjudicación de la plaza, pero no con carácter previo a la misma ${ }^{152}$.

La situación contrasta con el tratamiento que se otorga por la Administración Sanitaria respecto a otro derecho de contenido social como es el derecho a la Salud, que se ha materializado a través del establecimiento de garantías del mismo en distintos aspectos relacionados con actuaciones clínicas. Así en los casos de primeras consultas de especialista, procedimientos diagnósticos o a intervenciones quirúrgicas se establecen unos tiempos máximos de espera con garantías de que en caso de no obtener una respuesta por el Sistema Sanitario Público de Andalucía podrá el interesado acudir a la iniciativa privada con derecho a ser resarcido en los gastos que se le ocasione hasta el límite señalada reglamentariamente ${ }^{153}$.

Y este es precisamente el camino que han iniciado las leyes autonómicas sobre servicios sociales más recientes, mediante la definición de una cartera de servicios o catálogo de prestaciones, y al que deberá incorporarse la legislación andaluza $^{154}$.

${ }^{151}$ Defensor del Pueblo Andaluz, Informe al Parlamento de Andalucía 2005, p. 733.

${ }^{152}$ En este sentido, J.M. ALONSO SECO, "El 'status' jurídico-administrativo del interno en centros de la red pública asistencial: derechos y obligaciones”, Documentación Administrativa, núm. 271, 2005, p. 421.

${ }^{153}$ Decretos 209/2001 de 18 de Septiembre y 96/2004, de 9 de Marzo, dictados en desarrollo del derecho de acceso a las prestaciones sanitarias en un tiempo máximo del art. 6.1.m) de la Ley de Salud de Andalucía de 1998.

${ }^{154}$ La pionera en este cambio en la posición jurídica del ciudadano ante la prestación de los servicios sociales fue la Ley de Asturias 1/2003, de 24 de febrero, de servicios sociales, la cual prevé la aprobación por Decreto de un catálogo de prestaciones el cual deberá diferenciar las pres- 


\section{LA RESPONSABILIDAD SANCIONADORA EN MATERIA DE RE- SIDENCIAS PARA PERSONAS MAYORES}

\subsection{La inspección administrativa de residencias para personas mayores}

Para la garantía del cumplimiento de la legalidad en materia de centros residenciales para personas mayores, como de cualquier otro centro o servicio social es fundamental el ejercicio por parte de la Administración competente para ello de la potestad sancionadora. Así, ya en 1990 el Defensor del Pueblo exhortó a las Administraciones Públicas competentes a ejecutar programas de inspecciones de las residencias privadas de la tercera edad, al objeto de garantizar que la atención a los residentes se desarrolle en un marco acorde con la dignidad humana y acomodado a las condiciones mínimas materiales y funcionales que se establezcan, así como para asegurar el respeto de los derechos de los usuarios ${ }^{155}$.

Más aún, si el ejercicio de la función inspectora es necesario en cualquier sector, en el ámbito de los servicios sociales y, en particular, de las residencias para personas mayores es fundamental. Las denuncias o quejas de los usuarios son escasas debido a la extrema fragilidad del colectivo, que encuentra serias dificultades físicas, culturales y sociales para defender sus derechos y denunciar los casos de abusos y lesión sobre su persona o sus bienes ${ }^{156}$.

taciones fundamentales que serán exigibles como derecho subjetivo, con independencia, en todo caso, de la situación económica de los beneficiarios -art. 20-. Y, en esta línea, la Ley Foral de Navarra 15/2006, de 14 de diciembre, de servicios sociales, establece que la cartera del sistema público de servicios sociales diferenciará las prestaciones garantizadas, aquellas que son exigibles como derecho subjetivo, de las no garantizadas cuyo acceso será en función de la disponibilidad presupuestaria -art. 19-. Y también en esta línea se sitúa la Ley de Cantabria 2/2007, de 27 de marzo, de Derechos y Servicios Sociales -art. 26-, y la Ley de Cataluna 12/2007, de 11 de octubre, de Servicios Sociales -art. 24.4-. Sin embargo, transcurridos ya algunos años, sobre todo en el caso de Asturias, aún siguen sin aprobarse los Decretos definidores de las carteras de servicios.

155 También la Resolución sobre las ayudas a ancianos en la Comunidad Europea de 1986, aprobada por el Parlamento Europeo, instó a los Estados miembros a revisar de forma periódica las instituciones y hogares de ancianos. Asimismo, el Senado en su informe de 1989 sobre la situación de las residencias para la tercera edad en España -DOCG, Senado, serie I, 22.6.1989, no . 326-, ya había manifestado que la comercialización para el lucro de las residencias privadas, los problemas familiares y sociales forman un conjunto de condiciones para la explotación estos establecimientos por parte de desaprensivos.

156 Defensor del Pueblo Andaluz, Informe al Parlamento de Andalucía 1995, p. 914. En este sentido, el Defensor del Pueblo, Informe a las Cortes Generales 2001, p. 363, dirá: "El notable y progre- 
En general, la función de inspección de las entidades, centros y servicios sociales es competencia reservada en exclusiva a la Administración autonómi$\mathrm{ca}^{157}$. Las únicas modulaciones previstas a esta regla general, son de dos tipos. De un lado, en alguna Comunidad Autónoma se prevé la posibilidad de encomendar a la Administración Local la gestión de las actuaciones propias de la inspección, mediante convenio que deberá establecer la compensación económica que corresponda ${ }^{158}$. Y, de otro lado, en las leyes más recientes se contempla la posibilidad de que la verificación del cumplimiento por parte de los centros y servicios de las condiciones materiales y de accesibilidad pueda ser llevada a cabo, no ya directamente por el personal de inspección de la Administración, sino por entidades o profesionales acreditadas ${ }^{159}$.

Y, en todo caso, es claro que esta función inspectora no debe ceñirse a los centros inscritos o autorizados en el correspondiente registro, es decir, a los centros "legales", sino que, con mayor razón, debe incluir a los centros "ilegales”, en los que cabe presumir que mayor riesgo de conculcación de los derechos de los usuarios, precisamente por la ausencia del control preventivo de la Administración.

sivo incremento de la demanda de atención lleva, sin duda, aparejada la creación y puesta en funcionamiento de servicios de diversa índole, que pretenden dar respuesta a las necesidades de la población mayor y de sus familias. Por ello, resulta especialmente necesario el control que las administraciones públicas deben establecer, al objeto de garantizar los derechos de aquellos ciudadanos que acuden a la iniciativa privada para dar respuesta a sus necesidades de atención residencial. Debido a sus condiciones de dependencia estas personas se encuentran en un grado de mayor indefensión, por lo que deben ser objeto de una atención especial sobre las condiciones de seguridad, comodidad e higiene necesarias para el desarrollo de su vida cotidiana".

${ }^{157}$ Entre las Leyes generales de servicios sociales, Ley de Cantabria 5/1992 -art. 41-; Ley de Galicia 4/1993 -arts. 26.3 y 70-; Ley de la Comunidad Valenciana 5/1997 -art. 69.1-. Y la totalidad de las Leyes sobre régimen disciplinario del sector: Ley de la Comunidad de Madrid 8/1990 -art. 5-; Ley Foral de Navarra 9/1990 -art. 5-; Ley de Cataluña 16/1996 -art. 5-; Ley de La Rioja 5/1998 -art. 11.1-. La excepción es la Ley del País Vasco 5/1996 -art. 11- la cual atribuye esta función inspectora a las Diputaciones Forales.

${ }^{158}$ Ley de Cataluña 16/1996 -art. 4.1-; Ley de las Islas Baleares 4/1999 -art. 6-, en relación con los consejos insulares y los municipios de más de 20.000 habitantes.

${ }^{159}$ Ley de Cataluña 16/1996 -art. 6.2-; Ley de La Rioja 5/1998 -art. 12.2-, las cuales precisan, para salvaguardar la imparcialidad, que dicha verificación en ningún caso puede ser contratada a personas físicas o jurídicas que gestionen cualquier servicio, establecimiento o entidad de servicios sociales, que sean propietarios o que tengan intereses económicos en los mismos. Vid, sobre todas estas cuestiones, S. FERNÁNDEZ RAMOS, La actividad administrativa de inspección, Comares, Granada, 2002. 
Sin embargo, no pareció entenderlo así la Administración autonómica andaluza, la cual únicamente inspeccionaba sus propios centros (dependientes del ya extinto Instituto Andaluz de Servicios Sociales (IASS) y aquellas residencias privadas concertadas o subvencionadas por la Administración, de modo que quedaban excluidas de cualquier tipo de control tanto el resto de las residencias públicas (de Diputaciones y Ayuntamientos) ${ }^{160}$ como las residencias privadas no concertadas, y ello independientemente de que se encontraran autorizadas o no, pues incluso en las autorizadas el control se limitaba a la visita inicial al solicitar la autorización, pese a que las circunstancias han podido varias notablemente con el curso de los años y deteriorarse, reducirse o eliminarse los servicios inicialmente previstos ${ }^{161}$.

"Ni que decir tiene que es la falta de control sobre los centros la que genera el mayor número de irregularidades en este sector, si bien no es exacto, sin embargo, identificar Residencias no autorizadas con Residencias sin control alguno, porque también existen otras autorizadas sobre las que no se ejerce, de hecho, ningún tipo de supervisión. Es frecuente que haya Residencias a las que sólo se les ha girado una visita, en el momento de su apertura, sin que con posterioridad hayan sido sometidas a ninguna inspección, pese a que sus circunstancias han podido variar notablemente con el curso de los años y deteriorarse, reducirse o eliminarse los servicios inicialmente previstos. Esta ausencia de control alcanza su punto álgido, lógicamente, en las Residencias que carecen de autorización administrativa, y ello posibilita que en las mismas puedan originarse las más variadas formas de vulneración de los derechos de los usuarios. La pasividad de la Administración autonómica es el mejor caldo de cultivo posible para el florecimiento de toda una red paralela de residencias, cuyo afán de lucro les lleva no sólo a ignorar la normativa legal, sino a desarrollar prácticas atentatorias contra los derechos de los ancianos y contra su propia dignidad"162.

${ }^{160}$ Las residencias vinculadas con la Administración del Estado o pertenecientes a Diputaciones o Ayuntamientos, desarrollaron sus actividades al margen de la supervisión de la Administración Autonómica, que había delegado "de facto" en dichas Entidades su facultad de inspección.

161 Sin embargo, no lo entendió así el Instituto Andaluz de Servicios Sociales, que se consideró incompetente para inspeccionar los centros de las entidades no inscritas, criterio que fue justamente censurado tanto por el Defensor del Pueblo estatal -Informe a las Cortes Generales 1996, p. 156-, como por Defensor del Pueblo Andaluz - Informe al Parlamento de Andalucía 1995, p. -, que llegó a calificar esta actitud de la Administración de autolimitar su campo de actuación a los Centros legales de negligente.

162 Defensor del Pueblo Andaluz, "Investigación sobre las Residencias de Ancianos Ilegales", Informe al Parlamento de Andalucía 1995, p. 934. 
Sólo después de que Defensor del Pueblo Andaluz recomendase la implantación efectiva de un servicio de Inspección que, a través de planes anuales, asumiera el control periódico de las Residencias autorizadas o concertadas, y desarrollara las labores de investigación precisas para la averiguación de Residencias carentes de autorización ${ }^{163}$, fue aprobado el Decreto 141/1999, de 8 de junio, por el que se regula la inspección de los servicios sociales de la Comunidad Autónoma. Desde entonces se han aprobado varios planes de inspección que han supuesto un impulso notable a esta importante labor de control, en los que el sector de las personas mayores se considera prioritario ${ }^{164}$.

A este respecto, es destacable el acertado criterio contenido en algunas normas autonómicas en virtud de las cuales, a los efectos de asegurar la protección de los derechos de los usuarios, se impone una periodicidad mínima a la inspección de los centros y servicios de los que la inspección tenga constancia ${ }^{165}$. En Andalucía, la Ley 6/1999 no contiene una disposición similar, sino que se limita a ordenar una investigación en caso de denuncias formuladas ante las Administraciones acerca de la desasistencia en que pueda hallarse una persona mayor -art. $43-{ }^{166}$. Por ello, las inspecciones de oficio quedan remitidas a lo dispuesto en los planes de inspección ${ }^{167}$.

${ }^{163}$ Defensor del Pueblo Andaluz, "Investigación sobre las Residencias de Ancianos Ilegales", Informe al Parlamento de Andalucía 1995, p. 940.

${ }^{164}$ Con todo la situación es similar en otras Comunidades Autónomas. Así, la Defensora del Pueblo de Navarra, Informe especial al Parlamento de Navarra "La atención a la dependencia de las personas mayores en Navarra", marzo de 2005, p. 174, ha señalado que a pesar del aumento de la actividad inspectora en los últimos años, "no queda garantizado en Navarra que éstas se hagan de forma sistemática y tampoco que las diferentes residencias y entidades titulares sean tratadas a este respecto por igual. Así mismo, se deriva de esta no regulación una falta de seguridad del bienestar de los usuarios".

${ }^{165}$ Ley de Cataluña 16/1996 -art. 7.2-y Ley de La Rioja 5/1998 -art. 13.2-; Ley de la Comunidad de Madrid 11/2002 -art. 22- obligan a una inspección anual, al menos, a los centros residenciales.

${ }^{166}$ En términos casi idénticos, la Ley de Castilla y León 5/2003 -art. 13-.

${ }^{167}$ Así, debe observarse que durante el ejercicio de 2002, y en relación con las residencias para mayores concertadas, sólo en dos provincias se visitaron, al menos, la mitad de las residencias concertadas (Córdoba y Granada), y en tres provincias se visitaron menos de la cuarta parte de las residencias concertadas: Almería, Málaga y, sobre todo, Sevilla en la que no se cursó visita alguna. Informe de la Cámara de Cuentas de Andalucía sobre residencias concertadas para mayores, correspondiente al ejercicio de 2002. A este respecto, el Plan General de Inspección de las Entidades, Servicios y Centros de Servicios Sociales de la Comunidad Autónoma de Andalucía para el año 2005, aprobado por acuerdo del Consejo de Gobierno, de 18 de enero de 2005, dispuso que dentro del sector de las personas mayores se visitarán todos los centros residenciales. 
En cuanto al modo de proceder en las visitas de inspección, la Ley de Andalucía 6/1999 dispuso que los servicios de inspección velarán por el respeto a la voluntariedad en el ingreso y permanencia en el centro, para lo cual "podrán solicitar del interesado que ratifique la voluntariedad de sus estancia, mediante entrevista personal mantenida sin la presencia de familiares ni de representantes del centro" -art. $45.4{ }^{168}$.

En relación con los centros privados que no conciertan sus plazas con la Administración sino que se limitan a ofrecen sus plazas al mercado, podría diferenciarse entre centros privados autorizados debidamente por la Administración y centros clandestinos, esto es que funcionan sin el título administrativo habilitante para ello, y, por tanto, en situación de ilegalidad, sin perjuicio de la posibilidad de su legalización a posteriori. En relación con ambos tipos de centros la Administración, se podría diferenciar entre una actividad de "comprobación" referida a la verificación del cumplimiento de las prescripciones legales por parte de los centros autorizados, es decir, aquellos que funcionan regularmente, y cuya existencia consta oficialmente a la Administración, y una actividad de "investigación" orientada al descubrimiento y persecución de las actividades clandestinas, es decir que se ejercen desprovistas de la debida autorización ${ }^{169}$.

${ }^{168}$ En desarrollo de este precepto, el Decreto 23/2004, de 3 de febrero, por el que se regula la protección jurídica a las personas mayores, establece en su artículo 10 que la Inspección de Servicios Sociales velará, mediante actuaciones programadas, por el respeto de los derechos de las personas mayores que hayan ingresado en Centros residenciales, "y desarrollará una intervención directa con los mayores residentes sin la presencia de familiares ni de responsables del Centro, al objeto de comprobar la voluntariedad de su estancia, el trato dispensado por los trabajadores, así como el grado de satisfacción o de disconformidad con los servicios recibidos. Si como consecuencia de las entrevistas, se concluyese la imposibilidad de alguna persona mayor de expresar su voluntad, se le exigirá al responsable del Centro que acredite haber adoptado las medidas previstas para los supuestos de incapacitación”. Así, en el Plan General de Inspección de las Entidades, Servicios y Centros de Servicios Sociales de la Comunidad Autónoma de Andalucía para el año 2005, se introdujo, como novedad, el Área de Protección Jurídica a las Personas Mayores, con la previsión de entrevistas personalizadas con las personas que voluntariamente quieran acceder a realizarlas, sin la presencia de familiares, responsables del Centro, ni de otros usuarios compañeros del Centro residencial.

169 Vid. S. FERNÁNDEZ RAMOS, La actividad administrativa de inspección, op. cit., p. 96. 
En este segundo aspecto, es fundamental que los Servicios de Inspección intervengan en caso de denuncia ${ }^{170}$. Pero, además, se plantea la cuestión relativa al tratamiento de las denuncias formuladas por los propios usuarios. A este respecto, el Defensor del Pueblo de Andalucía ha detectado que en ocasiones se puede prejuzgar una denuncia sobre la base de informaciones sobre el estado de salud mental del denunciante:

"Teniendo en consideración que la población que accede a las residencias de mayores cada vez cuenta mayor edad, las demencias y otras alteraciones psíquicas serán más frecuentes, de manera que ante las denuncias formuladas por los usuarios sobre el funcionamiento de los centros, y para la efectiva defensa de sus derechos, será preciso evitar que se prejuzgue lo realmente sucedido, y que por parte de la Inspección de Servicios Sociales se extremen las precauciones en el curso de las investigaciones, y se empleen todos los medios a su alcance para el esclarecimiento de los hechos"171.

\subsection{El régimen sancionador}

En Andalucía, la Ley 2/1988, de 4 de Abril, de Servicios Sociales, estableció un régimen de infracciones y sanciones marcadamente exiguo, y referido exclusivamente a tipos de infracción de carácter formal, como la obstrucción de los servicios de inspección pública -art. 32.2 $\left.2^{\circ} . c\right)$, y, sobre todo, la infracción consistente en «incumplir la normativa sobre Registro de Entidades y Centros de Servicios Sociales» - art. $\left.32.2^{\circ} . a\right)^{172}$.

${ }^{170}$ En el Informe a las Cortes Generales correspondiente al año 2005 se dirá (p. 505): "La adecuada atención a los usuarios de las residencias, es una cuestión que preocupa tanto al Defensor del Pueblo, como a las propias administraciones implicadas. Por ello, entendemos que las quejas y denuncias que formulan los propios residentes o sus familiares deben ser, en todo caso, objeto de verificación por parte de los órganos administrativos que tienen encomendada la inspección para garantizar los derechos de las personas mayores, adoptando las medidas que fueran necesarias $(0422348)$.

171 Defensor del Pueblo de Andalucía, Informe al Parlamento de Andalucía, 2005, p. 739. Todo ello sin tener en cuenta que la Ley 41/2002, de 14 de noviembre, no ampara el acceso a la información sobre el estado de salud de un paciente por parte de la inspección de servicios sociales.

${ }^{172}$ Es cierto que en el Derecho administrativo sancionador se viene admitiendo que la Ley integre la conducta infractora mediante la remisión a otras normas (SSTC 219/1989, 116/1999, entre otras). Pero en este caso la remisión engloba múltiples supuestos, lo que pone en cuestión la exigencia constitucional de la predeterminación de las conductas ilícita. Ahora bien, como puso de manifiesto el Defensor del Pueblo Andaluz, ese riesgo podría haber sido eliminado si la Administración Autonómica hubiera concretado dicho régimen sancionador a través de la corres- 
Pero, además, la Ley 2/1988 no determinó las autoridades encargadas de instruir el oportuno expediente ni de acordar, en su caso, las sanciones procedentes, sino que se limitó a aludir a «los órganos competentes de la Junta de Andalucía» (artículo 31). Y esta inconcreción de la Ley 2/1988 de servicios sociales en materia sancionadora, en lugar de ser subsanada diligentemente mediante la aprobación de un posterior Decreto de desarrollo de la misma, sirvió de pretexto a la Administración para la inaplicación de su régimen sancionador hasta 1996, ocho años después de la aprobación de la Ley ${ }^{173}$.

De este modo, la inactividad normativa de la Administración desembocó en una autolimitación de su potestad sancionadora, hasta el punto de verse privada de la posibilidad de adoptar medidas correctivas ante flagrantes incumplimientos de la normativa que rige los centros de Servicios Sociales. Tal actitud generó, en lo que a residencias de ancianos se refiere, una consciencia de total impunidad por parte de quienes han infringido la normativa vigente, en cuanto que no se les ha impuesto ninguna sanción, y ello, en definitiva, ha repercutido gravemente en el nivel asistencial recibido por los usuarios, en cuanto que el control de las condiciones sobre la prestación de los servicios y la calidad exigible a los mismos ha sido en muchos casos puramente ficticio ${ }^{174}$.

Como señalara el Defensor del Pueblo Andaluz, esta desidia de la Administración a ejercer su potestad sancionadora no sólo ignora el mandato legal, sino que, sobre todo, olvida que "la concesión de ese poder tiene una finalidad esencial, cual es la protección de los colectivos más desfavorecidos de la

pondiente vía reglamentaria, tal como autoriza el art. 129.3 LRJPAC, pues contaba con la habilitación para ello en la Disposición Final Segunda de la Ley 2/1988, que autoriza al Consejo de Gobierno "para dictar la normativa necesaria para la ejecución y desarrollo de la presente disposición».

173 "La falta de atribución específica de la potestad sancionadora a los órganos correspondientes parece haber llenado de recelo a la Administración, ante posibles actuaciones viciadas de incompetencia", pues -como es sabido- el artículo $127.1^{\circ}$ de la Ley 30/1992, de 26 de Noviembre, de Régimen Jurídico de las Administraciones Públicas y del Procedimiento Administrativo Común, establece: «El ejercicio de la potestad sancionadora corresponde a los órganos administrativos que la tengan expresamente atribuida, por disposición de rango legal o reglamentario, sin que pueda delegarse en órgano distinto".

174 "La renuencia de la Administración Autonómica a desarrollar el régimen sancionador contenido en la Ley de Servicios Sociales, máxime cuando su pasividad, mantenida desde hace ya un lustro, ha ocasionado la derogación fáctica del Título VI de la Ley, como si de una "desuetudo" se tratase". Defensor del Pueblo Andaluz, "Investigación sobre las Residencias de Ancianos Ilegales", Informe al Parlamento de Andalucía 1995, pp. 924-925. 
comunidad, que son, con carácter general, los destinatarios de los Servicios Sociales. De este modo, cuando se castiga una infracción no sólo se pone en marcha una actividad represiva, sino que a la vez se tutelan otros intereses dignos de protección... la dejación de competencias que se viene produciendo no es una cuestión de orden teórico, enmarcada en el ámbito de la organización administrativa y de repercusión meramente interna. En este caso, los perjudicados por esta indolencia administrativa tienen nombres y apellidos, son ancianos a los que se les vulneran sus derechos y que por su situación personal carecen de medios de defensa" 175 .

En cuanto a las infracciones detectadas en la práctica, en Residencias dependientes de Entidades públicas y en Residencias concertadas no se aprecian graves lesiones de los derechos de los usuarios ${ }^{176}$. Las deficiencias en la prestación de servicios a los ancianos detectadas son generalmente de orden menor, como las derivadas de estructuras arquitectónicas que han perdido funcionalidad con el paso del tiempo, o que, en sus inicios, no estaban previstas para que en ellas se desarrollasen prestaciones de carácter asistencial. Así, algunos Centros no se encuentran adaptados plenamente al Decreto de eliminación de barreras, y en otros, predomina aún la concepción de la Residencia como establecimiento hotelero más que como comunidad de asistencia integral al anciano ${ }^{177}$.

Sin embargo, aun sorprende la falta de cumplimento de reglas formales de autorización y acreditación. Así, la Cámara de Cuentas de Andalucía, en un

175 "Precisamente por esta circunstancia, la Administración debe asumir su protección como un objetivo prioritario, utilizando todos los medios que la Ley pone a su alcance, incluido su poder sancionador. Defensor del Pueblo Andaluz", "Investigación sobre las Residencias de Ancianos Ilegales", Informe al Parlamento de Andalucía 1995, pp. 936-937.

${ }^{176}$ La fuente más notoria de conflictos en buena parte de las residencias proviene del hecho de verse obligados a compartir habitaciones comunes sin haber podido elegir al compañero de habitación. Esa fue la conclusión del Valedor do Pobo, en su Informe extraordinario "Situación de los ancianos en Galicia", junio 1994, p. 486, tras un exhaustivo examen de las residencias públicas.

177 "Ahora bien, particular mención merece la falta de programas especiales de atención a residentes con problemas psiquiátricos, que son atendidos en la mayoría de los casos por un personal carente de formación específica, así como la falta de una acción coordinada en este asunto entre los Servicios Sociales y los Servicios Sanitarios". Defensor del Pueblo de Andalucía, Informe al Parlamento de Andalucía 1995, pp. 934. 
informe de fiscalización de las residencias de mayores concertadas con el entonces IASS, correspondiente al ejercicio de 2002 y publicado en el 2005, arrojó el dato de que el 33\% de las residencias estudiadas no disponían ni acreditación y, más sorprendente aún, el 24\% no disponían ni tan siquiera de autorización (funcionaban sobre la base de prórrogas indefinidas). Pero, además, la institución declaró no tener conocimiento de que se hubiera producido resolución expresa alguna del ya extinto IASS sobre incumplimiento de los requisitos señalados, lo que hubiera determinado la imposibilidad de continuar con la actividad concertada ${ }^{178}$.

En todo caso, los atentados más graves a la dignidad y derechos de los usuarios aparecen sobre todo en centros clandestinos o ilegales, en relación con los cuales en los medios de comunicación social son, por desgracia, frecuentes las noticias sobre malos tratos a ancianos agresiones físicas, presiones psicológicas, comportamientos de desatención y desasistencia- en residencias de tercera edad ${ }^{179}$.

"Las vejaciones, las amenazas, las agresiones físicas, la desnutrición, son moneda de cambio demasiado frecuente en algunas Residencias. La falta de medios y de un personal con formación suficiente para dispensar un tratamiento adecuado a los ancianos, en atención a sus limitaciones físicas o psíquicas, da paso a un régimen represivo a través del cual se ejerce el control sobre los residentes. Así, el miedo al castigo o la administración de fármacos de efectos sedantes contribuye a que la tranquilidad impere en estos Centros, eliminando por completo cualquier ten-

${ }^{178}$ Los datos se corresponden a un total de 87 centros concertados con el IASS en las provincias de Cádiz, Córdoba, Jaén y Sevilla. BOJA núm. 108, de 6 de junio de 2005. En el informe también se detalla la situación de centros concertados con acreditación caducada. La situación no es muy diferente en otras Comunidades Autónomas. Así, el Justicia de Aragón, señalaba en su informe especial de 2004: "la gran mayoría (de las residencias) no disponen de la licencia de apertura definitiva y no están inscritos en el registro al efecto. La falta de inscripción en el Registro de entidades, servicios y establecimientos de acción social puede obedecer a diversas razones: la clandestinidad del centro, no teniendo la Administración conocimiento de su existencia; no tener la licencia municipal de apertura; el incumplimiento de algún requisito de tramitación o la necesidad de realizar pequeñas modificaciones estructurales. En ocasiones, la residencia cumple todos los requisitos y se encuentra a la espera de que la inspección de centros realice la visita de comprobación para su concesión” (p. 33).

${ }^{179}$ La relación de vulneraciones que contiene el informe del Defensor del Pueblo Andaluz, Informe al Parlamento de Andalucía 1995, pp. 934 y ss, es estremecedora, inquietante: hacinamiento, pésimas condiciones higiénico-sanitarias, alimentación defectuosa y sin control médico, reclusión de ancianos, expoliación patrimonial... 
tativa de reclamación o de denuncia por parte de los ancianos ante la Dirección de los mismos o las autoridades competentes" ${ }^{180}$.

Es cierto que estas denominadas "Residenciales ilegales" al desarrollar su actividad desde la clandestinidad, es decir, ocultándose a los ojos de la Administración, su detección presenta mayores problemas, pero, desde luego, en modo alguno irresolubles. Piénsese que para la captación de potenciales clientes necesariamente han de contar con una publicidad, al objeto de darse a conocer y ofrecer sus servicios: los folletos, los anuncios en los diarios sirven perfectamente a tal propósito. Quiere ello decir que la Administración, a través de una labor de investigación directa, o mediante la colaboración de otras Entidades públicas, de Organizaciones de Mayores o de Asociaciones de Residencias Autorizadas, puede obtener información al respecto ${ }^{181}$.

Finalmente, debe anotarse que la Ley de Andalucía 6/1999 supuso la introducción, por fin, de un régimen sancionador completo, en el que se tipifican no sólo infracciones formales ${ }^{182}$, sino también infracciones materiales, en las que la lesión o riesgo de la misma de los derechos e intereses de los usuarios es directa ${ }^{183}$.

\subsection{La proliferación de centros clandestinos}

Pero, sobre todo, como pusiera de manifiesto el Defensor del Pueblo Andaluz, una cuota importante de responsabilidad recae sobre la Administración debido a las señaladas lagunas normativas y a la inactividad de los servicios de inspección:

"Es, en definitiva, la falta de control sobre las residencias la que genera el mayor número de irregularidades en este sector". "La pasividad de la Administración autonómica es, pues, el mejor caldo de cultivo posible para el florecimiento de toda una red paralela de residencias, cuyo afán de lucro les lleva no sólo a ignorar la

180 Defensor del Pueblo Andaluz, Informe al Parlamento de Andalucía 1995, p. 64.

181 Defensor del Pueblo Andaluz, Informe al Parlamento de Andalucía 1995, p. 936.

${ }^{182}$ Las infracciones graves contenidas en las letras $l$ ) a $q$ ) del art. 52 y las muy graves contenidas en las letras $c$ ) y d) del art. 53.

${ }^{183}$ Las infracciones graves contenidas en las letras $a$ ) a $k$ ) del art. 52 y las muy graves contenidas en las letras $a$ ) y $b$ ) del art. 53 . 
normativa existente, sino a desarrollar prácticas atentatorias contra los derechos de los ancianos y contra su propia dignidad"184.

Más aún, el Defensor del Pueblo Andaluz puso de manifiesto cómo en los casos de denuncias la Administración autonómica pone en marcha toda una serie de actuaciones impulsora de competencias ajenas, a la vez que mantiene una absoluta pasividad sobre las competencias propias: da traslado de los hechos al Ayuntamiento, por si el centro carece de licencia de apertura, o al Ministerio Fiscal, por si los hechos pueden revestir carácter delictivo. Con estas comunicaciones se intenta suplir el ejercicio de la propia potestad sancionadora, obviando que cuando se castiga una infracción no sólo se pone en marcha una actuación represiva, sino que a la vez se tutelan los derechos e intereses de los ancianos.

Pero de un modo lúcido, el Defensor del Pueblo Andaluz añade la siguiente observación:

"La auténtica razón de fondo que da origen a unas residencias carentes de los servicios necesarios para el cuidado de los ancianos es la insuficiencia de plazas residenciales de que adolecen las estructuras administrativas de Servicios Sociales. El déficit de plazas, materializado en unas ingentes listas de espera, provoca que la demanda se desplace hacia otros sectores, en busca de una solución a corto plazo. Sin embargo, la escasez de recursos económicos de muchos ancianos y de su entorno familiar hace inviable su incorporación a plazas (legales) ofrecidas por empresarios privados (...) Antes esta situación, nunca faltan individuos sin escrúpulos que ofrecen plazas a precios mucho más asequibles, pero que, como contrapartida, no cuentan con los servicios imprescindibles para garantizar la atención de los ancianos. Así, la falta de espacio, el empleo de un personal escaso y poco formado, la existencia de barreras arquitectónicas, etc, no son sino consecuencias de un objetivo común, la reducción de gastos y el aumento de beneficios, que se alcanza a costa del bienestar de los residentes en tales centros. Cuando estas circunstancias se extreman, las residencias se convierten en auténticos aparcamientos humanos", donde se depositan a los ancianos hasta su fallecimiento" 185 .

184 Defensor del Pueblo Andaluz, Informe al Parlamento de Andalucía 1995, p. 934. Asimismo, la institución señalaba que "quienes padecen unas peores condiciones de trato son los ancianos de economías más débiles, que no tienen posibilidad alguna de elegir un Centro en el que se le garanticen unas condiciones mínimas de asistencia, sino que, por el contrario, se ven abocados a ingresar en establecimientos en los que el respeto a la legalidad y a los derechos de los usuarios quedan marginados por completo.

185 Defensor del Pueblo Andaluz, Informe al Parlamento de Andalucía 1995, p. 937. 
"Ahora bien, la escasez de plazas residenciales que la Administración gestiona, bien directamente o mediante conciertos, no sólo potencia la aparición de residencias ilegales, sino que al mismo tiempo dificulta su erradicación... cuando la Administración constata graves irregularidades en una residencia, tendría que proceder a su clausura, mas qué hacer con los ancianos ocupantes de la misma, si los establecimientos de que dispone están saturados... Desde esta perspectiva, el funcionamiento de un Servicio de Inspección y la utilización del régimen sancionador ayudarían a configurar la auténtica dimensión de la necesidad de plazas residenciales en la Comunidad" 186 .

Tras este inquietante Informe del Defensor del Pueblo Andaluz, la Administración autonómica dio varios pasos en orden a corregir los aspectos normativos y organizativos defectuosos -Orden de 29 de febrero de 1996 de condiciones materiales y funcionales de los centros y Decreto de 8 de junio de 1999 de la Inspección de Servicios Sociales, ya reseñados-, sin embargo no es claro que hayan cambiado totalmente los modos de operar.

De ello es expresivo el asunto que motivó la queja al DPA 99/3776 sobre una residencia clandestina en la propia Sevilla: unos particulares denunciaron al Ayuntamiento de Sevilla y a la Administración autonómica en 1997 el funcionamiento desde 1996 de una residencia de ancianos sin licencia municipal ni autorización autonómica $^{187}$. Pues bien la actuación de ambas Administraciones no pudo ser más desconcertante. El Ayuntamiento, si bien en un primer momento ordenó la clausura del establecimiento, no sólo no llegó a ejecutar dicho cierre, sino que otorgó en 1998 una licencia de apertura incondicionada como residencia de ancianos, a pesar que desde la J.A. no se había concedido autorización alguna. Pero la actuación de la Administración no fue a la zaga, pues tras constatar que, en efecto, el establecimiento no reúne los requisitos establecidos en la normativa para las residencias de ancianos, admite que siga funcionando como vivienda tutelada, pero sin imponer condición alguna de acuerdo con la normativa ni conceder efectivamente dicha autorización (el expediente por cambio de tipología del centro había caducado). Por último, a los dos años de la primera denuncia y sólo tras insistentes reclamaciones, la Administración inició un procedimiento sancionador, pero tipificando los hechos, en lugar de infracción muy grave por actividad clandestina, como mera infracción leve por el uso de la condición de centro o entidad acreditada sin estarlo ${ }^{188}$.

\footnotetext{
186 Defensor del Pueblo Andaluz, Informe al Parlamento de Andalucía 1995, p. 938.

187 Defensor del Pueblo Andaluz, Informe al Parlamento de Andalucía 1999, pp. 828 y ss.

188 Defensor del Pueblo Andaluz, Informe al Parlamento de Andalucía 2000, pp. 828 y ss.
} 
Con este proceder, como señaló acertadamente el Defensor del Pueblo Andaluz, la Administración, que dispone de medios punitivos con que disuadir actuaciones irregulares, queda inerme ante cualquier empresa que decidiera instalar sin permisos una residencia de ancianos. Este tipo de actuaciones producen el efecto perverso de incentivar el incumplimiento de la normativa reguladora de los centros de servicios sociales. En términos estrictamente económicos pudiera resultar rentable iniciar clandestinamente la actividad de una residencia de ancianos pues a lo sumo supondría un coste menor, muy inferior al que supone cumplir la normativa y que, a la postre, se repercutiría sobre los usuarios ${ }^{189}$. En definitiva, cuando la Administración detecta, más obligada por terceros que de oficio, un vulneración de legalidad, parece más preocupada en adaptar la normativa a la situación irregular, que en que se adapte el centro a la normativa.

\section{LAS RESIDENCIAS PARA PERSONAS MAYORES EN EL NUEVO SISTEMA DE ATENCIÓN A LA DEPENDENCIA}

\subsection{Aspectos generales del Sistema para la Autonomía y Atención de la De- pendencia}

Ante las enormes dimensiones que venía alcanzado el problema social de la dependencia, debido en parte a los acelerados cambios demográficos y en parte a las propias insuficiencias de los sistemas de servicios sociales de las Comunidades Autónomas, el Estado ha decidido intervenir de forma decidida creando el ya célebre Sistema para la Autonomía y Atención de la Dependencia (SAAD), como una nueva modalidad de protección social, creado mediante la Ley 39/2006, de 14 de noviembre, de Promoción de la Autonomía Personal y Atención a las personas en situación de dependencia ${ }^{190}$.

Como se recordará, el artículo 50 de la Constitución contenía dos mandatos dirigidos a los poderes públicos. De un lado, un sistema de pensiones que garantizara la suficiencia económica de las personas mayores, objetivo sobre el que ha actuado el Sistema de Seguridad Social en las últimas décadas.

\footnotetext{
189 Defensor del Pueblo Andaluz, Informe al Parlamento de Andalucía 2000, pp. 832.

${ }^{190}$ Esta Ley vino precedida por múltiples estudios e informes, entre los que destaca el Libro Blanco de Atención a las personas en situación de dependencia en España, Ministerio de Trabajo y Asuntos Sociales, 2004.
} 
Pero, de otro lado, la Constitución obligó a los poderes públicos a promover el bienestar de los mayores mediante un "sistema de servicios sociales". Ahora bien, dado que los servicios sociales son, en principio, de competencia exclusiva de las Comunidades Autónomas, el Estado ha tenido que acudir a un título competencial genérico, aquel que reserva al Estado la competencia para la regulación de las condiciones básicas que garanticen la igualdad de todos los españoles en el ejercicio de los derechos y en el cumplimiento de los deberes constitucionales (artículo 149.1CE) ${ }^{191}$.

El SAAD comprende dos tipos de prestaciones de atención a la dependencia: de un lado, los servicios del Catálogo, que tienen carácter prioritario -art. 14.2-, y, de otro lado, las prestaciones económicas vinculadas al servicio, que tienen un marcado carácter subsidiario -art. 17.1-. Asimismo, en lo que nos interesa aquí, el Catálogo de servicios incluye, entre otros, el Servicio de Atención Residencial de personas mayores en situación de dependencia -art. 15.1-. Y este servicio, como el resto de los servicios del Catálogo, se prestará a través de la oferta pública de la Red de Servicios Sociales de las respectivas Comunidades Autónomas -arts. 3.o), 14.2 y 16.1-. Asimismo, de acuerdo con el Real Decreto 727/2007, de 8 de junio, el servicio de atención residencial se prevé tanto para la dependencia en grado III (gran dependencia) como en grado II (dependencia severa) -art. 2- ${ }^{192}$.

Las principales aportaciones del SAAD en relación con los sistemas autonómicos de servicios sociales son las siguientes:

${ }^{191}$ Previamente, la comisión para el estudio del problema de la dependencia creada por el Gobierno en octubre de 2003, había señalado que la descentralización de las competencias sobre servicios sociales "produce un incremento de los niveles totales de gasto, aunque una gran dispersión en los niveles de intensidad y calidad relativos".

${ }^{192}$ La normativa de desarrollo de la Ley determina la intensidad de protección de cada uno de los servicios previstos en el catálogo de servicios en función del grado y nivel de dependencia, de tal modo que la Administración debe limitarse a asignar los servicios (o prestaciones) que corresponden al solicitante según su grado y nivel de dependencia -art. 28.3-. No obstante, sucede que el Real Decreto 727/2007, de 8 de junio, establece un abanico muy amplio para cada grado, con una elevada coincidencia, de tal modo que las Administraciones podrán actuar -y probablemente no cabe otra solución legal- con un importante margen de discrecionalidad en la asignación del recurso procedente en cada caso. 
- Red mixta de utilización pública. Superando definitivamente los prejuicios pasados, tras declarar entre los principios de la Ley la participación tanto del tercer sector como de la iniciativa privada en los servicios y prestaciones de promoción de la autonomía personal y atención a la situación de dependencia -art. 3.m) y $n$ )-, la Ley 39/2006 configura el SAAD como una red de utilización pública que integra, de forma coordinada, centros y servicios, públicos y privados -art. $6.2-{ }^{193}$.

- Universalización. Los sistemas de servicios sociales -tal como se ha puesto de manifiesto más arriba- debido a la escasez de las plazas públicas, se han caracterizado por imponer unos requisitos económicos extremos, que han dejado fuera de los sistemas a las clases medias. Ahora lo que se trata es de que en la asignación del recurso prime la necesidad del mismo. Así, la Ley 39/2006 declara la universalidad en el acceso de todas las personas en situación de dependencia, en condiciones de igualdad efectiva y no discriminación -art. 3.b)-. Así, el reconocimiento de la situación de dependencia depende exclusivamente de "la capacidad de la persona para llevar a cabo por sí misma las actividades básicas de la vida diaria, así como la necesidad de apoyo y supervisión para su realización por personas con discapacidad intelectual o con enfermedad mental" -art. 27.4-. Y, sobre todo, la Ley establece que la prioridad en el acceso a los servicios vendrá determinada por el grado y nivel de dependencia y, sólo a igual grado y nivel, por la capacidad económica del solicitante -art. 14.6-.

- Homologación de criterios. Frente a la diversidad de criterios a que han conducido los sistemas autonómicos, la Ley 39/2006 contempla un baremo común para valorar el grado y nivel de la dependencia ${ }^{194}$.

- Juridificación. Por lo anterior, es decir, debido una vez más a la escasez de plazas públicas el derecho de los ciudadanos a acceder a una plaza residencial era claramente claudicante. En cambio, el SAAD

\footnotetext{
${ }^{193}$ La Ley -art. 6.3- precisa que esta integración de los centros en el SAAD no supone "alteración alguna en el régimen jurídico de su titularidad, administración, gestión y dependencia orgánica”.
}

194 Por Real Decreto 504/2007, de 20 de abril, se aprueba el baremo de valoración de la situación de dependencia. 
pretende garantizar, al menos, el nivel mínimo de protección establecido por el Estado. Y si bien se establece escalonando en el tiempo la aplicación de la Ley, lo relevantes es que "el reconocimiento del derecho contenido en las resoluciones de las administraciones públicas competentes generará el derecho de acceso a los servicios y prestaciones correspondientes, a partir del inicio de su año de implantación de acuerdo con el calendario del fijado en la Ley o desde el momento de su solicitud de reconocimiento por el interesado, si ésta es posterior a esa fecha ${ }^{195}$. Hasta que la red de servicios esté totalmente implantada, las personas en situación de dependencia que no puedan acceder a los servicios por aplicación del régimen de prioridad señalado, tendrán derecho a la prestación económica -art. 14.7-.

- Validez estatal. El reconocimiento de la situación de dependencia se efectúa mediante resolución expedida por la Administración Autonómica correspondiente a la residencia del solicitante, pero a diferencia de lo que sucedía hasta ahora, esta resolución tendrá validez en todo el territorio del Estado -art. 28.2-. Así, en el supuesto de cambio de residencia, no es preciso volver a solicitar el reconocimiento de la situación de dependencia, sino que únicamente la Comunidad Autónoma de destino determinará, en función de su red de servicios y prestaciones, los que correspondan a la persona en situación de dependencia -art. 28.4-.

- Calidad. La Ley 39/2006 presta una especial atención a la calidad del SAAD, así se contempla tanto el establecimiento de estándares esenciales de calidad para cada uno de los servicios que conforman el Catálogo -art. 35.1-, como la fijación de criterios comunes de calidad y seguridad para la acreditación de los centros y servicios del Sistema -art. 34.2-.

\subsection{Determinaciones específicas sobre los centros residenciales para mayores}

Según la Ley 39/2006, el servicio de atención residencial ofrece, desde un enfoque biopsicosocial, servicios continuados de carácter personal y sanita-

\footnotetext{
${ }^{195}$ De acuerdo con la disposición final $1^{\underline{a}}$ de la Ley, la efectividad del derecho a las prestaciones de dependencia incluidas en la Ley se ejercitará progresivamente, de modo gradual y se realizará de acuerdo con un calendario que empieza el 1 de enero de 2007 y concluye el 2013. De este modo, las hasta ahora subvenciones discrecionales también cambiarán de naturaleza jurídica.
} 
rio $^{196}$. Este servicio se prestará en los centros residenciales habilitados al efecto según el tipo de dependencia, grado de la misma e intensidad de cuidados que precise la persona.

La prestación de este servicio puede tener carácter permanente, cuando el centro residencial se convierta en la residencia habitual de la persona, o temporal, cuando se atiendan estancias temporales de convalecencia o durante vacaciones, fines de semana y enfermedades o periodos de descanso de los cuidadores no profesionales. Asimismo, como viene sucediendo, se reconoce que el servicio de atención residencial será prestado por las Administraciones Públicas en centros propios y concertados ${ }^{197}$. Asimismo, la Ley precisa que las Comunidades Autónomas establecerán el régimen jurídico y las condiciones de actuación de los centros privados concertados -art. 16.2-. Además, añade que los centros y servicios privados no concertados que presten servicios para personas en situación de dependencia deberán contar con la debida "acreditación” de la Comunidad Autónoma correspondiente -art. 16.3-198, y esta exigencia plantea la duda de si son conformes con la misma los procedimientos autorizatorios que prevean el otorgamiento de la autorización por silencio estimatorio.

La intensidad del servicio de Atención Residencial estará en función de los servicios del centro que precisa la persona con dependencia, de acuerdo con su programa individual de atención ${ }^{199}$. Finalmente, la Ley 39/2006 establece que los centros residenciales para personas en situación de dependencia habrán de disponer de un reglamento de régimen interior, que regule su organización y funcionamiento, que incluya un sistema de gestión de calidad y que establezca la participación de los usuarios, en la forma que determine la Administración competente -art. 35.2-.

196 El Real Decreto 727/2007, de 8 de junio, declara, a su vez, que el servicio de Atención Residencial ofrece una atención integral y continuada, de carácter personal, social y sanitario -art. $10.1-$.

197 Hay no obstante un importante matiz, pues con independencia de que servicio se preste en un centro propio o concertado la Ley parece reconocer que, en ambos supuestos, el servicio es "prestado por las Administraciones Públicas".

198 Como puede verse, la Ley 39/2007 se refiere a la acreditación en un sentido diverso a la legislación autonómica, como la andaluza.

199 Art. 10.3 Real Decreto 727/2007, de 8 de junio. 


\subsection{La responsabilidad sancionadora en la Ley 39/2006 del Sistema para la Autonomía y Atención a Dependencia}

A diferencia de la Ley de Andalucía 2/1988 de Servicios Sociales, la Ley 39/2006 del SAAD contiene una ordenación mucho más precisa y de calidad técnica en materia sancionadora. Del catálogo de infracciones administrativas -art. 43-, salvo la referida a aplicar las prestaciones económicas a finalidades distintas, prácticamente todas las demás puede ser cometidas por los centros residenciales o su personal. Tales infracciones podemos diferenciarlas en dos tipos:

- Infracciones materiales, que suponen un lesión o riesgo para los derechos e intereses de los residentes: "Dificultar o impedir el ejercicio de cualesquiera de los derechos reconocidos en esta Ley"; "Tratar discriminatoriamente a las personas en situación de dependencia"; "Conculcar la dignidad de las personas en situación de dependencia"; y "Generar daños o situaciones de riesgo para la integridad física o psíquica”.

- Infracciones formales, que consisten en un incumplimiento de legalidad, con independencia de que pueda o no existir una lesión de los derechos e intereses de los residentes: "Obstruir la acción de los servicios de inspección"; "Negar el suministro de información o proporcionar datos falsos"; "Incumplir las normas relativas a la autorización de apertura y funcionamiento y de acreditación de centros de servicios de atención a personas en situación de dependencia"; e "Incumplir los requerimientos específicos que formulen las Administraciones Públicas competentes".

Hay, no obstante, algunos aspectos de la tipificación cuestionables. Así, por ejemplo, la consideración como infracción grave de las infracciones que comporten "Coacciones, amenazas, represalias o cualquier otra forma de presión ejercida sobre las personas en situación de dependencia o sus familias" -art. 44.3.c)-. A nuestro modo de ver, es difícil imaginar otro comportamiento más reprochable que el indicado sin caer de plano en las mallas del Código Penal, por lo que tal conducta debería haber sido calificada directamente como una infracción muy grave. Por el contrario, la circunstancia de atentar "gravemente contra los derechos fundamentales de la persona", como determinante de la calificación de una infracción como muy grave -art. 44.4.a)-, a nuestro modo de ver, adolece de una cierta indeterminación.

Por otro lado, en relación con las sanciones, la Ley 39/2006 contempla expresamente el cese temporal de la actividad o cierre del establecimiento, lo- 
cal o empresa para las empresas proveedoras de servicios -art. 45.1-, para las infracciones muy graves en los casos de especial gravedad, reincidencia de la infracción o trascendencia notoria y grave -art. 45.5-. Pero, sobre todo, la Ley $39 / 2006$ ha tenido el acierto de contemplar expresamente la posibilidad de que la Administración competente, durante la sustanciación del procedimiento por infracciones graves o muy graves, y ante la posibilidad de causar perjuicios de difícil o imposible reparación, pueda acordar, como medida cautelar, el cierre del centro o la suspensión de la actividad. No obstante, se echa en falta que tal medida cautelar pudiera ser adoptada con carácter previo a la incoación del procedimiento sancionador en caso de riesgo inminente o de lesión ya efectiva. Así, debe señalarse que la LRJPAC -art. 72.2-, tras la reforma operada por la Ley 4/1999, exige, con carácter general, que estas medidas previas al inicio del procedimiento se encuentren expresamente previstas en una norma con rango de Ley, si bien no existe dificultad alguna para que esta habilitación legal se contenga en las leyes autonómicas, como de hecho sucede en algún caso destacado 200 .

Finalmente, debe señalarse que, de acuerdo con la Ley 39/2006 -art. 11.1.f)-, corresponde a las Comunidades Autónomas en relación con Sistema para la Autonomía y Atención a la Dependencia, entre otros cometidos, "Inspeccionar y en su caso sancionar los incumplimientos sobre los requisitos y estándares de calidad de los centros y servicios y respeto de los derechos de los beneficiarios".

\section{BIBLIOGRAFÍA Y DOCUMENTACIÓN}

ALONSO SECO, J.M.: "El 'status' jurídico-administrativo del interno en centros de la red pública asistencial: derechos y obligaciones”, Documentación Administrativa, núm. 271, 2005, págs. 413-440.

\footnotetext{
${ }^{200}$ La Ley de Baleares 4/1999, de 31 de marzo, por la que se regula la Función Inspectora y Sancionadora en materia de Servicios Sociales, establece que, si en el curso de la inspección se aprecia razonablemente la existencia de riesgo inminente de daños o perjuicios graves para los usuarios, el Inspector actuante propondrá al órgano competente la adopción de las medidas cautelares o de precaución correspondientes. Pero, se añade, además: "En cualquier caso, podrá ordenar a los titulares o responsables de establecimientos de servicios sociales la adopción de las medidas provisionales que razonablemente sean imprescindibles para salvaguardar la salud y la seguridad de los usuarios, que habrán de ser confirmadas o rectificadas por el órgano competente" -art. 14-.
} 
ARARTEKO, "El año internacional de las personas mayores", Los derechos no caducan con la edad: el año internacional de las personas mayores., San Sebastián, 1999, pp. 9 y ss.

-Las Residencias de Tercera Edad en la Comunidad Autónoma Vasca”. Ed. Ararteko y SIIS. Vitoria-Gasteiz, 1994.

BELTRÁN AGUIRRE, J.L.: "La articulación de las Administraciones social y sanitaria en la atención integral a los dependientes: realidad actual y necesidades de futuro", en Organización y procedimientos administrativos, Aranzadi, Pamplona, 2007, pp. 337 y ss.

-"La ordenación jurídica de la atención y protección de los ancianos por las administraciones públicas", Los derechos no caducan con la edad: el año internacional de las personas mayores, San Sebastián, 1999, pp. 27 y ss.

BERNAL BLAY, M.A.: "La incidencia de la contratación pública en la gestión de los servicios sociales", Revista Aragonesa de Administración Pública, núm. 29, 2006, págs. 205-236.

CÁMARA DE CUENTAS DE ANDALUCÍA, Informe de Fiscalización de las Residencias de Mayores concertadas con el IASS, correspondiente al ejercicio 2002, BOJA núm. 108, de 6 de junio de 2005.

CENTRO DE DOCUMENTACIÓN Y ESTUDIOS, SIIS, Los derechos de los residentes y las especificidades del medio residencial ¿̇cómo compaginarlos?, San Sebastián, 2001.

-Sistemas de autorización y acreditación de servicios residenciales para ancianos, San Sebastián, 1991.

DE COUTO GÁLVEZ, R.: La Protección Jurídica de los Ancianos, Madrid 2006.

DEFENSOR DEL PUEBLO, Informes, estudios y documentos, La atención sociosanitaria en España: perspectiva gerontológica y otros aspectos conexos, Recomendaciones del Defensor del Pueblo e informes de la Sociedad Española de Geriatría y Gerontología y de la Asociación Multidisciplinaria de Gerontología, Madrid, 2000.

-Informes, estudios y documentos, Residencias públicas y privadas de la tercera edad, Madrid, 1990.

-Informes anuales a las Cortes Generales.

DEFENSOR DEL PUEBLO ANDALUZ, "Investigación sobre las Residencias de Ancianos Ilegales (queja de oficio 95/3788)", Informe anual al Parlamento de Andalucía, 1995.

-Informes anuales al Parlamento de Andalucía.

DEFENSOR DEL PUEBLO DE CASTILLA- LA MANCHA, "Personas mayores desatendidas: una realidad", 2005.

DEFENSORA DEL PUEBLO DE NAVARRA, Informe especial al Parlamento de Navarra "La atención a la dependencia de las personas mayores en Navarra”, marzo de 2005. 
DIPUTADO DEL COMÚN DE CANARIAS, "Diagnóstico de la situación de los centros para personas mayores en Canarias”, 2001.

IMSERSO, Guía 2004 de residencias para personas mayores en España, IMSERSO, 2004.

-Informe 2006, Las personas mayores en España, IMSERSO, 2006.

- “Informe de valoración del Plan Gerontológico Estatal. 1992-1997”. Ed. Ministerio de Trabajo y Asuntos Sociales. Instituto de Migraciones y Servicios Sociales. Madrid, 1999.

JUSTICIA DE ARAGÓN, Informe especial "Calidad de vida de las personas mayores. Un supuesto especial: el maltrato", Zaragoza, 2004.

FERNÁNDEZ RAMOS, S.: La actividad administrativa de inspección, Comares, Granada, 2002.

GARCÍA VILLALUENGA (Coord): El Derecho y los servicios sociales, Comares, Granada, 1997.

OSLÉ C.- ANAUT, S.: Los modelos de financiación pública de las residencias para personas mayores, Gobierno de Navarra, septiembre de 2004.

MARTÍnEZ MAROTO, A.: Diez temas juridicos de Portal de Mayores, IMSERSO, 2006.

MINISTERIO DE TRABAJO Y ASUNTOS SOCIALES, Libro Blanco de Atención a las personas en situación de dependencia en España, 2004.

MORENO REBATO, Mar: Régimen jurídico de la asistencia social, Ministerio de Trabajo y Asuntos Sociales, Madrid, 2002.

-"La protección de la tercera edad”, Documentación Administrativa, núm. 271, 2005, págs. 271-290.

ORTEGA ALVAREZ, L.: "Servicios públicos y usuarios de servicios", Documentación Administrativa, núm. 271, 2005, págs. 153-174.

PEMÁN GAVÍN, J.M.; "La asistencia social en España: delimitación conceptual y marco jurídico general”, págs. 39-80.

-"El marco jurídico de la asistencia social: competencias, modalidades y principios de la acción administrativa”, Revista Aragonesa de Administración Pública, núm. 23, 2003, págs. 41 y ss.

PROCURADOR DEL COMÚN DE CASTILLA Y LEÓN, "La atención residencial de la tercera edad en Castilla y León”, Boletín Oficial de las Cortes de Castilla y León, núm. 223, 16 de mayo de 1998.

SENADO, Informe de la Comisión de Relaciones con el Defensor del Pueblo y de los Derechos Humanos, sobre La situación de las residencias de la tercera edad en España y alternativas a las mismas desde la perspectiva actual, BOCG, Senado, III Legislatura, Serie I, núm. 326, 22 de junio de 1989, 1989.

-Informe de la Ponencia especial, constituida en el seno de la Comisión de Sanidad y Asuntos Sociales, para el "Estudio de la problemática del envejecimien- 
to de la población española", BOCG, Senado, VI Legislatura, Serie I, núm. 805, de 17 de diciembre de 1999.

SEOANE, C.- LUMBIERRES, C.: "Iniciativas privadas en la gestión de la acción social en Aragón”, Revista Aragonesa de Administración Pública, núm. 21, 2002, pp. 495 y ss.

SINDIC DE GREUGES DE CATALUNA, Informe extraordinario sobre la atención a las personas mayores dependientes en Cataluña, 2004.

SOTELO IGLESIAS, H.: "Algunas consideraciones acerca de los derechos de las personas ancianas en residencias", Los derechos no caducan con la edad: el año internacional de las personas mayores, San Sebastián, 1999, pp. 83 y ss.

TORNOS MAS, J.: "Efectividad de los derechos y exigibilidad de los servicios sociales", Documentación Administrativa, núm. 271, 2005, págs. 371-388.

-Los servicios sociales de atención a la tercera edad. El caso de Cataluña, Tirant lo Blanch, Valencia, 2002.

TRIBUNAL DE CUENTAS, "Informe de fiscalización de la gestión contractual realizada por las diputaciones provinciales, ejercicio 2002, respecto de los servicios de asistencia domiciliaria”, núm. 662, de 2005.

VALEDOR DO POBO, Informe extraordinario "Situación de los ancianos en Galicia”, junio 1994.

VAQUER CABALLERÍA, M.: "Las relaciones entre la protección social y la responsabilidad patrimonial de las Administraciones públicas", Documentación Administrativa, núm. 271, 2005, págs. 573 y ss.

VILLAR ROJAS, F.J.: "Formas de gestión de los servicios sociales: en particular, la vinculación de gestores privados al sistema público mediante conciertos y convenios", Documentación Administrativa, núm. 271, 2005, págs. $389-412$.

-"La concesión como modalidad de colaboración privada en los servicios sanitarios y sociales”, Revista de Administración Pública, núm. 172, 2007, págs. 141-188.

VV. AA.: La protección de la dependencia, Tirant lo Blanch, Valencia, 2007. 